\title{
Revisão e análise cladística de Serdia Stål (Heteroptera, Pentatomidae, Pentatomini) ${ }^{1}$
}

\author{
Nora Denise Fortes de Fortes ${ }^{2} \&$ Jocélia Grazia ${ }^{3,4}$
}

\begin{abstract}
${ }^{1}$ Contribuição $n^{o} .459$ do Departamento de Zoologia da Universidade Federal do Rio Grande do Sul. Tese apresentada ao Programa de PósGraduação em Ciências Biológicas, Área de Concentração em Entomologia - UFPR (Curitiba-PR) para o título de Doutor em Ciências Biológicas.

${ }^{2}$ Faculdade de Biologia. Universidade Luterana do Brasil, Rua Miguel Tostes 101, 92420-280 Canoas-RS, Brasil. noraento@terra.com.br

${ }^{3}$ Departamento de Zoologia, Instituto de Biociências; Universidade Federal do Rio Grande do Sul; Prédio 43435. Av. Bento Gonçalves 9500; 91501-970 Porto Alegre-RS, Brasil. jocelia@ufrgs.br

${ }^{4}$ Bolsista do CNPq.
\end{abstract}

\begin{abstract}
Review and cladistic analysis of Serdia Stål (Heteroptera, Pentatomidae, Pentatomini). Thirteen species are presently included in the genus: S. apicicornis Stål, 1860; S. beckerae Thomas \& Rolston, 1985; S. bihamulata, Thomas \& Rolston, 1985; S. calligera Stål, 1860; S. concolor Ruckes, 1958; S. costalis Ruckes, 1958; S. delphis Thomas \& Rolston, 1985; S. inspersipes Stål, 1860; S. limbatipennis Stål, 1860; S. lobata Thomas \& Rolston, 1985; S. quadridens Thomas \& Rolston, 1985; S. rotundicornis Becker, 1967, and S. ruckesi Thomas \& Rolston, 1985. Five new species are described: S.indistincta sp. nov. (Iraí; Rio Grande do Sul), S. bicolor sp. nov. (Ponta Grossa; Paraná) S. maculata sp. nov. (Itatiaia; Rio de Janeiro) S. maxima sp. nov. (Imbituba; Santa Catarina) and S. robusta sp. nov. (Itatiaia; Rio de Janeiro) from Brazil. A cladistic analysis was performed using 40 characters and 21 taxa. The genera Tibilis Stål, 1860; Neotibilis Grazia \& Barcellos, 1994 and Similliserdia Fortes \& Grazia, 1998 were used as outgroups. The monophyly of Serdia is supported by three synapomorphies: scutellum apex with darkned margins; males with the inner wall of genital cup thicker and with brim-shaped processes; females with the thickennings of the vaginal intima arising at posterior half of gonapophyses 9, and projected ventrad. The subgenus Brasiliicola Kirkaldy, 1909 is considered junior synonym of Serdia. Illustrations, a map of geographical distribution and a key for the species are also provided.
\end{abstract}

KEYWORDS. Cladistics; Neotropical; Pentatomidae; Serdia; taxonomy.

RESUMO. Revisão e análise cladística de Serdia Stål. (Heteroptera, Pentatomidae, Pentatomini). Treze espécies são hoje incluídas no gênero: S. apicicornis, Stål, 1860; S. beckerae Thomas \& Rolston, 1985; S. calligera Stål, 1860; S. concolor Ruckes, 1958; S. costalis Ruckes, 1958; S. delphis Thomas \& Rolston, 1985; S. inspersipes Stål, 1860; S. lobata Thomas \& Rolston, 1985; S. rotundicornis Becker, 1967 e S. ruckesi Thomas \& Rolston, 1985. Cinco novas espécies são descritas: S. indistincta sp. nov (Irai, Rio Grande do Sul), S. bicolor sp. nov (Ponta Grossa, Paraná), S. maculata sp. nov (Itatiaia, Rio de Janeiro), S. máxima sp. nov (Imbituba, Santa Catarina) e S. robusta sp. nov (Itatiaia, Rio de Janeiro) do Brasil. A análise cladística foi realizada usando 40 caracteres e 21 táxons. O gênero Tibilis Stål, 1860; Neotibilis Grazia \& Barcellos, 1994 e Similliserdia Fortes \& Grazia, 1998 foram usados como grupo-externo. A monofilia de Serdia foi sustentada por 3 sinapomorfias: ápice do escutelo com margens enegrecidas, machos com a parede da taça genital espessada com processos em aba, fêmeas com o espessamento da íntima vaginal situado na metade posterior das gonapófises 9 e projetando-se ventralmente. O subgênero Brasiliicola Kirkaldy, 1909 é considerado sinônimo junior de Serdia. São fornecidas ilustrações, mapas de distribuição geográfica e chave para as espécies.

PALAVRAS-CHAVE: Cladística, Neotropical, Pentatomidae, Serdia, Taxonomia.

Schuh \& Slater (1995) reconhecem 14 famílias em Pentatomoidea. As relações dentro desta superfamília estão sendo estudadas por Grazia \& Schuh (em preparação), que reconhecem 15 famílias das quais 11 têm ocorrência na região neotropical: Acanthosomatidae, Canopidae, Cydnidae, Cyrtocoridae, Corimelaenidae, Dinidoridae, Megarididae, Pentatomidae, Phloeidae, Scutelleridae e Tessaratomidae. A família Pentatomidae constitui um grupo monofilético, incluindo sete subfamílias (Grazia \& Schuh, em preparação). Estão representadas na região Neotropical as subfamílias Asopinae, Discocephalinae, Edessinae, Pentatominae e Stirotarsinae, esta última monotípica, proposta por Rider (2000). Discocephalinae, Edessinae e Stirotarsinae têm distribuição exclusiva nos neotrópicos. Cyrtocoridae, anterioremente tratada como subfamilia de Pentatomidae, adquiriu o status de familia em Packauskas \& Schaefer (1998) o que é corroborado por Grazia \& Schuh (em preparação).

A família Pentatomidae é uma das quatro maiores de Heteroptera, com aproximadamente 760 gêneros e mais de 4100 espécies amplamente distribuídas por todas as maiores regiões biogeográficas, principalmente a região Neotropical. Pentatominae é a maior subfamília com aproximadamente 2.800 espécies reunidas em 526 gêneros e apresenta como características básicas os ângulos umerais frequentemente desenvolvidos e o escutelo nunca atingindo o ápice do abdome. Com ampla distribuição mundial, está subdividida em 9 tribos (Schuh \& Slater 1995, Grazia et al. 1999). Destas, 3 ocorrem na região neotropical. Novas propostas de classificação, a nível de tribo num contexto mundial, vêm sendo utilizadas em catálogos regionais (Cassis \& Gross 2002). Rider (informação 
pessoal) reconhece 44 tribos (mais 39 gêneros não definidos). A tribo Pentatomini (sensu Schuh \& Slater 1995, Grazia et al. 1999) é a mais diversa da subfamília, contendo 405 gêneros e 2.208 espécies. Na região neotropical a tribo Pentatomini compreende hoje 108 gêneros e 544 espécies. Da totalidade dos gêneros, menos da metade foi revisada; no século XX mais de 40 gêneros neotropicais foram descritos.

A utilização de uma metodologia baseada na morfologia da genitália de ambos os sexos e análise cladística das espécies torna-se, então, um instrumento precioso para o avanço nos trabalhos de revisão de pentatomídeos neotropicais.

Apesar das dificuldades para a realização destes estudos, seja por falta de material ou ausência de dados a respeito da ocorrência das espécies, alguns autores que trabalham com fauna neotropical (Grazia, 1978; Thomas Jr. \& Yonke, 1985, Grazia, 1997, Barcellos \& Grazia, 2003 e Campos \& Grazia, no prelo) introduziram em seus trabalhos a metodologia cladística para as espécies, gêneros ou grupos de gêneros de Pentatomini.

O gênero Serdia foi descrito por Stål (1860) para incluir quatro espécies provenientes do Rio de Janeiro. O autor dividiu o gênero em dois grupos: grupo A, espécie com ângulos laterais do tórax em forma de "cornos" - S. apicicornis; grupo B, espécies sem ângulos laterais do tórax proeminentes - $S$. calligera, S. inspersipes e S. limbatipennis.

Stål (1867), na chave para os pentatomídeos americanos, incluiu Serdia no grupo que apresentava mesosterno carenado, metasterno elevado e emarginado para encaixe do tubérculo basal do abdome e jugas obtusas; e, ainda, comparou Serdia aos gêneros Tibilis Stål, 1860 e Taurocerus Amyot \& Serville, 1843. Stål (1872) propôs um novo arranjo incluindo em dois grupos as suas quatro espécies, levando em consideração a forma da cabeça e a face ventral do abdome: grupo a, com as espécies $S$. apicicornis, $S$. inspersipes e $S$. limbatipennis e o grupo aa, S. calligera.

Lethierry \& Severin (1893) incluíram as quatro espécies de Stål, 1860 em seu catálogo de Heteroptera.

Kirkaldy (1909) considerou o grupo a de Stål (1872) como subgênero $S$. (Serdia) designando $S$. apicicornis como espécie-tipo e propôs, para o grupo aa o novo subgênero $S$. (Brasiliicola) com $S$. calligera como espécie-tipo.

Kormilev (1955) aproximou Adoxoplatys Breddin, 1903 de Serdia mas não apresentou uma diagnose.

Kormilev (1956) descreveu três novas espécies: S. vianai, S. stali e $S$. bergi dentro do gênero Serdia por sua semelhança com S. limbatipennis. Porém Ruckes (1958a), depois de comparar as três espécies com outras espécies de Serdia, transferiu-as para a tribo Halyini criando o gênero Zimmeria para incluí-las. Ruckes (1958b) descreveu duas novas espécies de Serdia provenientes do Brasil: S. concolor e S. costalis.

Buckup (1961) registrou a presença de $S$. (Brasiliicola) calligera e $S$. (Serdia) limbatipennis para o Rio Grande do Sul.

Becker (1967) revisou o gênero, redescrevendo as espécies de Stål (1860) e Ruckes (1958b) e adicionou S. rotundicornis como uma nova espécie. Providenciou, também, uma chave para os subgêneros e para as espécies.
Becker \& Grazia-Vieira (1971), estudando o material da Venezuela, registraram a presença de $S$. (S.) concolor.

Rolston et al. (1980) propuseram a divisão dos pentatomídeos americanos em três seções e incluiram Serdia na seção três de Pentatomini que reúne os gêneros que possuem um espinho mediano na base ventral do abdome, em oposição à carena do metasterno.

Froeschner (1981) descreveu o gênero Elsiella e aproximou-o de Serdia pela estrutura do pro-, meso- e metasterno, e separou os dois gêneros pelo comprimento do $2^{\circ}$ artículo antenal, que em Serdia corresponde a menos da metade do comprimento do $3^{\circ}$ artículo antenal e em Elsiella mede $4 / 5$ do comprimento do $3^{\circ}$ artículo antenal. Distinguiu os dois gêneros também pela estrutura da área evaporatória metapleural e pela coloração.

Linck \& Grazia-Vieira (1983 e 1987) em seus trabalhos sobre pentatomídeos capturados em armadilha de luz em Santa Maria (RS- Brasil), registraram S. (B.) calligera, S. (S.). concolor e Serdia $\mathbf{s p .}$

Grazia (1984) complementando a referência feita a $S$.(S.) concolor em Becker \& Grazia-Vieira (1971), apresentou os dados do tipo, incluindo a localidade-tipo.

Thomas \& Rolston (1985) descreveram seis novas espécies (S. ruckesi, S. quadridens, S. lobata, S. delphis, S. beckeri e S. bihamulata) incluindo-as no subgênero S. (Serdia); apresentaram, também, uma chave dicotômica, modificada de Becker (1967), para os dois subgêneros.

Ainda, Grazia \& Barcellos (1994) ao descreverem Neotibilis, distinguiram de Serdia pela forma do peritrema ostiolar em ruga alongada, levemente curvada em direção anterior; em Serdia o peritrema é curto e de ápice digitiforme.

Fortes \& Grazia (1998) ao descreverem Similliserdia, consideraram-no semelhante a Serdia pelo seu fácies, distinguindo-o de Serdia pelo mesosterno sulcado, terço anterior da carena metasternal afilada e presença de sensilas basicônicas no pigóforo.

O gênero Serdia reúne atualmente 18 espécies, das quais cinco estão sendo propostas neste trabalho, com distribuição desde a Costa Rica até o sul do Brasil e norte da Argentina sendo que a grande maioria das espécies está concentrada na região Sul e Sudeste do Brasil. Dados ecológicos e biológicos praticamente inexistem na bibliografia. O dimorfismo sexual está presente em $S$. limbatipennis, $S$. apicicornis e $S$. maxima.

Neste trabalho o gênero Serdia é revisado e são descritas as espécies conhecidas, as fêmeas inéditas de $S$. beckerae e $S$. costalis e cinco espécies novas; uma hipótese de parentesco entre as espécies do gênero, utilizando a metodologia cladística, é apresentada contribuindo assim para os estudos em Pentatomini.

\section{MATERIAL E MÉTODOS}

Foi examinado um total de 353 exemplares, inclusive os exemplares-tipo de todas as espécies. Os exemplares foram obtidos de coleções do Brasil e exterior, listadas a seguir, juntamente com o nome do curador e/ou responsável pelo empréstimo. As siglas seguem ARNETT, 1993. AMNH - 
American Museum of Natural History, New York, EUA (R.T. Schuh); BMNH - The Natural History Museum, London, UK (M. Webb); CASM - Chicago Academy of Sciences, Museum of Natural History, Illinois, EUA (D. A. Rider); DARC - Coleção particular de D.A. Rider, North Dakota University, North Dakota, EUA; DZUP - Coleção de Entomologia Pe. Jesus Santiago Moure, Departamento de Zoologia, Universidade Federal do Paraná, Curitiba, Brasil (L. Marinoni); FIOC Fundação Instituto Oswaldo Cruz, Rio de Janeiro, Brasil (J. Jurberg); IZAV - Instituto de Zoologia Agrícola, Universidad Central de Venezuela, Maracay, Venezuela (E. Osuna); LACM - Los Angeles County Museum of Natural History, California, EUA (J.P. Donahue); MACN - Museo Argentino de Ciencias Naturales "Bernardino Rivadavia" Buenos Aires, Argentina, (A. Bachmann); MNCE - Museu de História Natural Capão da Embuia, Curitiba, Paraná, Brasil (M. Miretzki); MCNZ - Museu de Ciências Naturais, Fundação Zoobotânica do Rio Grande do Sul, Porto Alegre, Brasil (H. Gastal); MNRJ - Museu Nacional, Rio de Janeiro, Brasil (M.A .Monné); MPEG - Museu Paraense Emílio Goeldi, Belém, Brasil (A .Harada); MZSP Museu de Zoologia, Universidade de São Paulo, São Paulo, Brasil (F. DuVal); NHRS - Naturhistoriska Ricksmuseet, Sektionen für Entomologi, Estocolmo, Suécia (Per Lindskog); UFRG - Departamento de Zoologia, Universidade Federal do Rio Grande do Sul, Porto Alegre, Brasil (J. Grazia); NMNH National Museum of Natural History, Washington D.C., EUA (R.C. Froeschner); ZMHB - Museum für Naturkunde der Humboldt Universitat, Berlim, Alemanha (J. Deckert).

Foram tomadas medidas de dez parâmetros morfométricos, sendo calculados média, amplitude e desvio padrão para machos e fêmeas de todos os exemplares, sempre que disponíveis. As medidas foram obtidas da seguinte forma: comprimento total, do ápice da cabeça ao ápice do $7^{\circ}$ segmento; comprimento da cabeça, do pronoto e do escutelo ao longo da linha mediana longitudinal; comprimento dos artículos antenais; largura da cabeça ao nível dos olhos; largura anterior do pronoto ao nível dos dentículos dos ângulos ântero-apicais; largura posterior do pronoto ao nível dos ângulos umerais, largura do escutelo junto aos ângulos basais, largura abdominal ao nível do terceiro segmento. Todas as medidas foram efetuadas na vista dorsal e estão apresentados em milímetros.

Os machos de $S$. costalis e $S$. robusta bem como as fêmeas de S. costalis e S. delphis, por se tratarem de material-tipo ou exemplares únicos, não foram dissecados.

A nomenclatura para as peças da genitália segue Dupuis $(1955,1970)$. Os desenhos de phallus de todas as espécies foram feitos apenas na vista lateral, porque a phallotheca é fortemente recurvada e dificulta a visualização dos processos da vésica nas vistas dorsal e ventral. Apenas o phallus de $S$. ruckesi foi desenhado em vista ventral e dorsal para ilustrar a forma da placa basal.

Na redescrição das espécies conhecidas foram enfatizados os caracteres diagnósticos e acrescidos outros não observados pelos autores originais, em especial da morfologia da genitália de ambos os sexos.

A ordem das descrições das espécies segue o cladograma.
Para a análise cladística, levantou-se 40 caracteres (três multiestados), de morfologia geral e de genitália, para um total de 21 táxons analisados (18 espécies de Serdia e três grupos externos). Os caracteres foram plotados numa matriz de dados (Tabela I), onde o número " 0 " (zero) indica o estado plesiomórfico de um caráter e os números " 1 " (um) até "3" (três) indicam os estados apomórficos do caráter, o símbolo “?” (ponto de interrogação) indica o caráter não observado. Os caracteres multiestado foram tratados como não ordenados por não ter sido possível, estabelecer a série de transformações dos caracteres. Autapomorfias não foram incluídas na matriz de dados, evitando sua influência nos índices de consistência e retenção.

A fim de levantar hipóteses de parentesco entre as espécies de Serdia foi utilizado a metodologia cladística (Hennig 1966; Eldredge \& Cracraft 1980; Wiley 1981; Amorin 1997). A polarização dos caracteres foi efetuada através do método de comparação com grupos-externos (Watrous \& Wheeler 1981; Nixon \& Carpenter 1993). Como tais, foram utilizados os gêneros Tibilis Stål, 1860 Neotibilis Grazia \& Barcellos, 1994 e Similliserdia Fortes \& Grazia, 1998. Os critérios utilizados para a escolha destes táxons foram a história taxonômica e análise prévia de caracteres morfológicos. O primeiro critério justificase no fato do gênero Tibilis ter sido citado como próximo a Serdia por Stål (1867) em sua chave dicotômica e por Becker (1967) no seu trabalho de revisão. Já o gênero Neotibilis, foi citado como próximo a Tibilis e Serdia por Grazia \& Barcellos (1994) e Similliserdia foi citado como próximo a todos estes gêneros pelo seu fácies Fortes \& Grazia (1998). Outro critério foi à semelhança de algumas estruturas de Tibilis, Neotibilis e Similliserdia, homólogas a estruturas encontradas em várias espécies de Serdia.

Para a análise dos caracteres no grupo externo utilizou-se a espécie-tipo de cada gênero. Para efetuar a análise utilizouse o programa para microcomputador Henig86 (Farris 1988). Utilizou-se o algoritmo ie*, o qual apresenta a maior garantia de obtenção dos cladogramas mais parcimoniosos, para processar a matriz de dados. São fornecidos o número de passos e os índices de consistência (ic) e retenção (ir) para o cladograma resultante, bem como para cada caráter. Para a discussão dos caracteres e do cladograma foi utilizada a notação "grupo " " (Amorin 1982). Na discussão do cladograma foi utilizado entre parênteses o número do caráter e o número do estado subescrito.

\section{RESULTADOS E DISCUSSÃO}

\section{Caracteres:}

Após os caracteres, são indicados o índice de consistência (ic) e índice de retenção (ir).

1) Contorno da cabeça diante dos olhos: 0 . triangular; 1. quadrangular ( $\mathrm{ic}=100, \mathrm{ir}=100$ )

$O$ gênero apresenta dois padrões de contorno da cabeça perfeitamente observados quando traçamos uma linha imaginária tangencial ao limite anterior aos olhos e outra de 


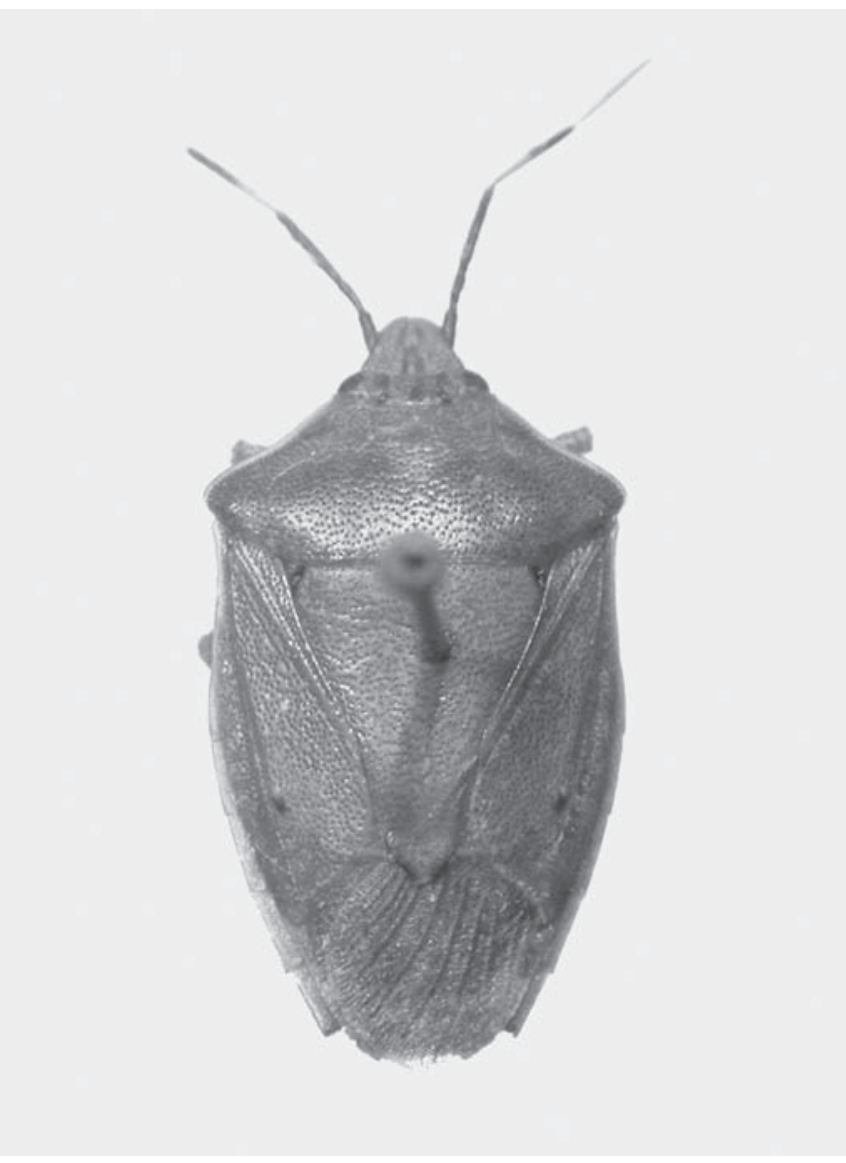

Fig. 1. Serdia indistincta, sp. nov. macho, $13 \mathrm{~cm}$.

cada lado da cabeça. Quando as linhas formam com o ângulo basal um ângulo de aproximadamente $45^{\circ}$ define-se o formato triangular (Figs 96, 97). Se as linhas laterais formam um ângulo de aproximadamente $90^{\circ}$ define-se o formato quadrangular (Fig. 98), uma sinamoporfia para o grupo $S$. costalis ${ }^{+}$.

2) Terço apical das jugas diante do clípeo: 0. levemente sobrepostas; 1 . justapostas $(\mathrm{ic}=33, \mathrm{ir}=66)$.

$\mathrm{O}$ terço apical das jugas apresenta-se sempre convergente para as espécies do gênero, podendo ser sobrepostas (Figs. 96,98 ) com a margem interna de uma das jugas levemente cobrindo a margem interna da outra juga. Jugas justapostas e não se tocando em toda a sua extensão, deixando o terço apical afastado formando um pequeno "V" aberto (Fig. 97) é uma sinapomorfia do grupo $S$. beckerae ${ }^{+}+S$. bihamulata $^{+}$ embora esteja presente em Tibilis. A ausência da condição apomórfica no grupo $S$. costalis ${ }^{+}$pode ser hipotetizada como perda secundária.

3) Comprimento do $2^{\circ}$ artículo antenal: 0 . com $1 / 2$ ou mais do comprimento do $3^{\circ}$ artículo antenal; $1.1 / 3$ ou menos do comprimento do $3^{\circ}$ artículo antenal(ic $=100$, ir $\left.=100\right)$.

O $2^{\circ}$ artículo antenal pode ter, geralmente, a metade ou mais do comprimento do $3^{\circ}$ artículo antenal (Fig. 100). O $2^{\circ}$ artículo antenal medindo $1 / 3$ ou menos do comprimento do $3^{\circ}$ artículo antenal (Figs. 99, 101, 102) é uma sinapomorfia para os gêneros Similliserdia e Serdia.

4) Sulco longitudinal na superfície dorsal do $3^{\circ}$ artículo antenal: 0 . ausente; 1 . presente $(\mathrm{ic}=50, \mathrm{ir}=75)$

Presença de um sulco longitudinal (Fig. 98) na superfície dorsal que pode se estender por quase todo o $3^{\circ}$ artículo. Corrobora a monofilia do grupo S. lobata ${ }^{+}$e surge independentemente em $S$. bicolor.

5) Forma do $4^{\circ}$ artículo antenal: 0 . cilíndrico; 1 achatado(ic $=$ 33 , ir=66).

$\mathrm{O} 4^{\circ}$ artículo antenal pode ser cilíndrico (Fig. 101) como os demais artículos ou achatado dorso-ventralmente (Fig. 102), sendo que esta condição é sinapomórfica para o grupo $S$. bihamulata $^{+}$, reverte em S. bicolor ${ }^{+}$com surgimento independente em $S$. lobata ${ }^{+}$.

6) Primeiro artículo do rostro: 0. não contido totalmente nas búculas (Fig. 105); 1. contido totalmente nas búculas(ic= $100, \mathrm{ir}=100)$.

O primeiro artículo do rostro com comprimento igual ou sutilmente menor que o comprimento das búculas (Figs. 103, 104) e totalmente contido nestas é uma sinamoporfia para os gêneros Similliserdia e Serdia.

7) Margens ântero-laterais do pronoto: 0 lisas; 1. crenuladas $(\mathrm{ic}=33$, ir=66).

$\mathrm{O}$ pronoto pode apresentar as margens ântero-laterais totalmente íntegras e lisas (Fig. 106), enrrugadas (Fig. 107) ou crenuladas. O estado derivado surge independentemente no grupo $S$. bicolor ${ }^{+}$e em $S$. quadridens revertendo no grupo $S$. costalis ${ }^{+}$.

8) Ângulos umerais: 0. não desenvolvidos; 1. desenvolvidos $(\mathrm{ic}=33$, ir $=33)$.

Os ângulos umerais desenvolvidos em amplas projeções dirigidas ântero-lateralmente, ápice arredondado de comprimento maior que a distância entre os olhos surge independentemente em $S$. rotundicornis, no clado $S$. maxima ${ }^{+}$ e em $S$. lobata com reversão no grupo $S$. costalis $^{+}$(Fig. 108). Este resultado claramente não confirma a proposta de STÅL (1860) de separar o gênero em dois grupos de espécies baseado na ausência ou presença de ângulos umerais desenvolvidos.

9) Calos posteriores a fóvea nos ângulos basais do escutelo: 0 . ausente; 1 . presente $(\mathrm{ic}=50, \mathrm{ir}=66)$.

$\mathrm{O}$ escutelo geralmente apresenta apenas fóveas negras nos ângulos basais (Figs. 108, 110), porém podem ocorrer 1+1 calos alaranjados, posteriores às fóveas (Fig. 109), circundados por pontuações castanho-escuras que corrobora o parentesco em S. costalis ${ }^{+}$, e surge independentemente em Neotibilis.

10) Margem laterais apicais do escutelo: 0. não refletidas; 1. refletidas $(\mathrm{ic}=100, \mathrm{ir}=100)$. 

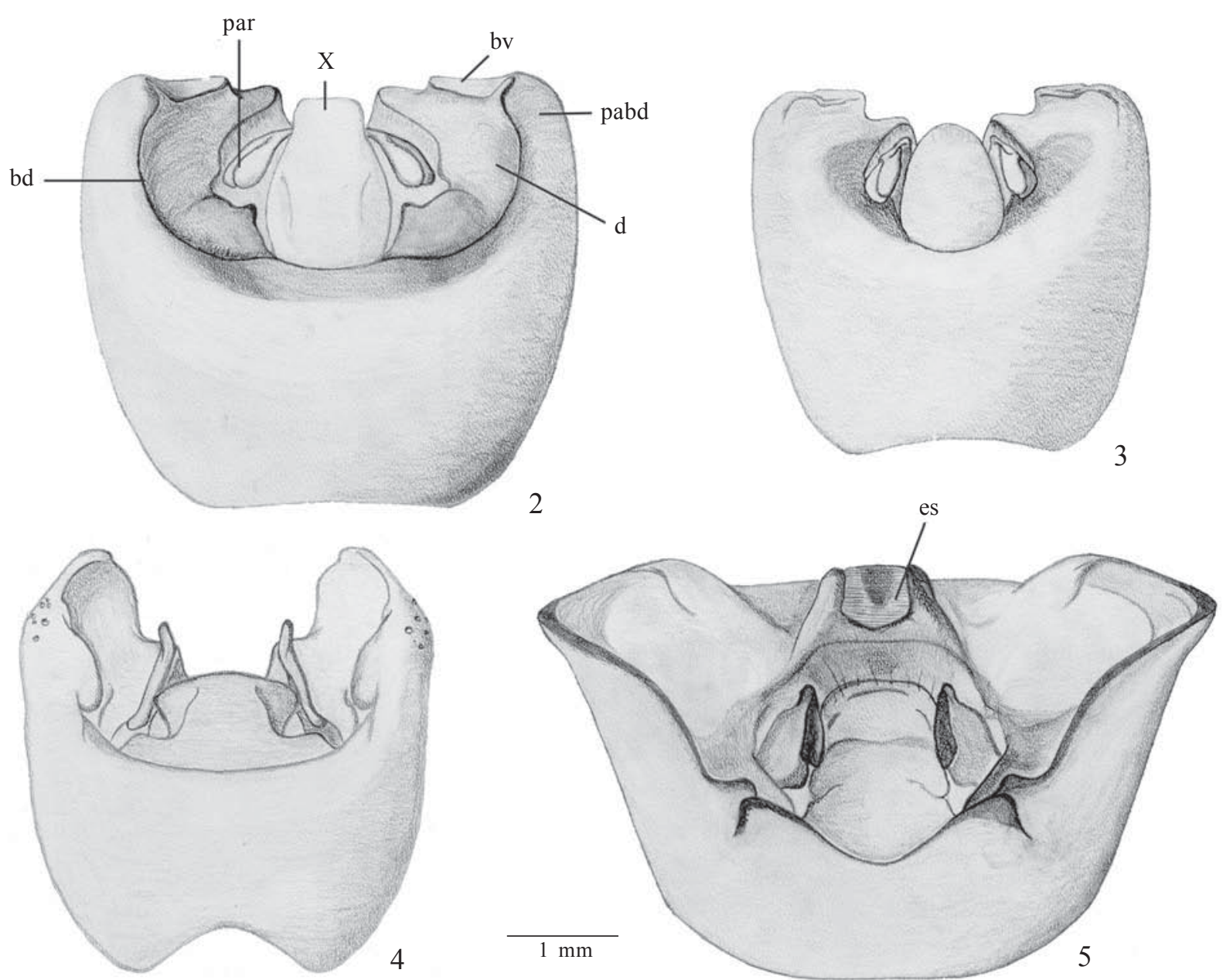

Figs. 2-5. Pigóforos, em vista dorsal. 2, Serdia concolor; 3, S. indistincta, sp. nov.; 4, S. inspersipes; 5, S. robusta, sp. nov.; bd=bordo dorsal, $\mathrm{bv}=$ bordo ventral, $\mathrm{d}=$ =diafragma, es=estrias, pabd=processo apical do bordo dorsal, par=parâmeros, $\mathrm{X}=$ =décimo segmento.

O escutelo com margens laterais do ápice levemente refletidos é uma sinapomorfia para o grupo S. inspersipes ${ }^{+}+$ S. robusta .

11) Coloração do ápice do escutelo: 0 . clara; 1 . enegrecida $(\mathrm{ic}=50, \mathrm{ir}=75)$.

O ápice do escutelo levemente delineado de negro (Figs. $108,109)$ é uma sinapomorfia para Serdia, sofrendo uma reversão em $S$. delphis + S. ruckesi.

12) Forma do peritrema ostiolar: 0 não auricular; 1. auricular (ic $=100$, ir $=100$ ).

A forma do peritrema ostiolar varia bastante dentro da tribo Pentatomini podendo ser não auricular em ruga alongada (Fig. 112) acompanhando a margem anterior da metapleura e progressivamente estreitado em direção ao ápice ou curto e auricular (Fig. 111) este, uma sinamoporfia para Serdia e Similliserdia.

13) Manchas escuras dos segmentos do conexivo: 0 . ausente; 1 . presente $(\mathrm{ic}=100, \mathrm{ir}=100)$ :
Os segmentos do conexivo apresentam-se, em geral, imaculados (Fig. 109 e 110) para a maioria das espécies de Serdia. Presença de manchas escuras, quase negras (Fig. 108), visíveis a olho nú e dispostas nos ângulos laterais anteriores e posteriores de cada segmento é a condição sinapomórfica para $S$. maxima e S. apicicornis.

14) Espinho mediano do $3^{\circ}$ segmento abdominal: 0. em ângulo agudo; 1 . em ângulo reto ou obtuso ( $\mathrm{ic}=50, \mathrm{ir}=83$ ).

O ângulo formado pelo encontro de duas retas imaginárias paralelas às margens laterais do espinho mediano do $3^{\circ}$ segmento abdominal pode ser menor que $90^{\circ}$ (Fig. 114) denominado de agudo. O ângulo medindo $90^{\circ}$ ou mais é denominado de reto (Fig. 113) ou obtuso e representa uma sinapomorfia para o grupo $S$. limbatipennis ${ }^{+}$com reversão no grupo $S$. costalis ${ }^{+}$.

15) Máculas calosas ventrais do abdome: 0 . ausente; 1 . presente $(\mathrm{ic}=100, \mathrm{ir}=100)$.

O clado S. costalis ${ }^{+}$apresenta uma série contínua de máculas calosas ventrais, lisas e lúteas, formando dois 

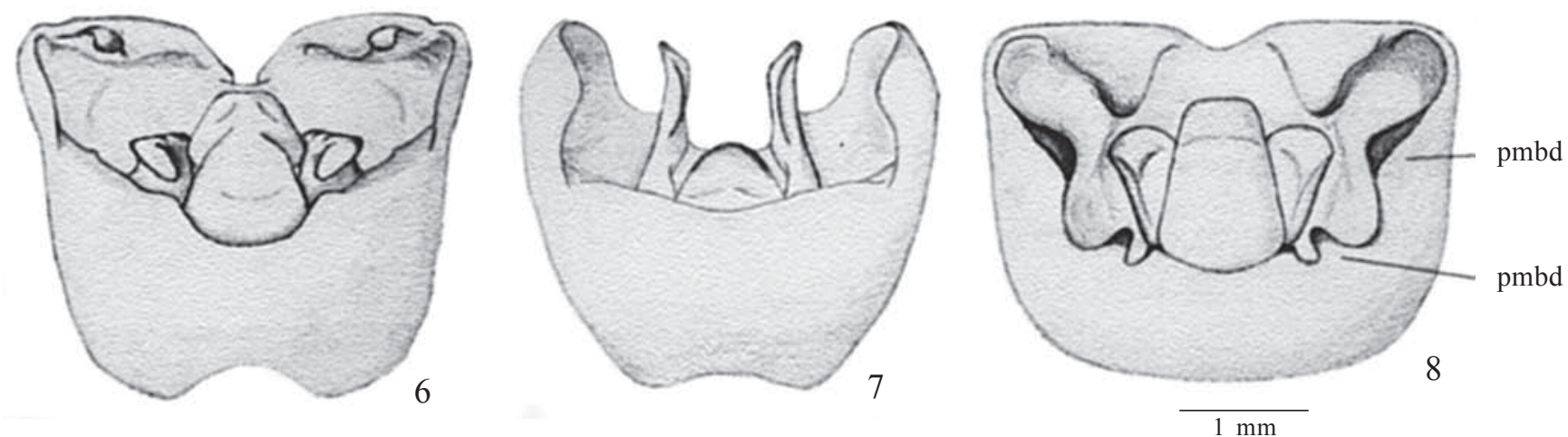

Figs. 6-8. Pigóforos, em vista dorsal. 6, Serdia bihamulata; 7, S. rotundicornis; 8, S. limbatipennis; pmbd=processo mediano do bordo dorsal.

semicírculos por urosternito (Fig. 115) voltados para o espiráculo; sendo uma condição sinapomórfica para o grupo.

16) Manchas negras ventrais situadas medianamente no $7^{\circ}$ esternito abdominal dos machos: 0 . ausente; 1 . presente (ic $=100$, ir $=100$ ).

Os machos do clado S. maxima + S. apicicornis são os únicos que apresentam manchas negras situadas medianamente no $7^{\circ}$ esternito abdominal, constituindo numa sinapomorfia para este grupo. 50 ).

17) Forma do corpo: 0. arredondado; 1 . ovalado (ic $=20$, ir $=$

Dois padrões de forma do corpo, ovalado ou arredondado são obtido a partir da medida do ângulo formado entre duas retas imaginárias, tangenciais às margens laterais do $7^{\circ}$ segmento abdominal. Para um ângulo menor que $45^{\circ}$ caracterizou-se a forma ovalada (Fig. 116) e para um ângulo maior ou igual a $45^{\circ}$ caracterizou-se a forma arredondada (Fig. 117). O estado derivado surgiu independentemente em Tibilis e nos grupos $S$. quadridens ${ }^{+}, S$. rotundicornis ${ }^{+}$e, revertendo em $S$. inspersipes + S. robusta e S. calligera.

18) Tufo de pêlos na parede ventral do pigóforo junto aos ângulos póstero-laterais: 0 . ausente; 1 . presente $(\mathrm{ic}=50, \mathrm{ir}=$ 75).

A presença de pêlos sobre a superfície ventral do pigóforo geralmente se dá de forma esparsa e uniforme. Porém, pode ocorrer um tufo de pêlos curvados e mais resistentes à remoção junto aos ângulos póstero-laterais (Fig. 118). O estado derivado surge independentemente em Similliserdia e no clado $S$. beckerae ${ }^{+}$.

19) Processos do ápice do bordo dorsal do pigóforo: 0 . Ausente (Figs. 119, 127; 1. presente $(\mathrm{ic}=50$, ir=66).

$\mathrm{O}$ bordo dorsal pode apresentar processos arredondados junto aos ângulos póstero-laterais do pigóforo (Figs. 2, 3, 17, 18 ) e surge independentemente nos clados $S$. concolor $+S$. indistincta e $S$. calligera + S. maculata.
20) Processos do terço mediano do bordo dorsal do pigóforo: 0. Ausente (Fig. 123); 1. presente $(\mathrm{ic}=25$, ir $=62$ ).

Processos pares (Figs. 4, 5, 8 a 12, 13, 16 a 18), situados nas regiões laterais ou nos limites do terço mediano do pigóforo em expansões arredondadas ou digitiformes que se projetam em direção ao $10^{\circ}$ segmento surgem independentemente no clado $S$. beckerae ${ }^{+}$e no clado $S$. limbatipennis ${ }^{+}$com reversão em $S$. apicicornis e S. lobata.

21) Processos da parede da taça genital: 0 . ausente; 1. presente $(\mathrm{ic}=100, \mathrm{ir}=100)$.

A parede da taça genital bastante espessada (Figs. 2 a 18) e formando processos em abas, muitas vezes escurecidas é uma sinapomorfia para Serdia.

22) Bordo ventral do pigóforo: 0. não projetado dorsalmente; 1 . projetado dorsalmente $(\mathrm{ic}=33, \mathrm{ir}=33)$.

O bordo ventral do pigóforo pode projetar-se amplamente em direção dorsal (Figs. 2, 3, 6, 8) e surge independentemente no grupo $S$. concolor ${ }^{+}$e nas espécies $S$. bihamulata e $S$. limbatipennis. Em S. bihamulata está presente um par de projeções digitiformes longas, denominadas hâmulus por Thomas \& Rolston (1985), representando uma autapomorfia para esta espécie (Fig. 6).

23) Folheto superior do bordo ventral do pigóforo, medianamente: 0. sem projeção (Figs. 120, 124); 1. com uma projeção; 2 . com $1+1$ projeções (ic $=28$, ir $=50$ ):

O folheto superior do bordo ventral do pigóforo com uma única projeção voltada posteriormente (Figs. 19, 20), é uma sinapomorfia para o grupo $S$. concolor ${ }^{+}$. O folheto superior com $1+1$ projeções, em geral convergentes ou orientadas posteriormente (Figs. 26 a 29, 128) é uma sinapomorfia para Similliserdia e Serdia com uma reversão em S. ruckesi e no grupo $S$. rotundicornis ${ }^{+}$.

24) Bordo ventral do pigóforo, medianamente: 0 . sem estrias; 1 . com estrias (ic $=100, \mathrm{ir}=100$ ).

Entre o folheto superior do bordo ventral, no vértice da escavação mediana pode ocorrer uma série de rugas 

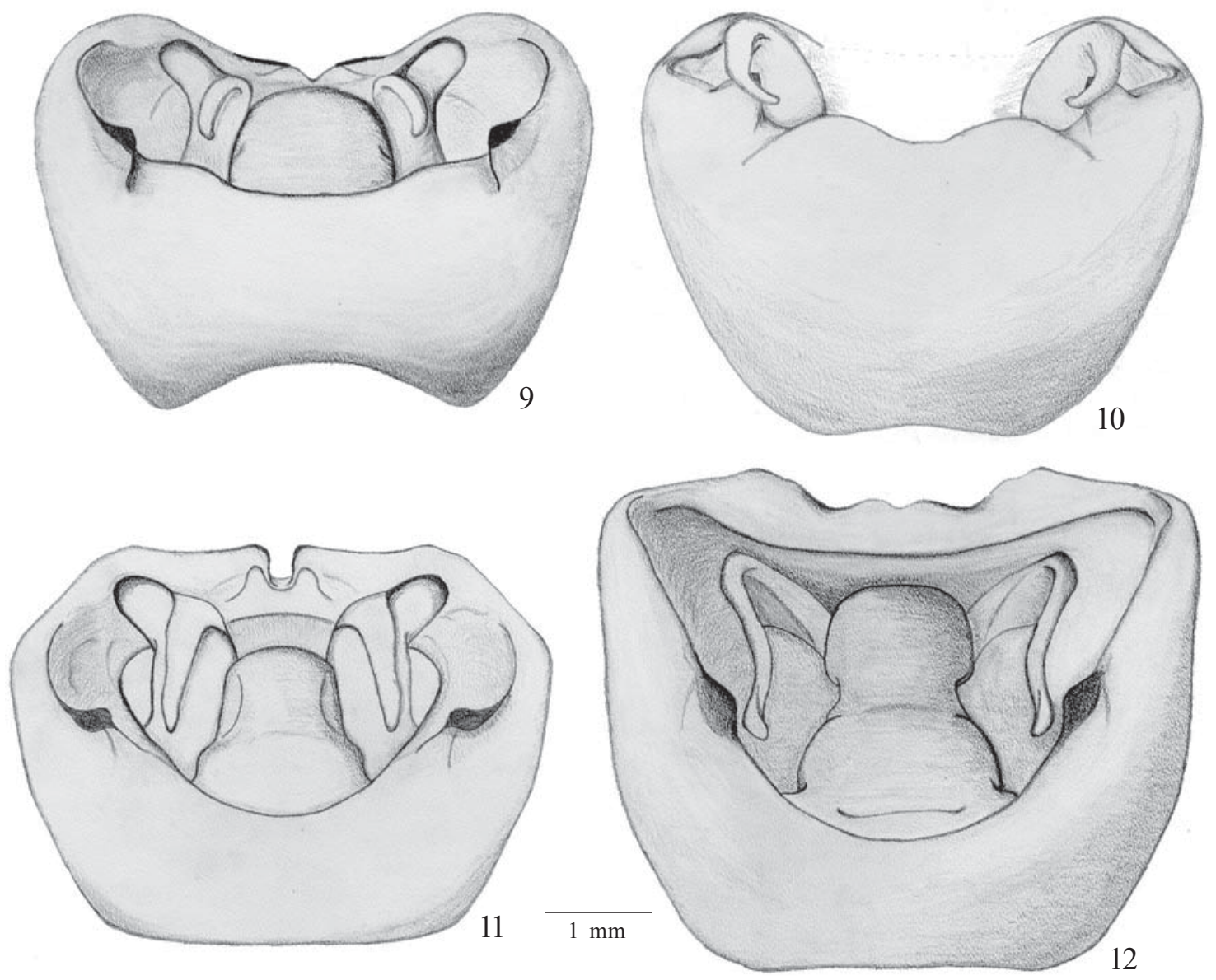

Figs. 9-12. Pigóforos, em vista dorsal. 9, Serdia beckerae; 10, S. quadridens (10º segmento omitido); 11, S. delphis; 12, S. ruckesi.

tranversais paralelas entre si e enegrecidas (Figs. 5, 14, 15, 33 a 35$)$ que representam uma sinapomorfia para o grupo $S$. rotundicornis ${ }^{+}$.

25) Parâmeros: 0. padrão $1 ; 1$. padrão $2 ; 2$. padrão $3 ; 3$. padrão 4 (ic $=60$, ir= 87$)$.

O padrão 1 se caracteriza por parâmeros pequenos de formato subquadrangular e com uma ou duas projeções digitiformes, voltadas para o mesmo lado, (Figs. 36, 37, 47, 121, $125,129)$. O padrão 2 se caracteriza por parâmeros delgados com uma projeção extremamente longa e curva (Figs. 42 a 45) sendo uma sinapomorfia para o grupo S. beckerae ${ }^{+}$. Parâmeros mais longos, de formato subcilíndrico com uma ou duas projeções (Figs. 38 a 41, 46 e 48), estas orientadas uma para a outra ou em sentidos opostos caracterizam o padrão 3, sinapomórfico para o grupo $S$. bihamulata ${ }^{+}$com uma reversão em S. apicicornis. O padrão 4 é caracterizado por parâmeros largos (Figs. 49 e 50), deprimidos lateralmente e com uma projeção perpendicular ao ápice do parâmero, sinapomórfico para o grupo S. costalis ${ }^{+}$.

26) Expansões laterais da phallotheca: 0. presentes; 1. ausentes $(\mathrm{ic}=50, \mathrm{ir}=66)$.
A phallotheca pode apresentar na região posterior pequenas expansões laterais na forma de abas arredondadas (Figs. 51, 52, 126, 130), deprimidas lateralmente) ou não (Figs. 53 a 65, 122). Este último surge independentemente em Tibilis e no grupo $S$. beckerae ${ }^{+}$.

27) Abertura da phallotheca: 0. posterior; 1 . dorsal (ic $=100$, $\mathrm{ir}=100$ ).

A phallotheca pode apresentar a abertura voltada posteriormente (Figs. 122 e 126) ou totalmente dorsal, esta uma sinapomorfia para Similliserdia e Serdia (Figs. 53 a 65, 122).

28) Vésica: 0. em tubo cilíndrico longo; 1. em tubo cilíndrico curto ou obsoleto $(\mathrm{ic}=100, \mathrm{ir}=100)$.

Vésica em tubo cilíndrico pequeno a obsoleto, menos de $1 / 3$ até a metade do comprimento da phallotheca (Figs. 53 a 59 ) é uma sinapomorfia para o grupo $S$. beckerae ${ }^{+}$.

29) Processos da vésica: 0 . em expansões laminares; 1 . em expansões subcilíndricas $(\mathrm{i} c=100$, ir $=100)$.

Os processos da vésica podem se apresentar em expansões laminares apicais pareadas e, muitas vezes, opostas lembrando 

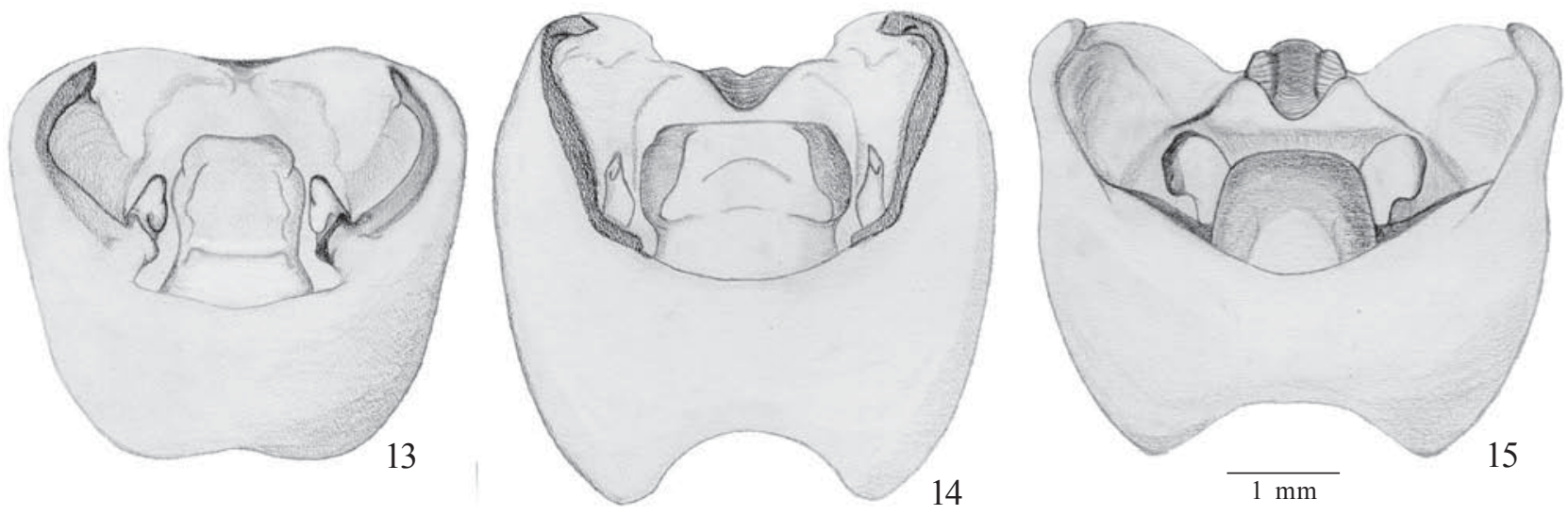

Figs. 13-15. Pigóforos, vista dorsal. 13, Serdia maxima; sp. nov.; 14, S apicicornis; 15, S. lobata.

a forma de um chapéu bávaro (Figs. 51 a 55, 60 a 65, 122, 126, 130). Expansões longas, subcilíndricas e sinuosas ou subretilíneas lembrando longos braços (Figs. 56 a 59) é uma sinapomorfia para o grupo $S$. beckerae ${ }^{+}$.

30) Abertura do ductus seminis distalis: 0. circular ou ovóide; 1 . bífido ou em calha ( $\mathrm{ic}=50, \mathrm{ir}=80$ ).

A abertura do ductus seminis distalis pode se apresentar circular ou ovóide (Figs. 51, 52, 60, 122) sendo o ductus totalmente íntegro. Dividido na extremidade, ou em calha (Figs. 53 a 59, 61 a 65) é uma sinapomorfia para o grupo $S$. beckerae ${ }^{+}$com reversão em $S$. inspersipes.

31) Bordo posterior dos laterotergitos 8: 0. sub-retilíneo dotado de um pequeno espinho; 1 . ponteagudo $(\mathrm{ic}=33$, ir $=$ 75).

Os laterotergitos 8 podem apresentar o bordo posterior sub-retilíneo projetado em um pequeno espinho mediano (Figs. $68,69,72$ a 76,132 e 133) ou apresentar o bordo posterior ponteagudo (Figs. 70, 71, 77 a 82, 131), surgindo independentemente em Tibilis, no grupo S. beckerae e no grupo S. maxima ${ }^{+}$.

32) Laterotergitos 9: 0. atingindo ou ultrapassando sutilmente a banda que une os laterotergitos $8 ; 1$. ultrapassando nitidamente esta banda $(i c=33$, ir $=75)$.

O ápice dos laterotergitos 9 pode atingir ou ultrapassar a banda que une os laterotergitos 8 em no máximo $1 / 5$ do seu comprimento (Figs. 68, 69, 72 a 76). O ápice ultrapassando nitidamente a banda em $1 / 3$ ou mais do seu comprimento (Figs. 70, 71, 77 a 82, 131) surge independentemente em Tibilis, no grupo S. beckerae ${ }^{+}$e no grupo S. maxima ${ }^{+}$.

33) Forma do ápice do laterotergitos 9: 0. arredondado; 1. truncado $(\mathrm{ic}=100, \mathrm{ir}=100)$.

O ápice dos laterotergitos 9 pode ser arredondado (Figs. 68 a 80 ) ou truncado (Figs. 81 e 82), quase retilíneo, caracterizando uma sinapomorfia para o grupo S. calligera ${ }^{+}$.
34) Comprimento máximo dos gonocoxitos 8 em relação ao comprimento dos laterotergitos 9: 0. gonocoxitos 8 com o dobro dos laterotergitos $9 ; 1$. subiguais $(\mathrm{ic}=25, \mathrm{ir}=50$ ).

Quando relacionamos o maior comprimento dos gonocoxitos 8 com o comprimento dos laterotergitos 9 medido a partir do ápice dos gonocoxitos $8 \mathrm{e}$ a forma dos laterotergitos 9 obtemos dois padrões. Os gonocoxitos 8 com cerca do dobro do comprimento dos laterotergitos 9 , estes arredondados e próximos entre si (Figs. 83, 84, 87, 90, 91, 132 e 133). E os gonocoxitos 8 com aproximadamente o mesmo comprimento dos laterotergitos 9, subcilíndricos e mais afastados entre si (Figs. 70, 71, 73, 74, 77 a 82 e 131) surgem independentemente em Tibilis e é uma sinapomorfia para o grupo $S$. beckerae ${ }^{+}$ com reversões em S. rotundicornis e o grupo S. inspersipes ${ }^{+}$.

35) Ângulos laterais externos dos gonocoxitos 8: 0. sem espinho; 1 . com espinho $(\mathrm{ic}=100$, ir $=100)$.

A presença de um pequeno espinho negro nos ângulos laterais externos dos gonocoxitos 8 (Figs. 81, 82) é uma sinapomorfia para $S$. calligera + S. maculata .

36) Posição das chitinellipsen em relação ao espessamento da íntima vaginal: 0 . laterais; 1 . posteriores $(\mathrm{ic}=100, \mathrm{ir}=100$ ).

As chitinellipsen são um par de estruturas ovaladas e esclerotizadas de tamanho variável (provavelmente aberturas de glândulas). Podem estar situadas lateralmente (Figs. 85 a $95,134,135)$ ao espessamento da íntima vaginal, ou situadas posteriormente ao espessamento se caracterizando numa sinapomorfia para S. concolor + S. indistincta (Figs. 83, 84).

37) Espessamento da íntima vaginal: 0. projetada em direção anterior; 1. projetada em direção ventral ( $\mathrm{ic}=100, \mathrm{ir}=100$ ).

$\mathrm{Na}$ grande maioria dos Pentatomini o espessamento da íntima vaginal tem origem na margem anterior da gonapófises 9 e se projeta em direção anterior (Figs. 134 e 135). O seu posicionamento sobre a metade posterior das gonapófises $9 \mathrm{e}$ projetando-se ventralmente é uma sinapomorfia para Serdia (Figs. 83 a 95). 

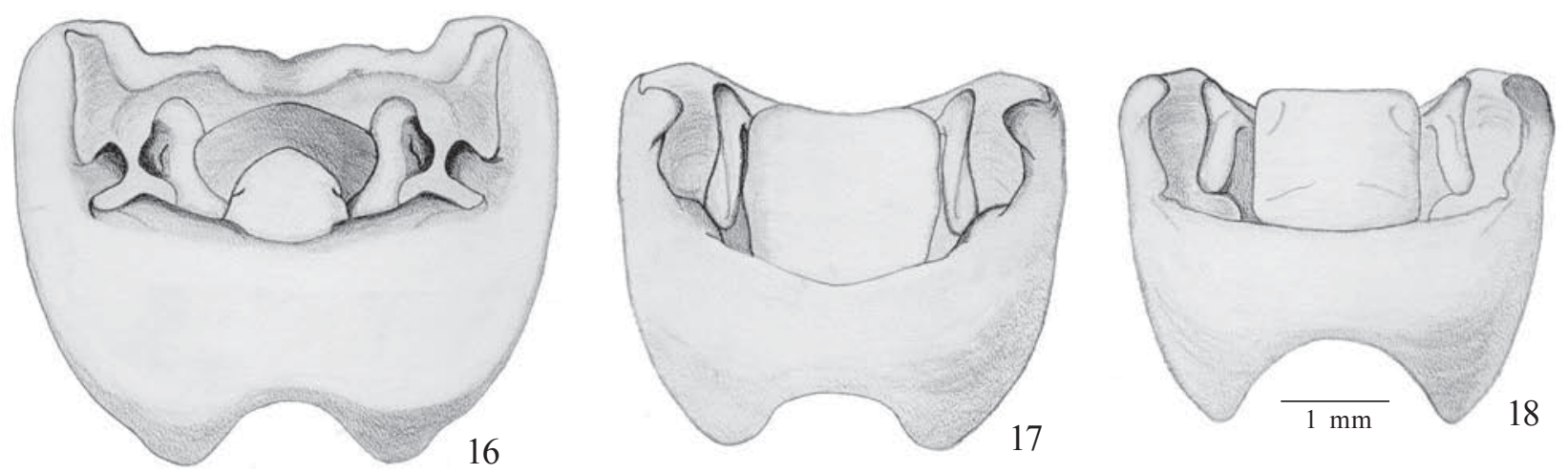

Figs. 16-18. Pigóforos, em vista dorsal. 16, Serdia costalis; 17, S. calligera; 18, S. maculata, sp. nov.

38) Espessamento da íntima vaginal: 0 . não totalmente esclerotizado; 1 . totalmente esclerotizado $(\mathrm{ic}=100, \mathrm{ir}=100)$.

O espessamento da íntima vaginal totalmente esclerotizado e escurecido em $S$. concolor $+S$. indistincta (Figs. 83 e 84) caracteriza uma sinapomorfia para o grupo.

39) Forma da pars intermedialis: 0- estreita, 1- globosa (ic $=100$, ir $=100)$.

A pars intermedialis de formato globoso, quase elíptico ou ovalado é condição sinapomórfica para o grupo $S$. rotundicornis ${ }^{+}$(Figs. 101 a 110). $50)$.

40. Capsula seminalis: 0 - globóide, 1 - ogival. (ic $=50$, ir $=$

A capsula seminalis com formato ogival (Figs. 101, 106, 107) com a extremidade apical levemente mais estreita que a base surge independentemente nos clados, S. rotundicornis e $S$. maxima + S. apicicornis.

\section{RESULTADOS DA ANÁLISE CLADÍSTICA}

$\mathrm{Na}$ análise cladística efetuada obteve-se um único cladograma (Fig. 139) com 83 passos, índice de consistência de 0,51 e índice de retenção de 0,75. Ao analisarmos o cladograma verificamos que:

O gênero Similliserdia é grupo-irmão de Serdia pelo compartilhamento de cinco sinapomorfias: comprimento do $2^{\circ}$ artículo antenal com $1 / 3$ ou menos do comprimento do $3^{\circ}$ artículo $\left(3_{1}\right), 1^{\circ}$ artículo do rostro contido totalmente dentro das búculas $\left(6_{1}\right)$, peritrema ostiolar de forma auricular $\left(12_{1}\right)$, folheto externo do bordo ventral do pigóforo, medianamente, com $1+1$ projeções $\left(23_{2}\right)$ e abertura da phallotheca dirigida dorsalmente (27, ).

A monofilia de Serdia é sustentada por três sinapomorfias: coloração apical do escutelo enegrecida (11 $)$, parede da taça genital com processo em aba $\left(20_{1}\right)$ e espessamento da íntima vaginal projetada ventralmente $\left(35_{1}\right)$.

A linhagem constituída pelos clados $S$. beckerae ${ }^{+}$e $S$. bihamulata $^{+}$tem sua monofilia sustentada por 2 sinapomorfias: vésica em tubo cilíndrico pequeno a obsoleto $\left(28_{1}\right)$, e abertura do ductus seminis distalis de forma bífida ou em calha ( $\left.30_{1}\right)$. Três homoplasias, que ocorrem independentemente em Tibilis, corroboram a monofila do grupo: terço apical das jugas justapostas diante do clípeo $\left(2_{1}\right)$, ausência de expansões laterais da phallotheca $\left(26_{1}\right)$ e gonocoxitos 8 de comprimento subigual aos laterotergitos $9\left(34_{1}\right)$.

O grupo $S$. maxima ${ }^{+}$tem sua monofilia sustentada por três homoplasias: ângulos umerais desenvolvidos $\left(8_{1}\right)$, margem posterior dos laterotergitos 8 projetada de forma triangular $\left(31_{1}\right)$ e laterotergitos 9 ultrapassando nitidamente a banda que une dorsalmente os laterotergitos $8\left(30_{1}\right)$.

O resultado sugere a existência de, pelo menos, três grupos de espécies: $S$. concolor $+S$. indistincta, $S$. beckerae ${ }^{+}$e $S$. bihamulata $^{+}$; neste último, pode-se sugerir ainda a existência de dois ou três grupos intimamente relacionados como $S$. inspersipes $+S$. robusta, $S$. maxima $+S$. apicicornis e $S$. lobata $^{+}$.

A proximidade de Serdia com Tibilis (sustentada por 6 homoplasias) e Neotibilis (sustentada por uma homoplasia) apoiam as propostas citadas na literatura (Stål 1867; Becker 1967 e Grazia \& Barcellos 1994). Porém uma análise posterior incluindo todas as espécies dos grupos externos poderá corroborar a hipótese de parentesco entre estes gêneros.

\section{Serdia Stål, 1860}

(Fig. 1)

Serdia Stål, 1860: 25 (descrição); Stål, 1867: 531 (chave); Stål, 1872: 45 (redescrição, catálogo); Lethierry \& Severin, 1893: 179 (catálogo).

Serdia (Serdia); Kirkaldy, 1909: 140 (catálogo); Becker, 1967: 85 (revisão, chave); Rolston et. al., 1980: 22 (chave); Froeschner, 1981: 532 (diagnose); Thomas \& Rolston, 1985: 1165-1172 (redescrição, chave).

Serdia (Brasiliicola) Kirkaldy, 1909: 140-141 (catálogo); Becker, 1967: 85-89, 101-103 (revisão, chave); Thomas \& Rolston, 1985: 1165 (chave). Syn. nov.

Espécie-tipo: Serdia apicicornis Stål, 1860, designação subseqüente por Kirkaldy, 1909.

Diagnose. Espécies com 9,3 a 17,5 mm de comprimento. Jugas mais longas que o clípeo; $2^{\circ}$ artículo antenal muito 
reduzido, no máximo $1 / 3$ do comprimento do $3^{\circ}$ artículo, podendo ser menor ou igual ao $1^{\circ}$; rostro curto, não atingindo a base do abdome; ângulos umerais projetados anteriormente ou não; ápice do escutelo, em geral, com a margem delicadamente delineada de negro nas laterais; mesosterno e metasterno elevados, o último emarginado posteriormente para receber o espinho mediano do $3^{\circ}$ segmento abdominal; tíbias largamente sulcadas.

Forma do corpo ovalada a arredondada, moderadamente convexo tanto dorsal quanto ventralmente, maior largura podendo ser ao nível do abdome ou na altura dos ângulos umerais quando estes forem desenvolvidos. Superfície coberta por pontuações castanho-escuras de tamanho variável para cada espécie.

Cabeça mais larga ao nível dos olhos que longa medianamente na maioria das espécies, margem anteocular fortemente sinuosa, convergindo para um ápice arredondado, estreito ou alargado; jugas mais longas que o clípeo, terço apical levemente sobreposto ou justaposto no ápice formando um "V" aberto. Olhos castanho-avermelhados, ocelos vermelhos e duas vezes mais distantes entre si do que a distância de cada ocelo para o olho mais próximo. Pontuações castanho-escuras, irregularmente distribuídas, muito ou moderadamente densas, particularmente sobre as jugas, menos densas sobre o clípeo e aglutinadas junto ao bordo posterior dos ocelos. Tubérculo antenífero visível em vista dorsal, com um pequeno espinho de ponta romba no ângulo lateral externo. Primeiro artículo antenal atingindo ou ultrapassando o ápice da cabeça, $2^{\circ}$ menor do que o $3^{\circ}$, correspondendo a $1 / 6$ até $1 /$ 3 do comprimento do $3^{\circ}$, este com ou sem sulco longitudinal por quase todo o artículo, $3^{\circ}, 4^{\circ}$ e o $5^{\circ}$ de comprimento aproximadamente igual. Todos os artículos da mesma espessura, exceto o $4^{\circ}$ que pode ser dilatado com um achatamento dorso-ventral em algumas espécies. Quinto segmento totalmente âmbar na maioria das espécies e destituído de pontuações ou pelo menos os $4 / 5$ apicais do mesmo. Búculas anteriormente elevadas, arredondadas e próximas entre si, seguindo paralelas, decrescendo em altura e evanescentes posteriormente, raramente atingindo a base da cabeça; porção anterior projetada em ângulo reto. Superfície das búculas pontuada. Primeiro artículo do rostro pouco mais curto ou do comprimento das búculas; $2^{\circ}$ artículo pouco menor do que o $3^{\circ} \mathrm{e} o 4^{\circ}$ reunidos, ápice do rostro não atingindo a base do abdome. Pronoto de forma variada, em linhas gerais trapezoidal, pelo menos duas vezes mais largo através dos úmeros do que longo medianamente. Margem anterior do pronoto tão larga quanto a cabeça, moderadamente sinuosa para encaixe desta, truncada atrás dos olhos. Dentículo dos ângulos ântero-laterais pequeno, pontiagudo e lateralmente dirigido. Margens ântero-laterais arredondadas ou subretilíneas, superfície lisas ou crenuladas e, em geral, estreitamente emarginadas. Ângulos umerais desenvolvidos ou não. Margens póstero-laterais e posterior sub-retilíneas. Superfície do pronoto com pontuações castanho-escuras de tamanho variável, densas ou moderadamente densas, com distribuição variável entre as espécies. Cicatrizes, em geral, concolores a castanho-escuras delimitadas por pequenas pontuações castanhas. Escutelo triangular, em geral, levemente mais longo que largo na base, cada ângulo basal com uma pequena fóvea negra, esta acompanhada ou não por um calo alaranjado. Região pós-frenal ora com margens subparalelas, ora estreitando-se gradativamente em direção ao ápice, este levemente delineado de negro e de coloração variada entre as espécies. Hemiélitro com o cório mais longo que o escutelo, ângulos apicais agudos, sutura da membrana sub-retilínea. Superfície com pontuações uniformemente densas e com distribuição variável para as espécies, célula discal pálida, conspícua ou não. Membrana hialina, fracamente escurecida, cinco a oito nervuras longitudinais, ocasionalmente bifurcadas. Superfície torácica ventral em geral castanho-clara a amarelada, pontuações castanhas de distribuição e densidade variável para cada espécie. Prosterno triangular, rasamente sulcado, carena mesosternal elevada, comprimida e pondendo projetar-se sobre o prosterno (este caráter é variável intraespecificamente); posteriormente a carena mesosternal pode ser afilada ou truncada (de acordo com a forma do metasterno). Áreas evaporatórias mesopleurais percorrendo uma faixa irregular que ocupa um pouco mais que $1 / 3$ basal da mesopleura ampliando-se em direção às margens laterais. Metasterno elevado, plano, da mesma altura do mesosterno, hexagonal quando sua margem anterior se apresenta bem desenvolvida e pentagonal em caso contrário. Área evaporatória metapleural pontuada, atingindo a margem lateral do esclerito, truncada e formando uma prega longitudinal que delimita o terço externo da metapleura. Peritrema ostiolar curto, auricular. Segmentos do conexivo estreitos, quase totalmente encobertos ou largamente expostos, imaculados ou com manchas escuras, quase negras nos ângulos laterais anteriores e posteriores; superfície densamente pontuada, pontuações castanho-claras a concolores, ângulos póstero-laterais apicais não salientes ou salientes e pontiagudos, enegrecidos ou não. Supefície ventral do abdome densa a moderadamente pontuada, pontuações castanho-claras a castanho-escuras, menores e mais densas numa faixa longitudinal larga acompanhando os espiráculos, pontuações maiores e mais esparsas no restante. Área discal do abdome pode estar delimitada ou não por uma série contínua de máculas calosas lisas e lúteas formando dois semicírculos por urosternito, voltados para os espiráculos. Espiráculos negros com um ponto amarelado caloso na sua margem interna. Espinho mediano do $3^{\circ}$ segmento abdominal agudo ou reto a obtuso. Pernas castanho-claras a amareladas com ou sem pontuações grosseiras, ferrugíneas, tíbias sulcadas dorsalmente, tarsos,em geral, avermelhados.

Genitália do macho. Pigóforo quadrangular ou subquadrangular, ângulos póstero-laterais algumas vezes com tufos de pêlos. Parede da taça genital espessada freqüentemente formando processos em abas escurecidas. Bordo dorsal com ou sem processo. Bordo ventral medianamente escavado, projetado ou não em direção dorsal; folheto superior e, as vezes, o folheto inferior com projeções 

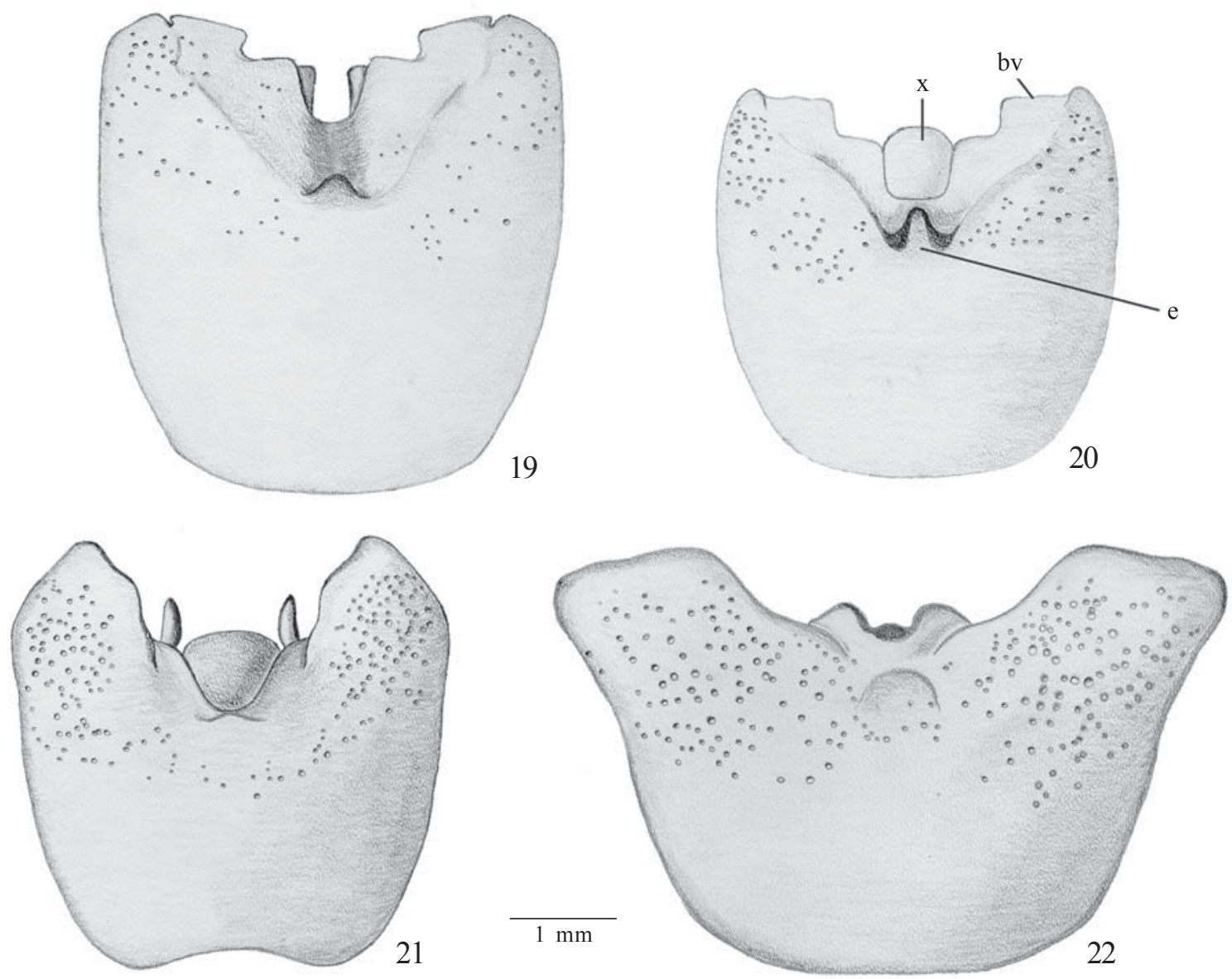

Figs. 19-22. Pigóforos, em vista ventral. 19, Serdia concolor (10 segmento omitido); 20, S. indistincta, sp. nov.; 21, S. inspersipes; 22, S. robusta, sp. nov.; bv=bordo ventral, $\mathrm{e}=$ espinho, $\mathrm{X}=$ décimo segmento.

únicas ou em pares. Décimo segmento posicionado perpendicularmente ou paralelamente ao plano sagital, com o ânus abrindo-se ventralmente. Parâmeros com forma e tamanho bastante variáveis entre as espécies, posicionados perpendicular ou paralelamente ao plano sagital. Phallus. Aparelho articular reduzido em relação a phallotheca, composto por uma placa basal estreita, conectivos dorsais curtos e processus capitati pequenos e cônicos. Phallotheca fortemente recurvada com abertura posterior posicionada dorsalmente, com ou sem expansões nos ângulos pósterolaterais. Conjuntiva ausente. Vésica em tubo cilíndrico de tamanho variável que abraça dorsalmente o ductus seminis distalis e dotado de processos apicais de tamanho e forma variáveis nas espécies; gonoporo secundário também variável na forma.

Genitália da fêmea. Superfície das placas genitais pontuadas ou não, de tamanho variado, $7^{\circ}$ esternito com margem posterior côncava ou subangulada e ovalada sobre os gonocoxitos 8 . Laterotergitos 8 subiguais ou quase o dobro do comprimento dos laterotergitos 9 , margem posterior portando ou não um pequeno espinho. Laterotergitos 9 com ápice arredondado ou truncado. Décimo segmento quadrangular. Gonocoxitos $9 \mathrm{com}$ margem anterior lateralmente projetada em longos braços, margem posterior convexa e recobrindo parcial ou totalmente o décimo segmento. Gonapófises 9 com espessamento da íntima vaginal situado na sua metade posterior projetando-se ventralmente, totalmente esclerotizado em $S$. concolor e $S$. indistincta ou formando anéis incompletos. Chitinellipsen situadas de cada lado ou posteriormente ao espessamento da íntima vaginal. Ductus receptaculi variando seu comprimento comparativamente entre a região anterior à área vesicular e a região posterior a mesma área. Diâmetro do tubo interno variando de calibre sendo mais amplo na região proximal e afilando-se progressivamente em direção distal. Pars intermedialis estreita ou globosa, e em geral, com uma pequena área menos esclerotizada no seu terço apical. Capsula seminalis globóide ou ogival e com número e tamanho de dentes variáveis nas espécies.

Comentários. Becker (1967) ao revisar o gênero diferenciouo de Tibilis pela estrutura do peritrema ostiolar (em Serdia é curto, ápice digitiforme terminando abruptamente pouco além do ostíolo odorífero, em Tibilis é em forma de uma prega alongada acompanhando a margem anterior do esclerito e 

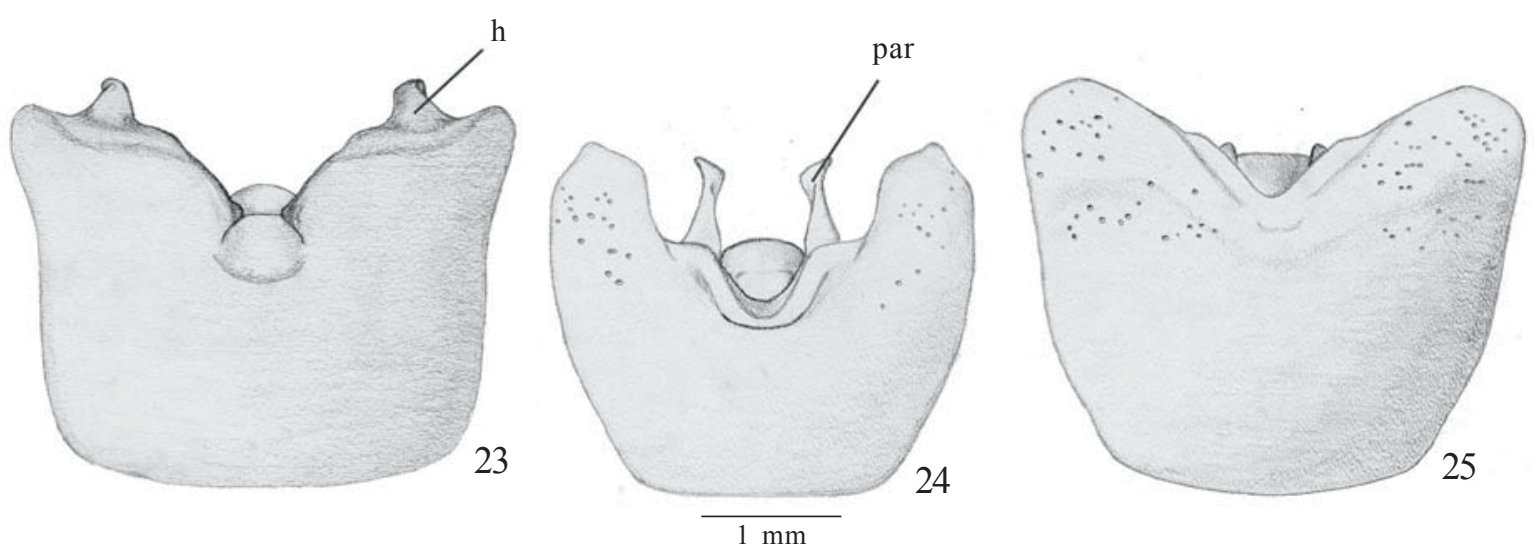

Figs. 23-25. Pigóforo, vista ventral. 23, Serdia bihamulata; 24, S. rotundicornis; 25, S. limbatipennis; h=hâmulus, par=parâmeros.

progressivamente estreitada em direção à margem lateral da metapleura), pelas relações do comprimento entre os três primeiros artículos antenais (em Serdia o $1^{\circ}$ atingindo o ápice da cabeça, $2^{\circ}$ artículo curtíssimo, correspondendo de $1 / 6$ a $1 / 3$ do comprimento do $3^{\circ}$; em Tibilis o $1^{\circ}$ artículo superando o ápice da cabeça, $2^{\circ}$ e $3^{\circ}$ aproximadamente iguais) e a forma das búculas (em Serdia são anteriormente elevadas, arredondadas e próximas entre si, seguindo paralelas, decrescendo em altura e evanescentes posteriormente; em Tibilis são elevadas, triangulares e unidas posteriormente). Froeschner (1981) ao descrever Elsiella, para incluir a espécie Ebora plana Walker (1867), comparou-o a Serdia pela estrutura do pro, meso e metasterno, este último com encaixe para o tubérculo abdominal. Comentou, neste artigo, que de acordo com Rolston et al. (1980) a espécie Ebora plana deveria ser um membro do gênero Serdia, pois além das características mencionadas acima, tem as jugas unidas diante do clípeo. Porém o autor separa-os principalmente pelo comprimento do segundo artículo antenal (que em Serdia corresponde a menos da metade do comprimento do terceiro e em Elsiella mede $4 / 5$ do comprimento do terceiro), área evaporatória (não rugosa em Serdia e fortemente rugosa em Elsiella) e pela coloração geral do corpo (amarelo sujo com inúmeras pontuações negras em Serdia e castanho-avermelhado brilhante com pontuações concolores em Elsiella). O exame do holótipo de E. plana depositado no Natural History Museum (Londres) somado a descrição apresentada pelo autor, permitem afirmar que se trata de outro gênero. Levando em consideração a morfologia da genitália de ambos os sexos que neste estudo evidenciam duas sinapomorfias para Serdia, nos machos a parede da taça genital formando processos em abas, e nas fêmeas, o espessamento da íntima vaginal posicionado sobre a metade posterior da gonapófise 9 , separam este gênero de qualquer outro descrito para Pentatomini.

Distribuição. Costa Rica, Panamá, Colômbia, Venezuela, Equador, Peru, Brasil, Bolívia, Paraguai e Argentina (Figs. 136, 137 e 138).
Chave para as espécies de Serdia [Modificada de Becker (1967) e Rolston \& Thomas (1985)]

1. Área discal do abdome delimitada por uma série de máculas calosas, sendo duas por segmento (Fig. 115) 2

Área discal do abdome não delimitada por máculas calosas 4

2(1). Pronoto, escutelo e hemiélitros com manchas amareloescuras dorsais em forma de bandas submarginais laterais e subtriangulares no disco do pronoto, discoidal ramboidal mediana no escutelo e em banda subcostal no hemiélitro ....... S. costalis Ruckes, 1958

Pronoto, escutelo e hemiélitros sem manchas ............. 3

3(2). Bordo dorsal do pigóforo com processos pares laterais do terço mediano inconspícuos (Fig. 18); fêmeas com margem posterior dos gonocoxitos 8 trissinuoso (Fig. 82) S. maculata sp.nov.

Bordo dorsal do pigóforo com processos pares laterais do terço mediano em forma de abas largas, deprimidas dorso-ventralmente, ápices voltados para os parâmeros (Fig. 17); fêmeas com margem posterior dos gonocoxitos 8 convexa (Fig. 81) .......... S. calligera Stål, 1860.

4(1). Ângulos umerais desenvolvidos em projeções dirigidas ântero-lateralmente, ápice arredondado, comprimento maior que a distância entre os olhos (Fig. 108) 5

Ângulos umerais não desenvolvidos, se pronunciados de comprimento menor que a distância entre os olhos (Figs. 109 e 110) . ...8

5(4). Conexivo com manchas escuras nos ângulos laterais anteriores e posteriores de cada segmento (Fig. 108)

Conexivo imaculado (Fig. 109) ... 7 

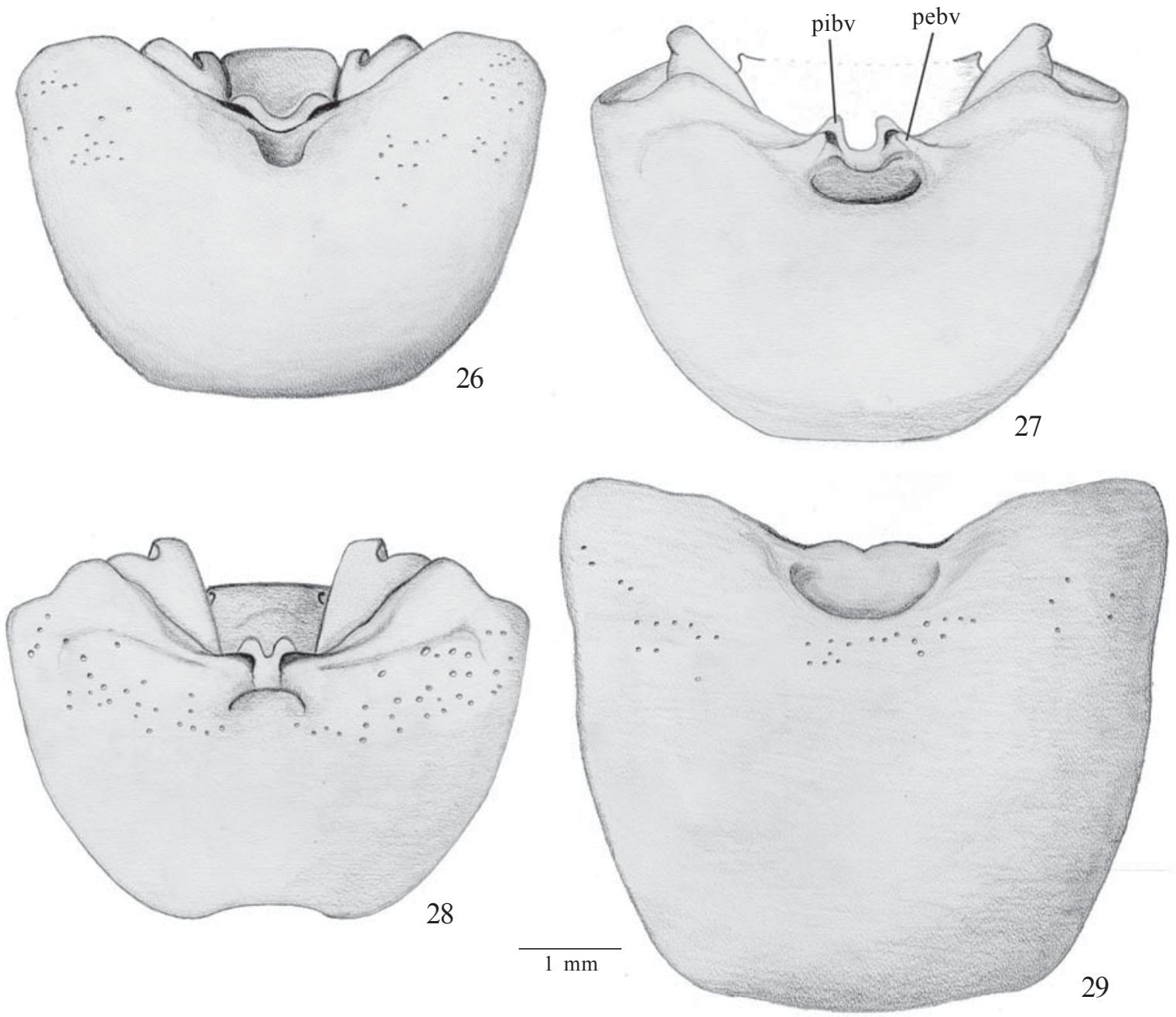

Figs. 26-29. Pigóforo, vista ventral. 26, Serdia beckerae; 27, S. quadridens (10 segmento omitido); 28, S. delphis; 29, S. ruckesi; pebv=processo externo do bordo ventral, pibv=processo interno do bordo ventral.

6(5). Machos com o bordo dorsal do pigóforo medianamente côncavo, processos laterais laminares, enegrecidos apicalmente (Fig. 13), parâmeros subcilíndricos com 2 projeções convergentes (Fig. 46); fêmeas com margem posterior dos gonocoxitos 8 rasamente côncava (Fig. 77) S. maxima sp. nov.

Machos com bordo dorsal do pigóforo com 1+1 abas negras laterais ao $10^{\circ}$ segmento, parâmeros subquadrangulares com 2 projeções orientadas para o mesmo lado (Fig. 14); fêmeas com margem posterior dos gonocoxitos 8 suavemente arredondada, e enegrecida junto aos bordos suturais (Fig. 78) S. apicicornis Stål, 1860

7(5). Superfície dorsal do $3^{\circ}$ segmento antenal com sulco longitudinal (Fig. 98)

S. lobata Thomas \& Rolston, 1985

Superfície dorsal do $3^{\circ}$ segmento antenal destituído de sulco longitudinal .. S. rotundicornis Becker, 1967
8(4). Hemiélitros, nas fêmeas, com o cório atingindo a margem posterior do $5^{\circ}$ segmento abdominal (Fig. 110); machos com bordo dorsal do pigóforo fortemente sinuoso, terço mediano com dois pares de processos, um laminar com ápice enegrecido e voltado para os parâmeros e outro digitiforme de cada lado do $10^{\circ}$ segmento (Fig. 8)

S. limbatipennis Stål, 1860

Hemiélitro, nas fêmeas, com o cório atingindo a margem posterior do $6^{\circ}$ segmento abdominal; machos com bordo dorsal do pigóforo não como acima 9

9(8). Margens ântero-laterais do pronoto, margens laterais do conexivo (dorsalmente) e margens do abdome (ventralmente) com uma linha vermelha submarginal S. inspersipes Stål, 1860

Margens ântero-laterais do pronoto, do conexivo e margens do abdome sem esta linha 10 

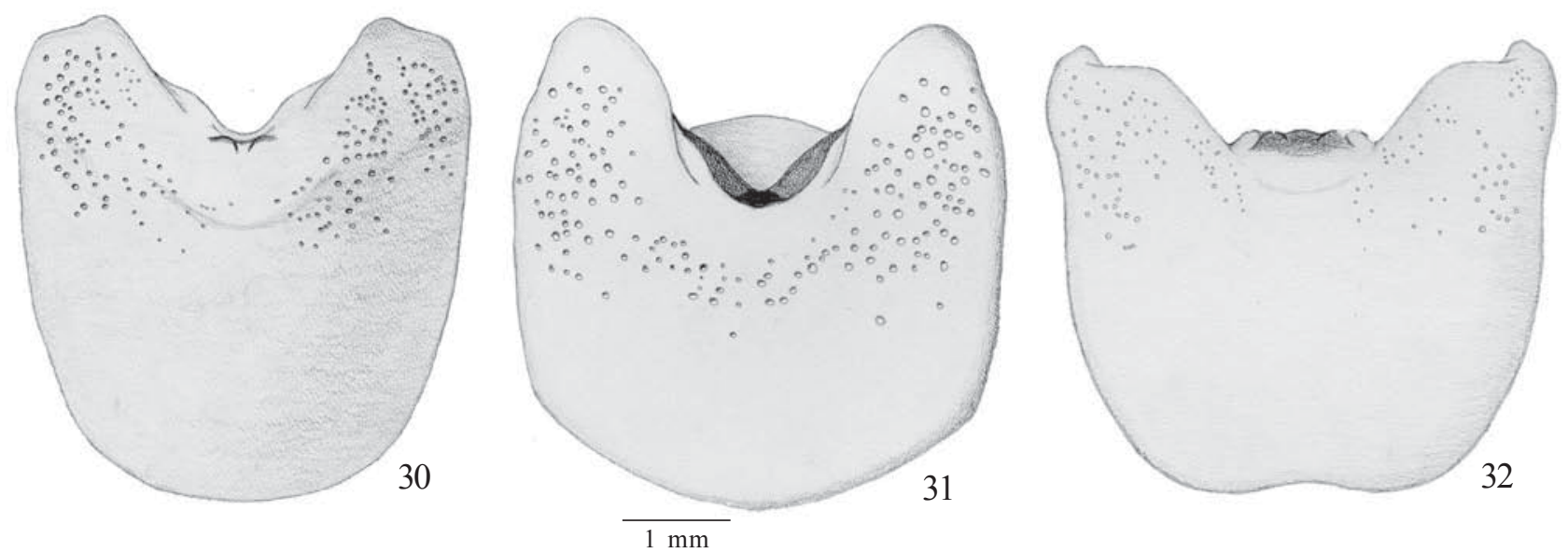

Figs. 30-32. Pigóforo, vista ventral. 30, Serdia maxima; sp. nov.; 31, S. apicicornis; 32, S. lobata.

10(9). Pronoto com 1+1 faixas longitudinais de pontuações equidistantes do eixo longitudinal mediano que iniciam na margem posterior das cicatrizes e terminam na margem posterior do pronoto

S. bicolor sp. nov.

Pronoto sem estas faixas longitudinais de pontuações

11

11(10). Machos com tufos de pêlos nos ângulos pósterolaterais do pigóforo (Fig. 118), parâmeros delgados com uma projeção extremamente longa e curva (Figs. 42 a 45); fêmeas com os laterotergitos 9 ultrapassando nitidamente a banda que une dorsalmente os laterotergitos 8 (Figs. 70 e 71) ..... 12

Machos e fêmeas não como acima .. 15

12(11). Ápice do escutelo totalmente de cor clara ou concolor

Ápice do escutelo com bordos laterais delineados de negro (Figs. 108 a 109) 14

13(12). Parâmeros com duas projeções, uma lateral lobada e uma apical extremamente longa e curva (Fig. 44); fêmeas com os gonocoxitos 9 com margem posterior fortemente convexa e projetando-se sobre o $10^{\circ}$, encobrindo-o quase totalmente (Fig. 71)

S. delphis Thomas \& Rolston, 1985

Parâmeros com uma projeção extremamente longa e curva (Fig. 45); fêmea desconhecida

S. ruckesi Thomas \& Rolston, 1985

14(12). Corpo em forma arredondada, bordo ventral do pigóforo, medianamente, com $1+1$ projeções laminares pequenas e escurecidas no folheto superior (Fig. 26), fêmeas com gonocoxitos totalmente amarelados
Corpo em forma ovalada, bordo ventral do pigóforo, medianamente, com $1+1$ projeções digitiformes no folheto superior (Fig. 27); fêmea desconhecida .... S. quadridens Thomas \& Rolston, 1985

15(11). Quarto artículo antenal dilatado, bordo ventral do pigóforo fortemente projetado dorsalmente com 1+1 projeções digitiformes voltadas para os ângulos póstero-laterais (Fig. 23)

S. bihamulata Thomas \& Rolston, 1985

Quarto artículo antenal cilíndrico, bordo ventral do pigóforo não projetado dorsalmente ou se projetado não como acima

16(15). Pigóforo em formato de sino com taça genital amplamente aberta (Fig. 5); fềmeas com gonocoxitos 8 sub-retangulares (Fig. 76), chitinellipsen situadas lateralmente ao espessamento da íntima vaginal (Fig. 90) S. robusta sp. nov.

Pigóforo de contorno quadrangular, taça genital ventralmente com uma projeção mediana (Fig. 2), fêmeas com os gonocoxitos 8 subtriangulares (Fig. 68), chitinellipsen situadas posteriormente ao espessamento da íntima vaginal (Fig. 83) ........... 17

17(16). Pigóforo com espinho triangular mediano bem desenvolvido na taça genital, em vista ventral (Fig. 20), fêmeas com espessamento da íntima vaginal truncado na base (Fig. 84)

S. indistincta sp. nov.

Pigóforo com um pequeno dente mediano na taça genital, em vista ventral (Fig. 19), fêmeas com espessamento da íntima vaginal estreitado na base (Fig. 83) S. concolor Ruckes, 1958 

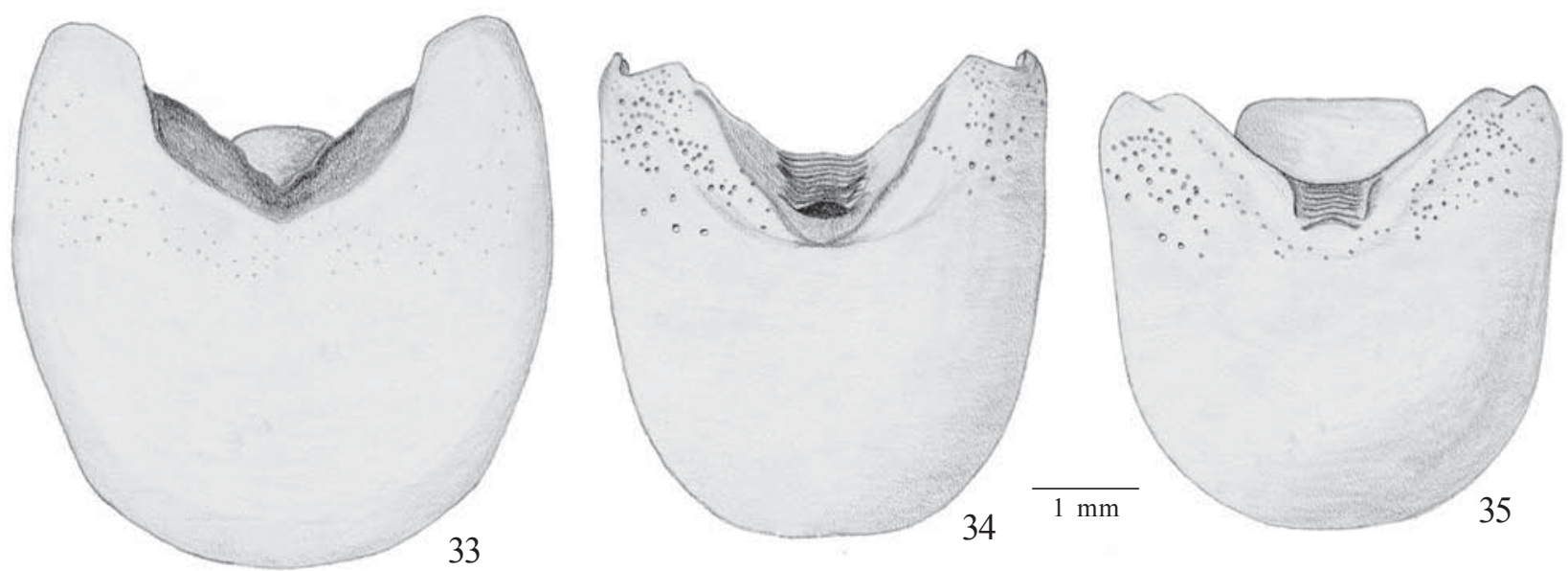

Figs. 33-35. Pigóforo, vista ventral. 33, Serdia costalis; 34, S. calligera; 35, S. maculata, sp. nov.

Serdia concolor Ruckes, 1958

(Figs. 2, 19, 36, 51, 68, 83, 96, 104, 111)

Serdia concolor Ruckes, 1958b: 12 (descrição).

Serdia (Serdia) concolor; Becker, 1967: 98 (revisão, chave); Becker \& Grazia-Vieira, 1971: 20 (catálogo); Link \& Grazia, 1983: 124 (registro de ocorrência); Grazia, 1984: 80 (registro de ocorrência); Thomas \& Rolston, 1985: 1165 (chave); Link \& Grazia, 1987: 121 (registro de ocorrência).

Macho. Medidas ( $\mathrm{n}=29)$ : comprimento total 14,1 $(15,8-12,1)$ 0,6 ; largura abdominal 7,5 (8,2-6,2) 0,3 ; comprimento da cabeça $2,2(2,5-2,0) 0,1$; largura da cabeça $2,8(3,2-2,5) 0,1$; comprimento dos artículos antenais I $0,9(1,6-0,8) 0,2$; II $0,7(0,8-0,6) 0,1$; III $1,9(2,4-1,0) 0,4$; IV 2,4 (3,0-2,1) 0,6 ; V 2,1 $(2,7-1,7) 0,4$; comprimento do pronoto $3,3(4,0-2,9) 0,2$; largura anterior do pronoto $3,1(3,4-2,7) 0,1$; largura posterior do pronoto $7,4(8,4-$ $6,4) 0,3$; comprimento do escutelo $5,7(6,2-4,7) 0,2$; largura do escutelo 4,6 (5,4-3,9) 0,2.

Descrição. Forma arredondada, coloração castanhoavermelhada, com pontuações ferrugíneas brilhantes, predominantemente uniformes no tamanho, densas e igualmente distribuídas. Cabeça com margem anteocular fortemente sinuosa, convergindo para um ápice arredondado e estreito; jugas contíguas apicalmente (Fig. 96); disco da cabeça fracamente escavado e provido com numerosas rugas finas, oblíquas. Primeiro segmento antenal atingindo ou excedendo o ápice da cabeça, de coloração castanhoavermelhada, bem como o $2^{\circ}$ artículo; $3^{\circ}$ enegrecido, $4^{\circ}$ com terço basal amarelo-escuro, porção apical negra e $5^{\circ}$ artículo inteiramente amarelo-escuro. Rostro não atingindo o limite anterior da placa metasternal (Fig. 104). Pronoto com ângulos umerais não desenvolvidos, margens ântero-laterais subparalelas, fraca e estreitamente emarginadas; pontuações uniformes, densas e igualmente distribuídas, cicatrizes concolores. Margem apical do escutelo não emarginada e delicadamente delineada de negro nas laterais. Hemélitro com superfície densamente pontuada, pontuações atingindo a margem costal, exceto anteriormente. Célula discal pálida e envolvida por uma pequena mancha escura. Superfície torácica ventral de coloração amarelo-escura, com pontuações ferrugíneas, grosseiras e mais espalhadas que no dorso. Segmentos do conexivo, em geral, recobertos pelo cório, superfície densamente pontuada, pontuações concolores, ângulos póstero-laterais pequenos, negros e fortemente apiculados. Superfície ventral do abdome com o espinho mediano do $3^{\circ}$ segmento abdominal obtuso. Pernas de coloração ocre, pontuações de cor ferrugem, conspícuas e grosseiras nos fêmures, menos densas nas tíbias, tarsos avermelhados.

Genitália. Pigóforo de contorno quadrangular; ângulos póstero-laterais com um profundo entalhe mediano, bordo dorsal arredondado, destituído de processos (Fig. 2); bordo ventral projetando-se dorsalmente, trissinuoso, medianamente recortado em "U". Parede ventral do pigóforo com uma ranhura pré-apical em "V" aberto, medianamente com uma pequena elevação, coincidente com a escavação mediana do bordo ventral (Fig. 19). Décimo segmento perpendicular ao plano sagital, de formato arredondado, estreitando-se apicalmente e terminando numa fileira de pêlos (Fig. 2). Parâmeros posicionados perpendicularmente ao plano sagital, subquadrangulares com duas projeções voltadas para o bordo dorsal de tamanho diferenciado, sendo a basal mais curta e com longos pêlos na margem apical; a apical levemente mais longa, mais estreita apicalmente, destituída de pêlos. Ambas projeções estão associadas entre si lembrando uma pinça (Fig. 36). Phallus. Phallotheca com $1+1$ expansões laterais em forma de abas largas. Vésica em tubo cilíndrico longo, com pelo menos 2/3 do comprimento da phallotheca, pronunciado apicalmente num par de expansões laminares de superfície interna irregular (Fig. 51). Ductus seminis distalis extremamente curto surgindo na altura mediana do tubo cilíndrico. Gonoporo secundário arredondado.

Fêmea semelhante ao macho. Medidas $(\mathrm{n}=15)$. Comprimento total $15,5(16,8-13,8) 0,5$; largura abdominal 8,1 $(8,6-7,1) 0,2$; comprimento da cabeça $2,3(2,5-2,2) 0,1$; largura da cabeça $2,9(3,2-2,7) 0,1$; comprimento dos artículos antenais 


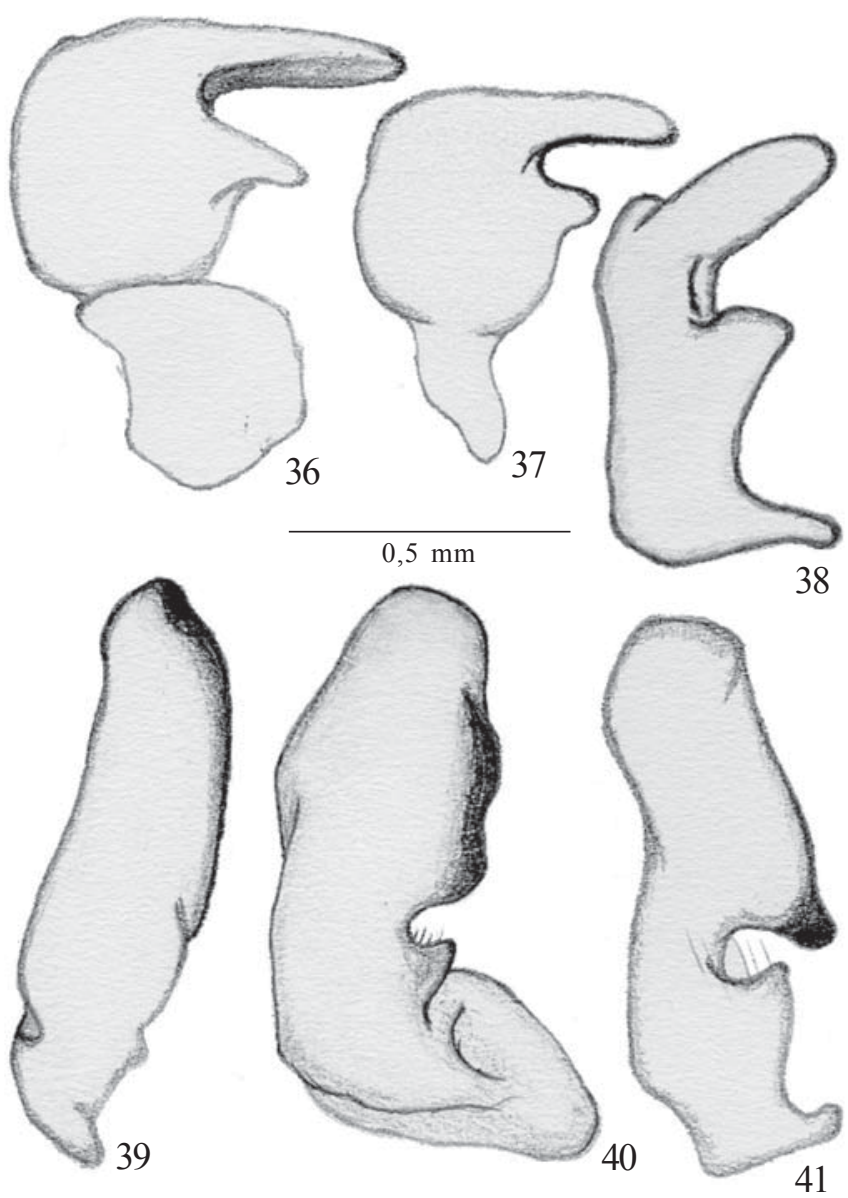

Figs. 36-41. Parâmero esquerdo, vista lateral externa. 36, Serdia concolor; 37, S. indistincta, sp. nov.; 38, S. bihamulata; 39, S. rotundicornis; 40, S. limbatipennis; 41, S. inspersipes.

I $0,9(1,1-0,7) 0,1$; II $0,7(0,8-0,7) 0,1$; III $1,9(2,1-1,6) 0,2$; IV 2,3 $(2,6-2,0) 0,3$; V 2,3 $(2,4-2,1) 0,1$; comprimento do pronoto 3,6 $(3,9-3,2) 0,1$; largura anterior do pronoto $3,2(3,7-2,9) 0,1$; largura posterior do pronoto $7,9(8,2-6,9) 0,2$; comprimento do escutelo $6,1(6,6-5,4) 0,2$; largura do escutelo $4,9(5,4-4,2) 0,2$.

Genitália. Superfície das placas genitais densa e uniformemente pontuada. Sétimo esternito com margem posterior côncava sobre os gonocoxitos 8 . Laterotergitos 8 arredondados, subiguais em comprimento aos laterotergitos 9, bordo posterior sub-retilíneo com um pequeno espinho mediano. Laterotergitos 9 com ápice arredondado e não ultrapassando a banda que une dorsalmente os laterotergitos 8. Gonocoxitos 8 subtriangulares, com cerca do dobro do comprimento dos laterotergitos 9 , margem posterior convexa bordos suturais paralelos em quase toda a sua extensão, divergindo no terço posterior em forma de "V" (Fig. 68). Gonocoxitos 9 com margem anterior projetada em longos braços laterais sobre a gonapófise 9, margem posterior avançando sobre a base do $10^{\circ}$ segmento. Gonapófises $9 \mathrm{com}$ espessamento da íntima vaginal totalmente esclerotizado em tubo cilíndrico levemente estreitada na extremidade, situado medianamente na gonapófise 9 e projetado ventroanteriormente. Chitinellipsen situadas posteriormente ao espessamento da íntima vaginal. Comprimento do ductus receptaculi, na região anterior a área vesicular, com 1,5 vezes o comprimento do ductus.culi na região posterior. Ductus receptaculi posterior a área vesicular relativamente longo, diferenciando-se das outras espécies, exceto $S$. indistincta sp. nov. Cristas anulares anterior e posterior convergentes, pars intermedialis fortemente estreita. Capsula seminalis com dentes em número variável dentro da espécie, recurvos surgindo da porção basal e levemente ultrapassando a crista anular anterior em 1/3 do seu comprimento (Fig. 83).

Distribuição: Venezuela: Distrito Federal; Brasil: Minas Gerais, Rio de Janeiro, São Paulo, Paraná, Santa Catarina, Rio Grande do Sul; Bolívia: Chapare; Paraguai: Ciudad de Leste; Argentina: Misiones.

Material examinado. Holótipo macho, com as etiquetas: a) Corupá (Hansa Humbolt) S[anta]. Cath[arina], Brazil; Dec. 1944; b) A. Maller, coll. Frank Johnson doador; c) Serdia concolor Ruckes, Holotype. (AMNH). Parátipo. BRASIL. Santa Catarina: Rio Vermelho, fêmea, XII-1944, A. Maller, coll. Frank Johnson Donor (AMNH). BRASIL. Minas Gerais: Serra do Caraça, macho, III-1963, F. Werner, U. Martins, L. Silva (MZSP); Fazenda dos Campos, S. de Minas Gerais, macho, s/ data, s/ coletor (ZMHB); Rio de Janeiro: Itatiaia, $800 \mathrm{~ms}$., macho, XII-1933, S. Lopes, E.T.R.Cunha (MNRJ); Itatiaia, 800ms., macho, 01-XII-1947, col. J.F.Zikan n ${ }^{\circ}$ 2733, J. F.Zikan (FIOC); Itatiaia, 800ms, macho, XII-1950, L. Travassos (MNRJ); Cachoeira de Macacu, 800m, fêmea, 15-X-1985, Scott E. Miller (NMNH); Petrópolis, 600m, fêmea, 10-X-1985, Scott E. Miller (NMNH); Corcovado, fêmea, 1954, Zajciv leg. (MNRJ); Corcovado, fêmea, 5-XI-1966, Carlos Roberto leg., (MNRJ); Seropédica, Est. Rio-São Paulo Km 47, fêmea, 04-II-1943, O. Braga leg., (MNRJ); São Paulo: Salesópolis, Est. Biol. Boracea, macho, 14-18-XI-1973, Exp. Mus. Zool. (MZSP); Ilha da Vitória, macho e 2 fêmeas, 16-27-III-1964, Exp. Mus. Zool. (MZSP); Ilha da Vitória, fêmeas, 18-XII-1918, Costa Lima leg., (MZSP); Paraná: Telêmaco Borba, Res. Samuel Klabin, malaise, macho, 27-X-1986, Lev. Ent. PROFAUPAR (DZUP); Santa Catarina: Mafra, macho, XII1959, coll. MRCN n³564, s/ col. (MCNZ); Nova Teutônia, macho, I1939, Fritz Plaumann (NMNH), Nova Teutônia, macho, 28-I-1957, Fritz Plaumann (NMNH); Nova Teutônia, $27^{\circ} 11^{\prime} \mathrm{B} 52^{\circ} 23^{\prime} \mathrm{L}, 300-500 \mathrm{~m}$, 2 macho, 14-II-1963, Fritz Plaumann (DARC); Nova Teutônia, 27¹1'B 52 $23^{\prime}$ 'L, 300-500m, 2 macho, 18-IV-1966, Fritz Plaumann (DARC); Nova Teutônia, $27^{\circ} 11^{\prime}$ B $52^{\circ} 23^{\prime} \mathrm{L}, 300-500 \mathrm{~m}$, fêmea, XI-1966, Fritz Plaumann (DARC); Nova Teutônia, $27^{\circ} 11^{\prime} \mathrm{B} 52^{\circ} 23^{\prime} \mathrm{L}, 300-500 \mathrm{~m}$, fêmea, 11-X-1969, Fritz Plaumann (DARC); Nova Teutônia, 27¹1'B 52'23'L, 300-500m, macho, 9-XI-1969, Fritz Plaumann (AMNH); Nova Teutônia, $27^{\circ} 11^{\prime}$ B $52^{\circ} 23^{\prime}$ L, 300-500m, 3 fêmea, I-1974, Fritz Plaumann (DARC); Nova Teutônia, $27^{\circ} 11^{\prime}$ B 52 $23^{\circ} \mathrm{L}, 300-500 \mathrm{~m}$, macho, II-1974, Fritz Plaumann (DARC); Nova Teutônia, 27¹1'B $52^{\circ} 23^{\prime} \mathrm{L}, 300-500 \mathrm{~m}$, fêmea, Fritz Plaumann (DARC); Rio Grande do Sul: Torres, 5 macho e 5 fêmea, $15-$ II-1974, coll. MRCN nos 8724,8726 , $8727,8728,8730,8733,8737,8739,8740,8742$ respectivamente, A. Lise col. (MCNZ); Vila Oliva, fêmea, 20-I-1961, Pe. Buck leg. col MRCN no 3567, A. Lise col. (MCNZ); Santa Maria, macho, 08-X1986, Q.J.Franceschet (UFRG); Porto Alegre, fêmea, Parque Jardim Botânico, 27-X-1997, C.F.Schwertner, (UFRG); Porto Alegre, Bairro Ipanema, fêmea, X-1997, J.A.M.Fernandes, (UFRG); BOLÍVIA. Chapare: Rio Rosquito, 1.900m, macho, 9-11-XII-1984, col. L.E. Pena (NMNH); PARAGUAI. Ciudad de Leste: macho, 19-XII-1971, Thomas F. Halstead coll. (DARC); Ciudad de Leste: macho, 17-XII1971, L. Peña (NMNH); Pirapó, fêmea, 31-XII-1971, Thomas F. Halstead coll. (DARC); Pirapó, fêmea, 1977, L.E. Peña (NMNH); ARGENTINA. Misiones: Delícia, macho, 13-XI-1964, A. Kovacs (AMNH); Eldorado, 3 machos, 19-XI-1964, A. Kovacs (AMNH); Eldorado, macho, 8-XII-1964, A. Kovacs (AMNH); Eldorado, macho, 

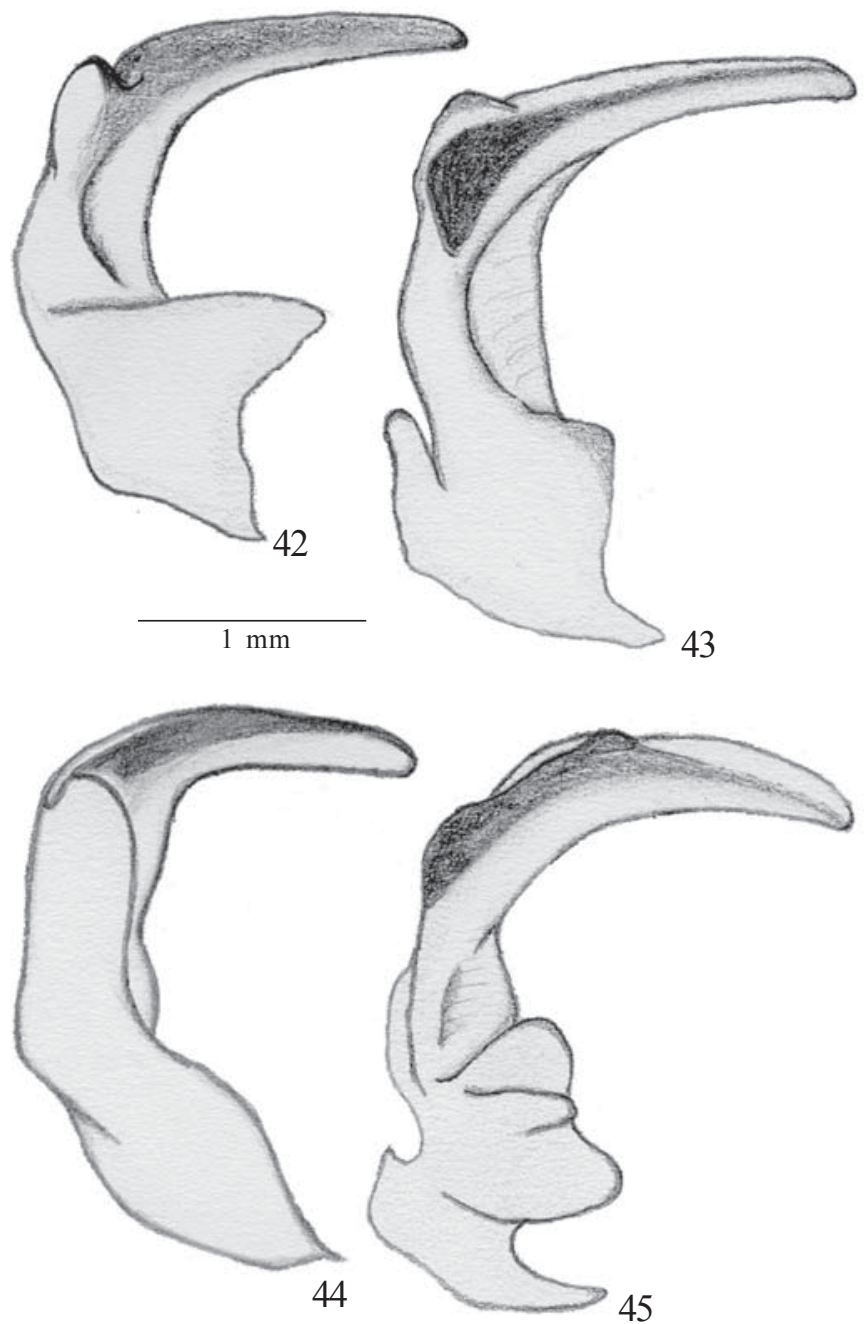

Figs. 42-45. Parâmero esquerdo, vista lateral externa. 42, Serdia beckerae; 43, S. quadridens; 44, S. delphis; 45, S. ruckesi.

L.N.Alem., XII-1961, A. Martinez leg. (MZSP); fêmea, s/ dados, 19XII-1971, (UFRG);macho, s/ dados, 21-XII-1971, (UFRG).

Comentários. S. concolor e $S$. indistincta sp. nov. formam um grupo monofilético sustentado por três sinapomorfias folheto externo do bordo ventral do pigóforo com uma única projeção, chitinellipsen dispostas posteriormente ao espessamento da íntima vaginal, espessamento da íntima vaginal totalmente esclerotizado; porém ápice do bordo dorsal do pigóforo destituído de processos e bordo ventral do pigóforo projetado dorsalmente, homoplásicos com $S$. limbatipennis e $S$. calligera + S. maculata também corroboram o parentesco destas espécies. S. concolor distingue-se morfologicamente de $S$. indistincta sp. nov. pela projeção mediana da parede ventral do pigóforo, em forma de uma pequena elevação, enquanto que em $S$. indistincta é em forma de um espinho nítido, ductus seminis distalis extremamente curto, surgindo da altura mediana do tubo cilíndrico. Nas fêmeas as diferenças são perceptíveis apenas na forma e comprimento do espessamento da íntima vaginal, sendo em $S$. concolor mais longo e estreitado na base e em $S$. indistincta mais curto e com base truncada.

Serdia indistincta sp. nov.
(Figs. 3, 20,37, 52, 69, 84)

Etimologia. Nome alusivo à uniformidade de coloração do corpo e das pontuações e à semelhança com S. concolor.

Macho. Medidas (n=17): comprimento total 13,4 (14,6-12,2) 0,3 ; largura abdominal $7,2(8,0-6,3) 0,26$; comprimento da cabeça $2,1(2,3-1,8) 0,1$; largura da cabeça $2,7(3,0-2,5) 0,1$; comprimento dos artículos antenais I $0,8(0,9-0,7) 0,1 ;$ II $0,6(0,7-0,5) 0,06$; III $1,8(1,9-1,7) 0,1$; IV 2,2 (2,3-2,0) 0,1; V 2,0 (2,1-1,9) 0,1; comprimento do pronoto $3,1(3,3-3,0) 0,1$; largura anterior do pronoto $2,9(3,5-2,6) 0,1$; largura posterior do pronoto $7,2(7,7-$ $6,8) 0,1$; comprimento do escutelo $5,4(6,0-4,8) 0,1$; largura do escutelo 4,4 (4,8-4,0) 0,1.

Descrição. Forma arredondada, coloração castanho-clara a castanho-escura, moderada a densamente pontuada, pontuações ferrugíneas uniforme e igualmente distribuídas. Cabeça levemente mais larga que longa, sinuosidade da margem ante-ocular variável dentro da espécie, ápice arredondado e estreito; jugas sobrepostas apicalmente; ocelos circundados na margem interna por pequenas pontuações castanho-escuras. Primeiro artículo antenal castanho-claro a castanho-escuro, atingindo o ápice da cabeça; $2^{\circ}$ e $3^{\circ}$ castanhoescuros a enegrecidos; quarto segmento com metade basal castanho-clara a amarelada e metade apical castanho-escura a enegrecida. Quinto artículo totalmente amarelado. Comprimento do rostro atingindo o limite anterior da carena metasternal. Pronoto com ângulos umerais retilíneos, não desenvolvidos, margens ântero-laterais subparalelas ou suavemente côncavas, estreitamente emarginadas; pontuações menores e mais densas junto as margens anteriores (estendendo-se, em alguns, até a margem anterior das cicatrizes), margens póstero-laterais, margem posterior e ao redor das cicatrizes, no restante são uniformes e igualmente distribuídas. Cicatrizes concolores a castanho-escuras. Escutelo com margem apical não emarginada e delicadamente delineada de negro nas laterais. Pontuações de tamanho variável densas e igualmente distribuídas. Hemiélitro com superfície densa e uniformemente pontuada, as pontuações atingindo a margem costal, exceto anteriormente. Célula discal pálida envolvida por uma pequena mancha escura e um pequeno calo amarelado situado acima da mancha. Superfície torácica ventral de coloração castanho-clara com pontuações ferrugíneas a castanho-escuras moderadamente densas, menores e mais concentradas nas margens ântero-laterais da propleura, margens laterais da meso e metapleura e margem posterior da metapleura; pontuações maiores e mais esparsas no restante, alguns exemplares apresentam pontuações concentradas numa faixa larga da cicatriz da propleura e do epímero da meso e metapleura. Segmentos do conexivo, em geral, expostos com superfície densamente pontuada, pontuações castanho-claras, menores ocasionalmente na 


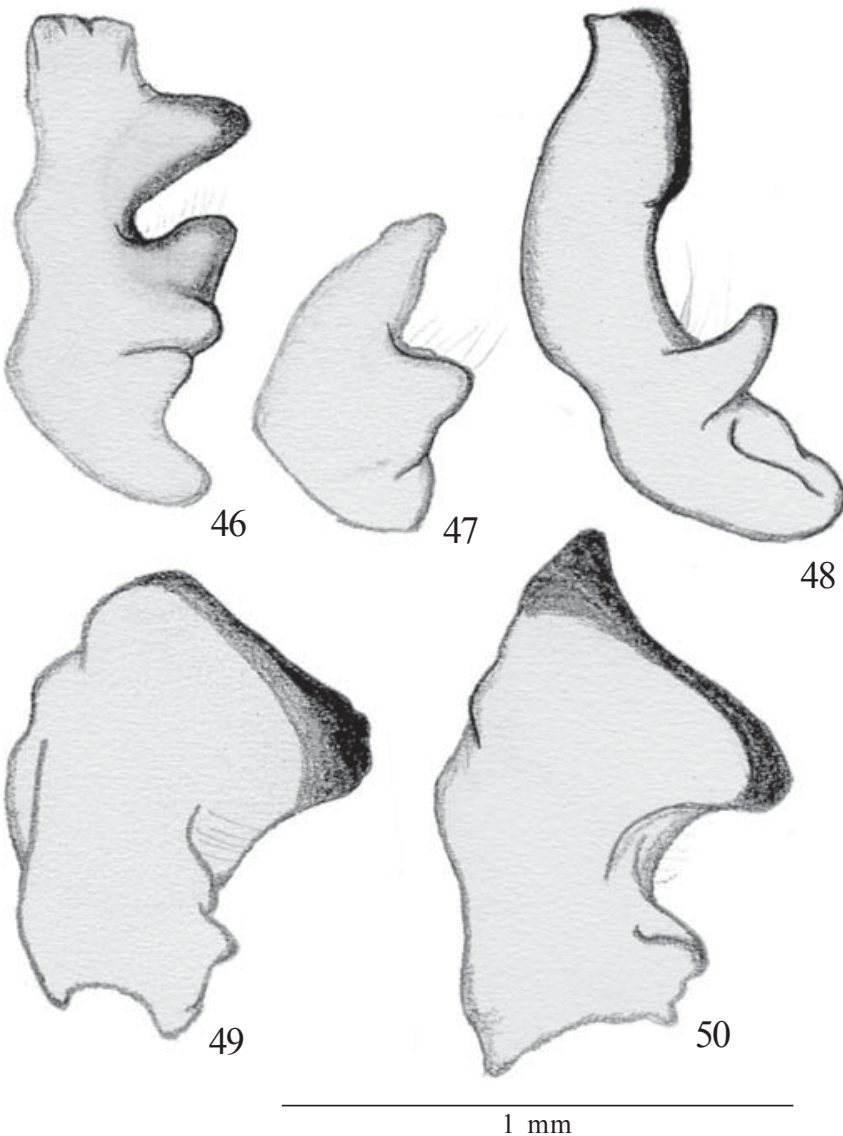

Figs. 46-50. Parâmero esquerdo, vista lateral externa. 46, Serdia maxima, sp. nov.; 47, S. apicicornis; 48, S. lobata; 49, S. calligera; 50, S. maculata, sp. nov.

margem externa de cada segmento. Ângulos póstero-laterais pequenos, negros e fortemente apiculados. Superfície ventral do abdome com pontuações castanho-clara a castanhoescuras. Espinho do terceiro segmento agudo. Pernas de coloração castanho-clara a amarelada, pontuações de cor ferrugem, moderadamente densas nos fêmures, menos densas nas tíbias; tarsos avermelhados.

Genitália. Pigóforo de contorno quadrangular, ventralmente com pontuações grosseiras castanho-claras a ferrugíneas, de tamanho variado mais densas sobre os ângulos pósterolaterais e rareando em direção ao espinho triangular mediano. Ângulos ântero-laterais com um entalhe mediano semelhante a $S$. concolor, porém menor. Bordo dorsal arredondado medianamente e destituído de processos (Fig. 3). Bordo ventral trissinuoso projetado dorsalmente e recortado em forma de "U". Parede ventral do pigóforo com uma ranhura pré-apical em "V" aberto, medianamente com um nítido espinho, coincidente com a escavação mediana do bordo ventral (Fig. 20). Décimo segmento ovalado, estreitando-se apicalmente; disposto perpendicularmente ao plano sagital (Fig. 37). Parâmeros subquadrangulares, dispostos perpendicularmente ao plano sagital, com duas projeções espatuladas semelhantes a S. concolor, porém menores (Fig. 52). Phallus. Phallotheca com 1+1 expansões laterais em forma de abas largas. Vésica semelhante a $S$. concolor com as expansões laminares um pouco mais amplas com uma cúspide terminal; porção livre do ductus seminis distalis pouco mais longa que em $S$. concolor. Gonoporo secundário circular.

Fêmea semelhante ao macho. Medidas ( $\mathrm{n}=29)$ : comprimento total 14,1 (16,8-12,1) 0,6; largura abdominal 7,3 (8,5-6,2) 0,3; comprimento da cabeça $2,2(2,8-1,8) 0,1$; largura da cabeça 2,7 $(3,0-2,4) 0,1$; comprimento dos artículos antenais I $0,7(0,9-0,6)$ 0,$1 ;$ II $0,6(0,9-0,6) 0,2$; III 1,7 (1,9-1,5) 0,1; IV 1,7 (1,9-1,5) 0,4; V $2,0(3,1-1,5) 0,2$; comprimento do pronoto $3,2(3,8-2,9) 0,1$; largura anterior do pronoto $3,0(3,5-2,5) 0,1$; largura posterior do pronoto $7,1(8,0-6,2) 0,3$; comprimento do escutelo $5,4(6,5$ 4,9) 0,2; largura do escutelo 4,3 (5,0-3,7) 0,2.

Genitália. Superfície das placas genitais densamente pontuada, pontuações ferrugíneas de tamanho variável. Sétimo segmento com a margem posterior côncava sobre os gonocoxitos 8. Forma e tamanho das placas genitais praticamente idênticas à $S$. concolor (Fig. 69), exceto o espessamento da íntima vaginal que é totalmente esclerotizado, uniforme no calibre e pouco menor que na espécie anterior. Chitinellipsen situadas posteriormente ao espessamento da íntima vaginal. Comprimento do ductus receptaculi nas regiões anterior e posterior à área vesicular, cristas anulares, pars intermedialis e capsula seminalis como descrito em $S$. concolor (Fig. 84).

Distribuição. Brasil: Minas Gerais, São Paulo, Paraná, Santa Catarina, Rio Grande do Sul; Argentina: Misiones.

Holótipo macho. BRASIL. Rio Grande do Sul: Iraí, 19-XII-1975, col. MCN no 45.127, A. Lise leg. (MCNZ). Parátipos. BRASIL. Minas Gerais: Pedra Azul, macho, XI-1970, F. M. Oliveira (AMNH); São Paulo: s/ dados, fêmea, 13-XII-1916, Costa Lima leg. (MZSP); Paraná: Jaguariaiva, macho, 24-29-XII-1970, F. Giacomel (DZUP); Ponta Grossa (Vila Velha), Reserva IAPAR Br 376, malaise, fêmea, 15-II1988, Lev. Ent. PROFAUPAR, (DZUP); Foz do Iguaçu, macho, I1962, Coll. MRCN n³566, Hüdepohl col., (MCNZ); Antonina, Reserva Sapitanduva, lâmpada, fêmea, 3-X-1986, Lev. Ent. PROFAUPAR, (DZUP); Campo Tenente, 3 fêmeas, 21-I-1974, Becker, Mielke leg., (DZUP); Santa Catarina: Nova Teutônia, fêmea, 25-V-1955, Fritz Plaumann (NMNH); Nova Teutônia, 2 fêmeas, 12-VI-1945, Fritz Plaumann (NMNH); Nova Teutônia, macho, 27-VI-1945, Fritz Plaumann (NMNH); Nova Teutônia, fêmea, 28-VI-1945, Fritz Plaumann (NMNH); Nova Teutônia, macho, 28-VI-1945, Fritz Plaumann (NMNH); Nova Teutônia, macho, 5-VII-1945, Fritz Plaumann (NMNH); Nova Teutônia, fêmea, 5-VII-1945, Fritz Plaumann (NMNH); Nova Teutônia, macho, 5-VII-1947, Fritz

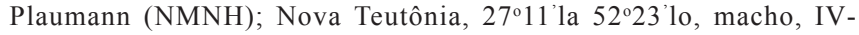
1948, Ex. coll. H. Ruckes, Fritz Plaumann leg. (AMNH); Rio Grande do Sul: Iraí, 2 machos, 18-XI-1975, coll. MRCN nos 12.818 e 12819 , A. Lise leg. (MCNZ); Iraí, 3 machos e 1 fêmea, 19-XI-1975, coll. MRCN n ${ }^{\text {os }} 12.820,45.133,45.134,45.135$, A. Lise leg. (MCNZ); Iraí, 1 macho e 4 fêmeas, 19-XII-1975, coll. MRCN n ${ }^{\text {os }} 45.128,45.129$, 45.130, 45.131, 45.132, A. Lise leg. (MCNZ); Tenente Portela, 2 machos e 2 fêmeas, 4-6-II-1980, coll. MRCN n ${ }^{\text {os }} 13.483,13.485$, 13.488, 13.491, A. Lise leg. (MCNZ); Torres, fêmea, 15-XI-1974, coll. MRCN no 8.744, A. Lise leg. (MCNZ); Santa Maria, fêmea, 12-I1971, col MRCN no 13.109, M.F.Tarrago leg., (MCNZ); São Leopoldo, fêmea, 24-IV-1987, coll. MRCN n52.825, C.J.Becker leg., (MCNZ); Porto Alegre, Ponta Grossa (Itapuã), fêmea, 3-I-1965, coll. MRCN n ${ }^{\circ}$ 3.575, s/ col., (MCNZ); Guaíba, macho, 31-X-4-XI-1979, coll. MRCN $\mathrm{n}^{\circ}$ 15.790, H.A.Gastal leg., (MCNZ); ARGENTINA. Misiones: Puerto Iguazu, fêmea, 22-XI-1989, s/col. (DARC); Puerto Iguazu, macho, 30- 


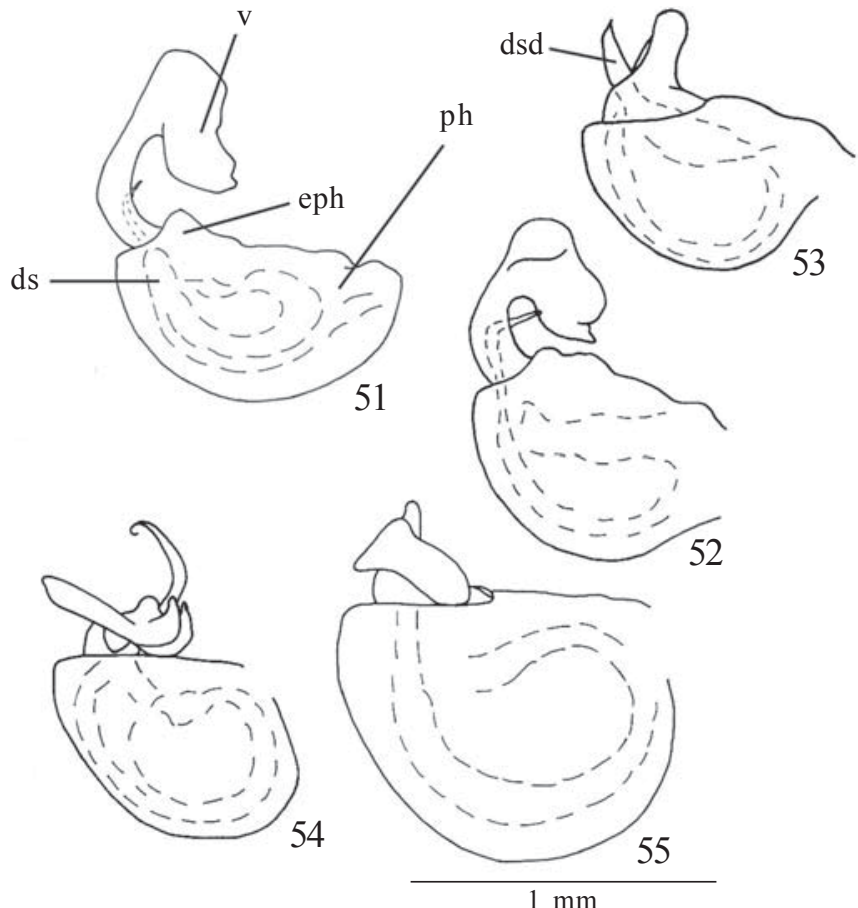

Figs. 51-55. Phallus, vista lateral. 51, Serdia concolor; 52, S. indistincta, sp. nov.; 53, S. bihamulata; $54, S$. rotundicornis; 55, S. limbatipennis; $\mathrm{ds}=d u c t u s$ seminis, $\mathrm{dsd}=d u c t u s$ seminis distalis, eph=expansão da phallotheca, $\mathrm{v}=$ vésica.

XII-1991, s/col. (DARC); Eldorado, fêmea, IX-XI-1964, A. Kovacs leg. (AMNH); Eldorado, 5 fêmeas, 19-XI-1964, A. Kovacs leg. (AMNH); Eldorado, macho e fêmea, 18-XII-1964, A. Kovacs leg. (AMNH); s/ localidade, fêmea, 20-XII-1971, s/ col. (UFRG); s/ localidade, 2 fêmeas, 21-XII-1971, s/ col. (UFRG); s/ localidade, 2 fêmeas, 08-I-1972, s/ col. (UFRG); s/ localidade, macho, 21-I-1972, s/ col. (UFRG).

Comentários. Vide em S. concolor.

Serdia beckerae Thomas \& Rolston, 1985 (Figs. 9, 26, 42, 56, 70, 85, 116)

Serdia (Serdia) beckeri [sic] Thomas \& Rolston, 1985: 1165 (descrição, chave).

Macho. Medidas ( $\mathrm{n}=1)$ : comprimento total 13,1; largura abdominal 6,7; comprimento da cabeça 2,2; largura da cabeça 2,9; comprimento dos artículos antenais I 0,7; II 0,7; III 1,6; IV 2,1; V falta; comprimento do pronoto 3,2; largura anterior do pronoto 3,0; largura posterior do pronoto 6,7 ; comprimento do escutelo 5,4; largura do escutelo 4,0.

Descrição. Forma arredondada de coloração castanha, pontuações castanho-escuras densas e uniformemente distribuídas. Cabeça com ápice fortemente estreito, margem anteocular sutilmente sinuosa, com jugas não contíguas, terço apical fendido. Segmentos antenais do $1^{\circ}$ ao $4^{\circ}$ castanho-claros, densamente pontuados, $1^{\circ}$ artículo ultrapassando o ápice da cabeça. Rostro atingindo a metade do metasterno. Pronoto com úmeros em ângulo obtuso, levemente desenvolvidos mas de comprimento menor que a distância entre os olhos, margens ântero-laterais emarginadas, levemente refletidas, dispersamente bordeadas com longas setas. Cicatrizes concolores. Escutelo com margem apical não emarginada e com bordos laterais delineados de negro. Hemiélitro densamente pontuado, freno e veia radial com 1+1 linhas parelalas de pontuações intercaladas por uma linha subcalosa destituída de pontuação. Célula discal pequena, esbranquiçada e sutilmente conspícua. Superfície torácia ventral de coloração castanho-amarelada; pontuações densas, castanho-escuras e mais esparsas que no dorso. Segmentos do conexivo parcial ou totalmente recobertos, densamente pontuados, coloração castanha com pontuações castanho-escuras. Ângulos póstero-laterais apiculados e enegrecidos. Superfície ventral do abdome de coloração castanha, pontuações castanhoescuras. Espinho mediano do $3^{\circ}$ segmento abdominal alongado, agudo e atingindo a metade das metacoxas. Pernas de coloração castanho-claro a amarelado, principalmente nas tíbias e tarsos, dispersamente pontuados com pontuações castanhas.

Genitália. Pigóforo de contorno quadrangular com longos pêlos moderadamente densos no bordo ventral próximo aos ângulos póstero-laterais, estes arredondados. Bordo dorsal côncavo, medianamente com $1+1$ processos tuberculados, enegrecidos no ápice (Fig. 9). Bordo ventral côncavo, folheto superior medianamente em "V" aberto com $1+1$ pequenas projeções laminares escurecidas de cada lado; folheto inferior com 1+1 processos denticulados, em forma de "V" aberto com ápice amarelado (Fig. 26). Décimo segmento retangular, disposto perpendicularmente ao plano sagital, piloso, principalmente na superície apical, onde as setas são mais longas (Fig. 9). Parâmeros dispostos perpendicularmente ao plano sagital, delgados, com 1+1 processos diferenciados, um lateral curto e lobado, ápice amarelado e outro apical com uma projeção longa, digitiforme, curvada em direção ao ápice. Superfície dorsal enegrecida (Fig. 42). Phallus. Vésica em tubo cilíndrico pequeno, de ápice recurvado, com cerca de $1 / 3$ do comprimento da phallotheca, com $1+1$ processos longos subcilíndricos, mais largos apicalmente e projetados em direção a placa basal, extremidades apicais bifurcadas. Ductus seminis distalis encoberto pelos processos da vésica, em vista lateral. Gonoporo secundário em calha (Fig. 56).

Fêmea semelhante ao macho. Medidas $(\mathrm{n}=1)$ : comprimento total 14,8; largura abdominal 7,2; comprimento da cabeça 2,4; largura da cabeça 2,7; comprimento dos artículos antenais I 0,7; II 0,6; III 1,7; IV 2,0; V falta; comprimento do pronoto 3,0; largura anterior do pronoto 2,9; largura posterior do pronoto 6,7; comprimento do escutelo 5,9; largura do escutelo 4,0.

Genitália. Superfície das placas genitais amarelada, pontuações moderadamente densas e com longos pêlos. Sétimo segmento com margem posterior côncava sobre os gonocoxitos 8 . Laterotergitos 8 triangulares subiguais em comprimento aos laterotergitos 9 , bordo posterior ponteagudo. Laterotergitos 9 com ápice arredondado e ultrapassando nitidamente a banda que une dorsalmente os laterotergitos 8 . 
Gonocoxitos 8 de comprimento longitudinal subigual aos laterotergitos 9, margem posterior convexa; bordos suturais paralelos em toda a sua extensão (Fig. 70). Gonapófise 9 com espessamento da íntima vaginal parcialmente esclerotizado em anel incompleto, circundando o orificium receptaculi. Chitinellipsen localizadas lateralmente ao espessamento da íntima vaginal. Comprimento do ductus receptaculi na região anterior a área vesicular com 1,5 vezes o comprimento do ductus na região posterior a mesma área. Cristas anulares convergentes, pars intermedialis estreita. Capsula seminalis com três dentes recurvos, surgindo da porção médio-basal e ultrapassando a crista anular anterior em metade de seu comprimento (Fig. 85).

Distribuição: Costa Rica: Monteverde; Panamá: Chiriqui; Venezuela: Distrito Federal.

Material examinado. Holótipo macho, com as etiquetas: a) Panamá: Chiriqui, Dist. Renacimiento, Santa Clara, 4.000', V-23-26-1977; b) Holotype Serdia beckeri (AMNH). Parátipo. COSTA RICA. Monteverde: Cloud For. Res., macho, 27-V a 31-V-1984, Riley, Rider \& Le Doux (DARC). VENEZUELA. Distrito Federal: Pico del Avila: fêmea, 29VIII-1965, J. \& B. Bechyne (IZAV).

Comentários. Junto com $S$. quadridens, $S$. delphis e $S$. ruckesi, formam um grupo monofilético sustentado por duas sinapomorfias: parâmeros com uma projeção longa e curva e vésica com $1+1$ expansões subcilíndricas ou digitiformes, projetadas dorsalmente. Tufo de pêlos longos na parede ventral do pigóforo junto aos ângulos póstero-laterais, terço mediano do bordo dorsal do pigóforo com processos, margem posterior dos laterotergitos 8 projetada em forma triangular e laterotergitos 9 ultrapassando nitidamente a banda que une dorsalmente os laterotergitos 9 são caracteres homoplásicos que corroboram o parentesco deste grupo. S. beckerae se diferencia de todas as espécies do gênero, tipologicamente, pelas pontuações dos hemiélitros, dispostos em 1+1 linhas paralelas intercaladas por uma linha subcalosa destituída de pontuação, localizadas externamente ao freno e à veia radial e pelos folhetos inferior e superior do bordo ventral em forma de "V" amplamente aberto. Deduzindo que o nome da espécie descrita por Thomas \& Rolston (1985) foi em homenagem à Dra Miriam Becker, o epíteto específico, de acordo com o Código Internacional de Nomenclatura Zoologica (ICZN 1999) deve ser S. beckerae.

Serdia quadridens Thomas \& Rolston, 1985 (Figs. 10, 27, 43, 57)

Serdia (Serdia) quadridens Thomas \& Rolston, 1985: 1165 (descrição, chave).

Macho. Medidas ( $\mathrm{n}=3)$ : comprimento total 12,9 $(13,6-12,3)$ 0,4 ; largura abdominal $7,6(8,1-7,2) 0,3$; comprimento da cabeça $2,4(2.5-2.1) 0,2$; largura da cabeça $3,0(3,2-2,9) 0,1$; comprimento dos artículos antenais I $0,5(0,7-0,4) 0,2$; II $0,4(0,5-0,3) 0,1$; III $1,4(2,1-1,0) 0,7$; IV 2,1; V 2,7; comprimento do pronoto 3,3 (3,4$3,2) 0,1$; largura anterior do pronoto $3,2(3,4-3,0) 0,1$; largura posterior do pronoto $7,6(8,1-7,2) 0,3$; comprimento do escutelo
5,7 (6,0-5,4) 0,2; largura do escutelo 4,6 (4,9-4,4) 0,2.

Descrição. Forma ovalada, de coloração castanho-escura, densa e uniformemente pontuada, pontuações castanhas. Cabeça com ápice estreito, margem anteocular levemente sinuosa, jugas contíguas, segmentos antenais de coloração castanho-escura com pontuações castanhas nos artículos $1^{\circ}$ e $2^{\circ}$, ausentes nos artículos restantes. Primeiro artículo ultrapassando o ápice da cabeça. Rostro atingindo a metade do metasterno. Pronoto com ângulos umerais estreitamente arredondados e levemente desenvolvidos mas de comprimento menor que a distância entre os olhos. Margens ântero-laterais levemente côncavas, crenuladas e emarginadas suportando esparsas franjas de setas moderadamente longas. Cicatrizes concolores. Escutelo com margem apical do escutelo não emarginada e com bordos laterais escuros. Superfície torácica ventral de coloração amarelo-escura a castanha, pontuações castanho-escuras densas, de tamanho variável e mais espalhadas que no dorso. Segmentos do conexivo praticamente encobertos restando visível apenas a linha marginal do $3^{\circ}$ ao $7^{\circ}$ segmentos. Coloração castanho-escura com pontuações escuras moderadamente densas semelhantes a superfície ventral do abdome. Ângulos póstero-laterais sutilmente apiculados e enegrecidos. Superfície ventral do abdome de coloração castanha com o espinho mediano do $3^{\circ}$ segmento abdominal agudo. Pernas de coloração ocre, pontuações de cor ferrugem, conspícuas e grosseiras nos fêmures, menos densas nas tíbias.

Genitália. Pigóforo de contorno quadrangular, com densos e longos pêlos no bordo ventral próximo aos ângulos pósterolaterais, estes moderadamente arredondados. Bordo dorsal bissinuoso, medianamente côncavo com $1+1$ projeções convexas de cada lado e $1+1$ processos tuberculares, enegrecidos no ápice, localizados próximo aos ângulos póstero-laterais (Fig. 10). Bordo ventral medianamente com o folheto superior apresentando $1+1$ processos digitiformes, ápice enegrecido e folheto inferior com $1+1$ processos digitiformes de ápice amarelado. Décimo segmento perpendicular ao plano sagital de formato retangular e piloso, principalmente na superfície apical, onde as setas são mais longas (Fig. 10). Parâmeros delgados, dispostos perpendicularmente ao plano sagital e com uma projeção extremamente alongada e curva com um tufo de pêlos presentes na face interna basal. Superfície apical curvada dorsalmente em "cotovelo" e escurecida em faixa estreita até o ápice do parâmero (Fig. 43). Phallus. Vésica em tubo cilíndrico pequeno, cerca de $1 / 3$ do comprimento da phallotheca com $1+1$ processos anteriores longos, sinuosos, subcilíndricos e projetados em direção à placa basal; extremidades apicais bifurcadas e convergentes. Ductus seminis distalis com cerca de $1 / 3$ do comprimento dos processos da vésica. Gonoporo secundário em calha (Fig. 57).

Fêmea desconhecida.

Distribuição. Peru: La Libertad e Cuzco.

Material examinado. Holótipo macho, com as etiquetas: a) Peru, Dpto. La Libertad Cumpang; above Uctubamba, 2625m, 13-X-1979, L. J. Barkley; b) Holotype Serdia quadridens (AMNH). Parátipo. 


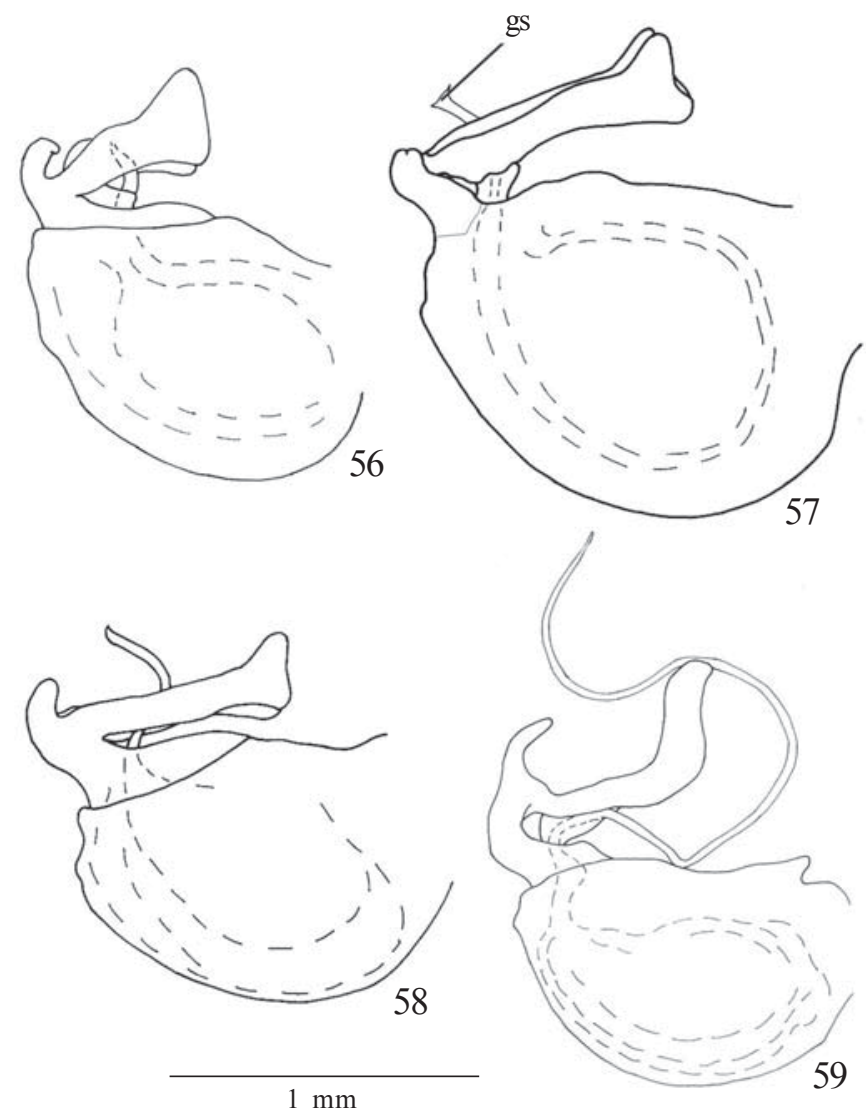

Figs. 56-59. Phallus, vista lateral. 56, Serdia beckerae; 57, S. quadridens; 58, S. delphis; 59, S. ruckesi; gs=gonoporo secundário.

PERU. La Libertad: Cumpang, above Uctubamba, 2.625m, macho, 16-X-1979, L. J. Barkley (DARC). PERU. Cusco: Paucartambo, Pillahuata, 2.800mts., macho, XII-1952, F. Woytkowski, J.C. Lutz Collection 1961 (NMNH).

Comentários. O grupo S. quadridens ${ }^{+}$tem seu parentesco embasado pela forma ovalada do corpo, homoplásico com Tibilis e $S$. rotundicornis ${ }^{+}$. A espécie $S$. quadridens distinguise de todas as espécies do gênero, tipicamente, pelos processos digitiformes dos folhetos inferior e superior do bordo ventral do pigóforo nitidamente mais desenvolvidos e mais próximos entre si.

Serdia delphis Thomas \& Rolston, 1985 (Figs. 11, 28, 44, 58, 71)

Serdia (Serdia) delphis Thomas \& Rolston, 1985: 1165 (descrição, chave).

Macho. Medidas ( $\mathrm{n}=3)$ : comprimento total 12,9 $(13,4-12,4)$ 0,7 ; largura abdominal 6,4 (6.7-6.5) 0.07 ; comprimento da cabeça $2,2(2.5-2.1) 0.1$; largura da cabeça 2,7 (2.7-2.7) 0.0 ; comprimento dos artículos antenais I $0,7(0,9-0,8) 0,06$; II $0,7(0,8-0,7) 0,1$; III 1,9; IV 2,4; V 2,5; comprimento do pronoto 3,2 (3.2-3.2) 0.0 ; largura anterior do pronoto $2,9(3.0-2.8) 0.2$; largura posterior do pronoto $6,7(6,9-6,6) 0,2$; comprimento do escutelo 5,4 (5,7$5,0) 0,4$; largura do escutelo $3,9(4,0-3,9) 0,12$.

Descrição. Forma arredondada, coloração castanhoamarelada. Pontuações menores que nas outras espécies, moderadamente densas. Cabeça fortemente estreitada no ápice, margem anteocular sutilmente sinuosa, jugas não contíguas, terço apical fendido. Pontuações testáceas, numerosas nas jugas, clípeo e disco da cabeça, em alguns exemplares formando uma linha de pontos que acompanha as margens internas e externas das jugas, de onde partem inúmeras rugas transversais. Artículos antenais avermelhados, $1^{\circ}$ ultrapassando o ápice da cabeça, levemente manchado assim como o $2^{\circ} ; 5^{\circ}$ amarelado. Rostro ultrapassando a margem anterior mas não atingindo o meio do metasterno. Pronoto com úmeros subangulares, pontuações dorsais do pronoto moderadamente densas e ferrugíneas, levemente mais concentradas próximo as margens ântero-laterais, estas não emarginadas, levemente côncavas em vista dorsal e com uma estreita faixa amarelada ou avermelhada suportando esparsas franjas de longas setas. Cicatrizes concolores. Escutelo uniformemente pontuado no disco, terço apical marfim com raras pontuações, margem apical subacuminada, não emarginada e com bordos laterais claros. Hemiélitro com pontuações pequenas concentradas principalmente em torno da sutura claval e da veia radial; moderadamente densas no restante e de coloração castanho-clara. Célula discal pequena, esbranquiçada e sutilmente conspícua. Superfície torácica ventral de coloração castanho-clara com pontuações castanhas, moderadamente densas de tamanho maior no disco próximo as coxas, diminuindo gradativamente até as margens laterais. Segmentos do conexivo totalmente recobertos, coloração castanho-amarelada com esparsas pontuações castanho-escuras. Ângulos póstero-laterais nitidamente apiculados do $4^{\circ}$ ao $7^{\circ}$ segmentos. Superfície ventral do abdome de coloração castanho-clara com pontuações castanhas. Espinho mediano do $3^{\circ}$ segmento abdominal largamente agudo apicalmente. Pernas de coloração avermelhada, principalmente nas tíbias e tarsos, dispersamente pontuadas, estas castanhas.

Genitália. Pigóforo de contorno quadrangular, com longos pêlos moderadamente densos no bordo ventral próximo aos ângulos póstero-laterais, estes arredondados. Bordo dorsal côncavo, medianamente com $1+1$ processos tuberculados, enegrecidos no ápice (Fig. 26). Bordo ventral côncavo com 1+1 processos tuberculados no folheto externo, ápice enegrecido. Folheto interno, medianamente com $1+1$ processos denticulados. Décimo segmento retangular disposto perpendicularmente ao plano sagital e piloso, principalmente na superfície apical, onde as setas são mais longas (Fig. 11). Parâmeros delgados, dispostos perpendicularmente ao plano sagital e com $2+2$ processos diferenciados, um lateral amarelado de ápice lobado e outro com uma projeção alongada, sinuosa e enegrecida dorsalmente (Fig. 44). Phallus: Vésica em tubo cilíndrico pequeno, com cerca da metade do comprimento da phallotheca com um par de processos longos, subcilíndricos, projetados em direção a placa basal, extremidades apicais bifurcadas em "V" aberto voltadas obliquamente uma para a 

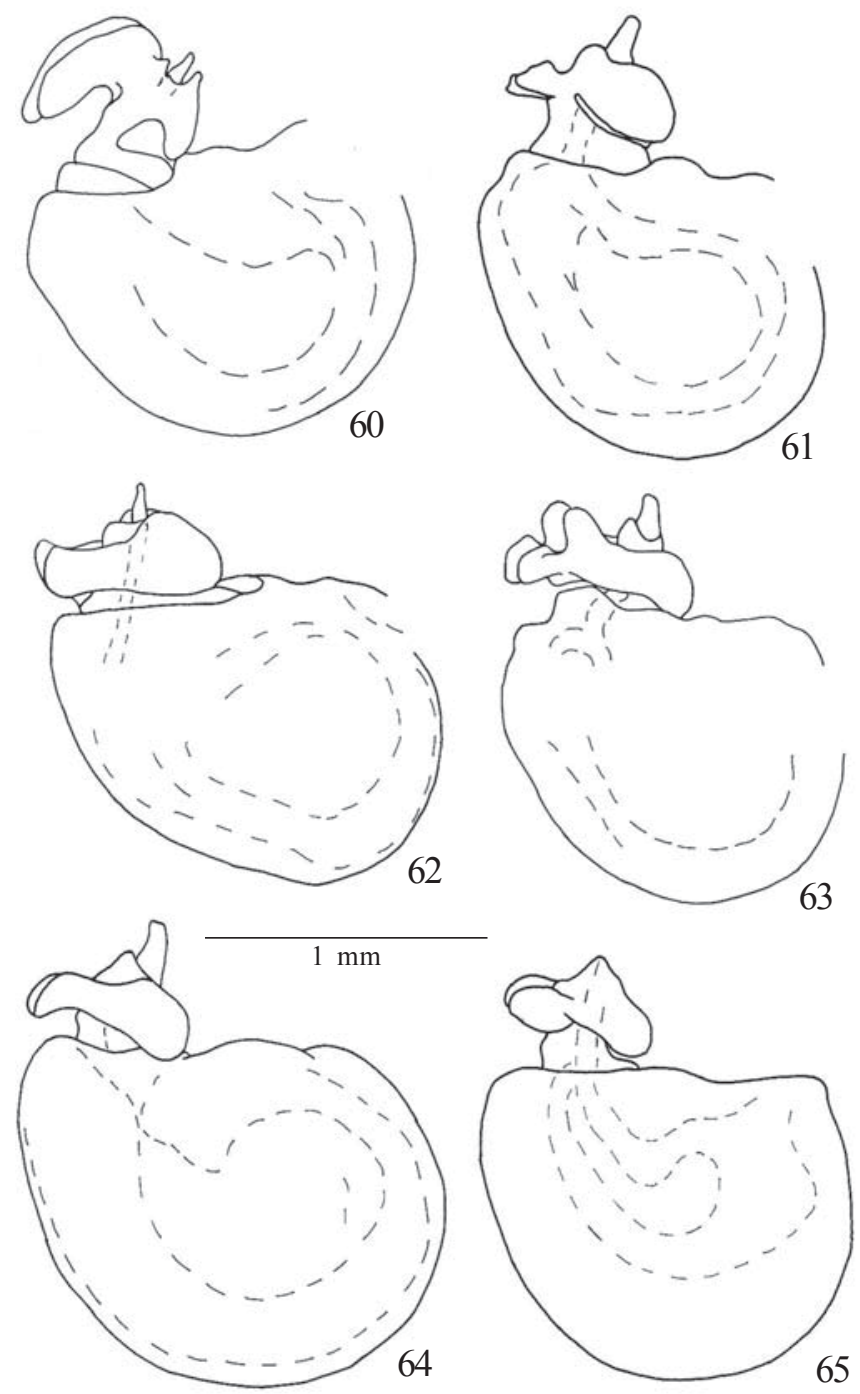

Figs. 60-65. Phallus, vista lateral. 60, Serdia inspersipes; 61, S. maxima, sp. nov.; $62, S$. apicicornis; $63, S$. lobata $; 64, S$. calligera; $65, S$. maculata, sp. nov.

outra em vista dorsal. Ductus seminis distalis, com metade do comprimento dos processos da vésica. Gonoporo secundário em calha (Fig. 58).

Fêmea semelhante ao macho. Medidas ( $\mathrm{n}=2)$ : comprimento total 12,6 (12,9-12,2) 0,2 ; largura abdominal 7,3 (7,3-7,2) 0,07 ; comprimento da cabeça $2,1(2,1-2,0) 0,07$; largura da cabeça 2,6 (2,6-2,5) 0,07; comprimento dos artículos antenais I $0,8(0,9-$ $0,8) 0,07$; II 0,57 ; III 1,6 (1,6-1,5) 0,07 ; IV 1,8; V falta; comprimento do pronoto $2,7(3,0-2,5) 0,2$; largura anterior do pronoto 3,0 ; largura posterior do pronoto $6,8(7,2-6,3) 0,4$; comprimento do escutelo 5,4 (5,8-5,0) 0,3; largura do escutelo 3,9 (4,2-3,7) 0,2.

Genitália. Superfície das placas genitais densamente pontuada, pontuações ferrugíneas. Sétimo segmento com margem posterior côncava sobre os gonocoxitos 8 . Laterotergitos 8 triangulares, de comprimento subigual aos laterotergitos 9 , bordo posterior ponteagudo. Laterotergitos 9 com margem apical arredondada e convergente. Gonocoxitos 8 convexos, disco de cada gonocoxito projetado posteriormente e de coloração castanha, bordos suturais justapostos em toda a sua extensão (Fig. 71).

Distribuição: Colômbia: Santander; Peru: Huan; Equador: Tungurahua; Bolívia: Cochabamba.

Material examinado. Holótipo macho, com as etiquetas: a) Mt. Tungurahua, III:4:37, Ecuad; b) Col. by Wm. Clarke-MaIntyre; c) Chaupi $300 \mathrm{~m}$; d) Chicago N.H. Mus. Collection (ex. W.J. Gerhard Colln.); e) Holotype Serdia delphis (AMNH). Parátipo. EQUADOR. Tungurahua: Chaupi, 300m, fêmea, 4-III-1937, Wm. Clarke-MacIntyre col. (CASM). COLÔMBIA. Santander, 32Km, East Bucaramanga, fêmea, 10-VII-1982, Clark \& Cave (DARC); PERU. Huan: Carpish, $2.800 \mathrm{~m}$, macho, X-1946, F. Woytkowski Coll. - Donor Wm. Procter (AMNH); BOLÍVIA. Cochabamba: Carrasco, Bibéria, 1650m, macho, XII-1963, Waiz leg. (DARC).

Comentários. S. delphis estabelece parentesco com $S$. ruckesi pelo ápice do escutelo de coloração clara e distinguese de todas as espécies do gênero, morfologicamente, pelas margens ântero-laterais do pronoto com uma estreita faixa amarelada ou avermelhada. Processos do folheto superior e inferior do bordo ventral do pigóforo são de tamanho intermediário entre $S$. beckerae e S. quadridens.

\section{Serdia ruckesi Thomas \& Rolston, 1985}

(Figs. 12, 29, 45, 59, 66, 67, 118)

Serdia (Serdia) ruckesi Thomas \& Rolston, 1985: 1165 (descrição, chave).

Macho. Medidas ( $\mathrm{n}=2)$ : comprimento total 13,9 $(14,2-13,6)$ 0,2 ; largura abdominal 7,6 (7,7-7,5) 0,07; comprimento da cabeça $2,3(2,5-2,1) 0,1 ;$ largura da cabeça $3,0(3,0-3,0) 0,0$; comprimento dos artículos antenais I $0,6(0,7-0,4) 0,2 ;$ II $0,5(0,7-0,4) 0,2$; III $1,6(2,0-1,1) 0,7$; IV 2,4; V 2,9; comprimento do pronoto 3,7 ; largura anterior do pronoto $3,2(3,3-3,1) 0,07$; largura posterior do pronoto $7,9(8,0-7,7) 0,1$; comprimento do escutelo 6,3 ; largura do escutelo 4,6 (4,7-4,5) 0,07 .

Descrição. Forma ovalada, coloração castanho-olivácea com áreas claras na faixa longitudinal mediana da cabeça e na faixa transversal mediana do pronoto. Superfície densa e uniformemente pontuada. Cabeça com margem anteocular sutilmente sinuosa, ápice fortemente estreito, jugas contíguas, margens internas e externas destas com uma faixa amarelada irregular e outra longitudinal mediana na cabeça. Ocelos levemente delineados de negro na margem posterior. Superfície castanha com uma faixa mediana, levemente sinuosa de cor amarelada, alargada na base e estreitando-se no ápice. Primeiro segmento antenal ultrapassando o ápice da cabeça, de cor amarelo-escuro bem como o $2^{\circ} \mathrm{e} \mathrm{o} 3^{\circ}$ segmentos, $4^{\circ}$ com mais de $2 / 3$ apicais escuros e $5^{\circ}$ segmento escurecido a $1 / 5$ da base até $2 / 5$ do ápice. Rostro atingindo a margem anterior do metasterno. Pronoto com úmeros obtusamente angulares, não desenvolvidos, margens ântero-laterais sub-retilíneas, não emarginadas e com uma linha irregular de pontuações grosseiras, esparsamente orladas com longos pêlos. Superfície castanha com uma faixa transversal mediana de coloração 


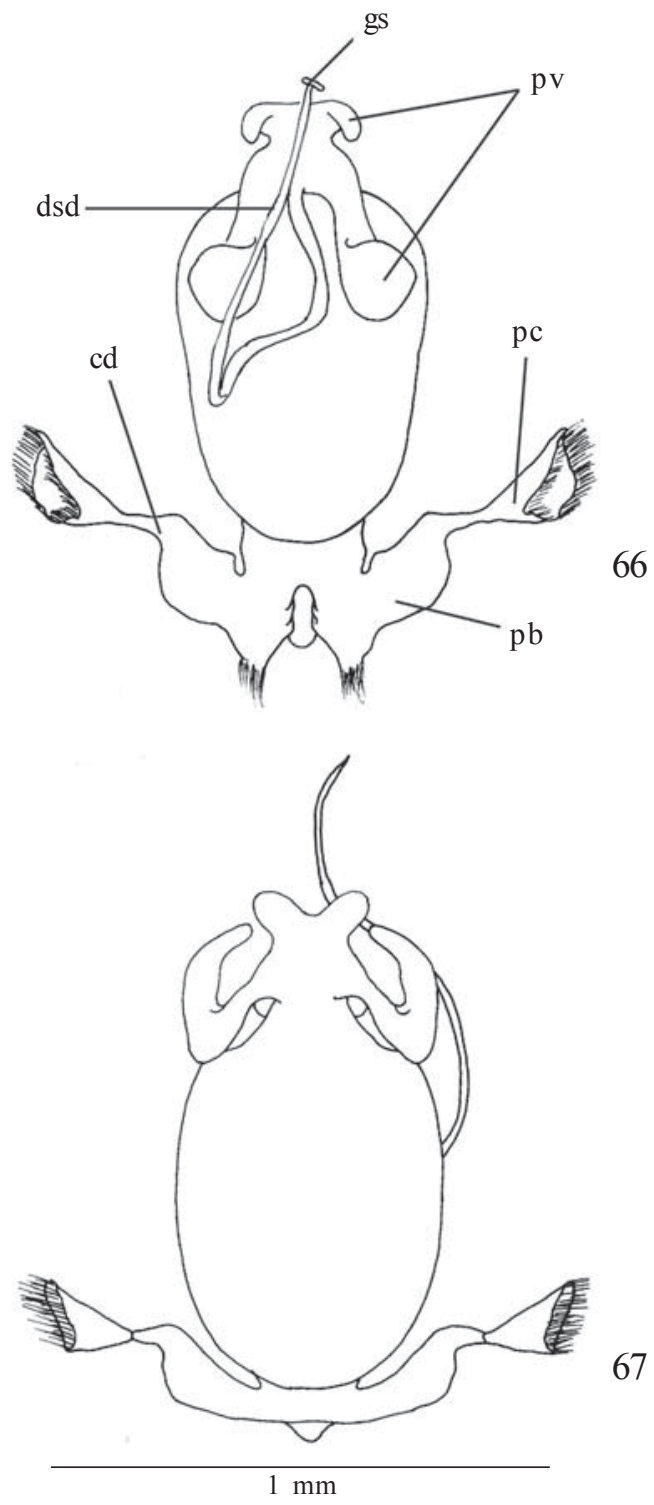

Figs. 66-67. Phallus de S. ruckesi. 66, vista dorsal; 67, vista ventral; $\mathrm{cd}=$ conectivos dorsais, $\mathrm{dsd}=$ ductus seminis distalis, $\mathrm{gs}=$ gonoporo secundário, $\mathrm{pb}=\mathrm{placa}$ basal, $\mathrm{pc}=$ processus capitati, $\mathrm{pv}=$ processos $\mathrm{da}$ vésica.
Superfície ventral do abdome moderadamente pontuada, pontuações ferrugíneas, espinho do $3^{\circ}$ segmento abdominal agudo. Pernas de coloração ocre, pontuações de cor ferrugem, conspícuas e grosseiras nos fêmures, menos densas nas tíbias.

Genitália. Pigóforo de formato quadrangular com densos e longos pêlos na margem posterior, principalmente no bordo ventral próximos aos ângulos póstero-laterais onde são extremamente longos e curvados em direção a região mediana do bordo (Fig. 118), ângulos póstero-laterais arredondados. Bordo dorsal largamente côncavo medianamente com 1+1 processos tuberculados, enegrecidos no ápice (Fig. 12). Bordo ventral levemente côncavo medianamente, com $1+1$ projeções convexas. Décimo segmento retangular disposto perpendicularmente ao plano sagital, escurecido e densamente piloso na base, diminuindo posteriormente (Fig. 12). Parâmeros situados perpendicularmente ao plano sagital, delgados com uma projeção extremamente longa e curva, metade basal com tufo de pêlos na face interna e metade apical sinuosa; rugosa e curvada dorsalmente (Fig. 45). Phallus. Vésica em tubo cilíndrico pequeno de ápice bifurcado e recurvado com $2+2$ processos subcilíndricos, longos e recurvados, extremidade apical dobrada em gancho. Ductus seminis distalis duas vezes mais longo que os processos da vésica. Gonoporo secundário em calha (Figs. 59, 66 e 67).

Fêmea desconhecida.

Distribuição. Peru: Quito, Cajamarca e La Libertad.

Material examinado. Holótipo macho, com as etiquetas: a) Peru, Dpto. La Libertad Cumpang, above Uctubamba, 2.625m, 16-X-1979, L.J. Barkley; b) Holotype, Serdia ruckesi (AMNH). Parátipo. PERU. Cajamarca: "Baton to Manchete" on Zapalche - Carmen, trail, 22502050m, macho, 14-VI a 9-VII-1980, D.A. Rider Collection (DARC). PERU. Quito: macho, s/ data, P.R. Uhler Collection 406 (NMNH).

Comentários. S. ruckesi apresenta o folheto externo do bordo ventral do pigóforo, medianamente destituído de projeções, caráter homoplásico com o grupo S. rotundicornis ${ }^{+}$; distingue-se das demais espécies do gênero, morfologicamente, pelo terço apical do escutelo em forma de ponta de flecha totalmente amarelado e pelas faixas amareladas medianas do pronoto.

Serdia bihamulata Thomas \& Rolston, 1985 (Figs. 6, 23, 38, 53, 106)

amarelada ao nível dos úmeros. Outra faixa amarelada, porém mais estreita, longitudinal, mediana, extendendo-se da margem anterior até quase a margem posterior do pronoto. Pontuações castanhas, menores na metade anterior, no restante levemente maiores. Cicatrizes concolores. Escutelo com terço apical nitidamente mais estreito, em forma de ponta de flecha totalmente amarelado e com raríssimas pontuações, restante moderadamente pontuado. Hemiélitro com superfície densa e uniformemente pontuada. Célula discal castanho-escura. Superfície torácica ventral de coloração castanha com pontuações ferrugíneas, moderadamente dispersas. Segmentos do conexivo apenas com as margens laterais expostas, ângulos póstero-laterais pequenos, negros e fortemente apiculados.
Serdia (Serdia) bihamulata Thomas \& Rolston, 1985: 1165 (descrição, chave).

Macho. Medidas (n=2). Comprimento do corpo 9,3 (9,7$8,9) 0,3$; largura abdominal 5,0; comprimento da cabeça 1,8 $(1,8-1,7) 0,07$; largura da cabeça $2,1(2,2-2,0) 0,07$; comprimento dos artículos antenais I $0,6(0,7-0,5) 0,1 ;$ II $0,7(0,8-0,7) 0,07$; III $1,3(1,6-1,0) 0,4$; IV 1,5; V 1,6; comprimento do pronoto 2,0 (2,2$1,8) 0,1$; largura anterior do pronoto $2,4(2,5-2,2) 0,1$; largura posterior do pronoto $5,1(5,4-4,9) 0,2$; comprimento do escutelo $3,4(3,5-3,4) 0,07$; largura do escutelo $2,9(3,0-2,7) 0,1$.

Descrição. Forma arredondada, coloração castanhoamarelada dorsalmente e castanho-escura ventralmente, 

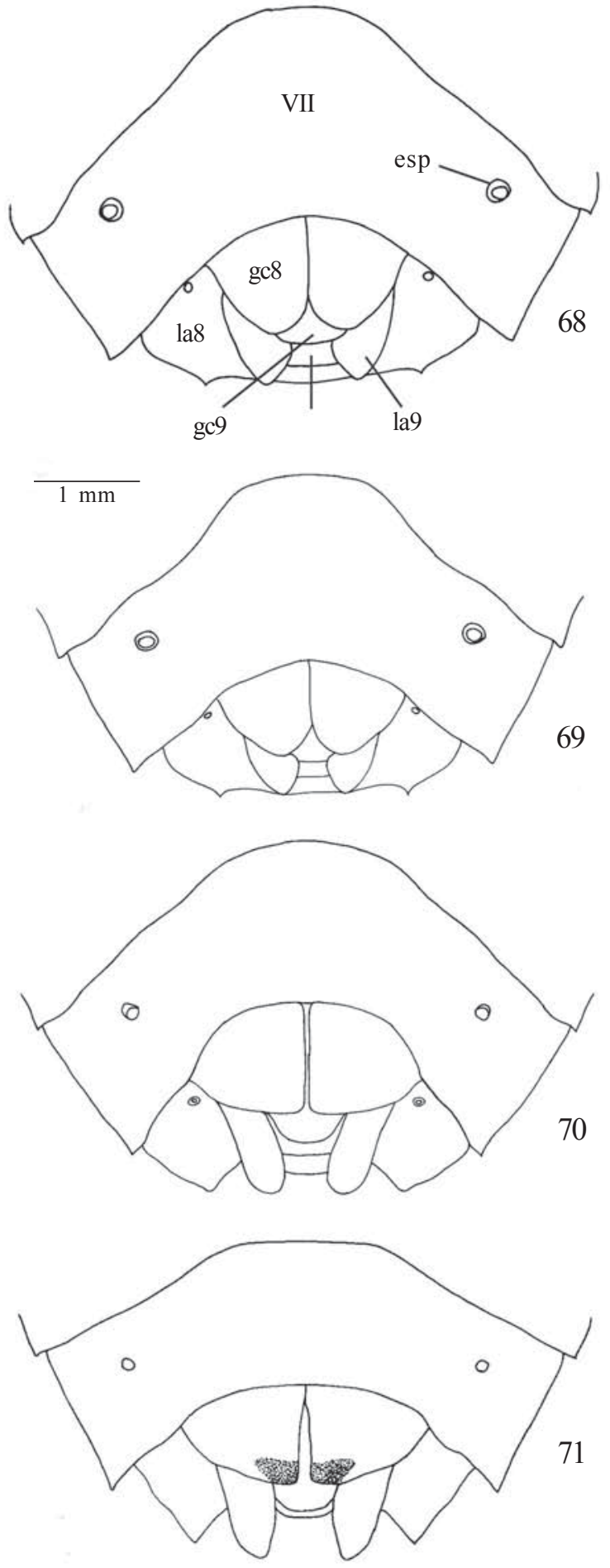

Figs. 68-71. Fêmeas: placas genitais, vista ventral. 68, Serdia concolor; 69, S. indistincta, sp. nov.; 70, S. beckeae; 71, S. delphis; esp=espiráculo, gc $8=$ gonocoxito $8, \mathrm{gc} 9=$ gonocoxito 9 , la8 $8=$ laterotergito 8, la9=laterotergito $9, \mathrm{VII}=$ sétimo segmento, $\mathrm{X}=$ décimo segmento.

pontuações dorsais densas e uniformemente distribuídas, de coloração castanho-escuras. Cabeça com margem anteocular levemente sinuosa, estreitando-se apicalmente, jugas largamente contíguas. Primeiro artículo antenal atingindo o ápice da cabeça, juntamente com o $2^{\circ}$ de coloração castanhoclaros com pontuações grosseiras e esparsas, $3^{\circ} \mathrm{e} 4^{\circ}$ artículos escuros, $4^{\circ}$ e $5^{\circ}$ amarelados. Rostro não atingindo o limite anterior do metasterno. Pronoto com ângulos umerais levemente desenvolvidos mas de comprimento menor que a distância entre os olhos, ápice moderadamente arredondado. Margens ântero-laterais emarginadas, levemente sinuosas em vista dorsal e com esparsas franjas de setas curtas (Fig. 106). Cicatrizes concolores. Escutelo com margem apical não emarginada e com os bordos laterais levemente delineados de negro. Hemiélitro com célula discal inconspícua. Superfície torácica ventral de coloração castanha a castanho-escura com densas pontuações castanho-escuras de tamanho uniforme. Segmentos do conexivo quase totalmente descoberto, ângulos póstero-laterais enegrecidos. Superfície ventral do abdome castanho-escura, densamente pontuada, pontuações castanho-escuras. Espinho do $3^{\circ}$ segmento abdominal agudo apicalmente, ângulos póstero-laterais dos esternitos não apiculados, exceto o $6^{\circ}$ e $7^{\circ}$ segmentos. Pernas de coloração castanho-clara a amarelada, moderadamente pontuadas, pontuações castanho-escuras moderadamente densas nos fêmures e esparsas nas tíbias, tarsos castanhos.

Genitália. Pigóforo quadrangular, ângulos póstero-laterais em "V". Bordo dorsal côncavo medianamente (Fig. 6). Bordo ventral sinuoso com $1+1$ projeções ântero-laterais extremamente longas, digitiformes, dirigidas dorsalmente sendo que as extremidades apicais estão voltadas para os ângulos póstero-laterais; medianamente o bordo é emarginado, subguarnecido por uma depressão semi-oval e com $1+1$ processos apiculados escuros de cada lado (Fig. 23). Décimo segmento arredondado e situado perpendicularmente ao plano sagital (Fig. 6). Parâmeros situados perpendicularmente ao plano sagital, subcilíndricos com 1+1 expansões voltadas para o mesmo lado, sendo a basal mais curta e a apical com o dobro do comprimento da anterior (Fig. 38). Phallus. Vésica em tubo cilíndrico obsoleto com expansões laminares, convergentes e subiguais em comprimento ao ductus seminis distalis. Gonoporo secundário em calha (Fig. 53).

Fêmea desconhecida.

Distribuição. Venezuela: Arágua e Miranda.

Material examinado. Holótipo macho, com as etiquetas: a) Venezuela, Aragua, Rancho Grande, 1.500m-1.900m, May, 8, 1978, O'Briens \& Marshall; b) Holotype Serdia bihamulata (AMNH). Parátipo: VENEZUELA: Miranda, Água Fria, macho, 4-IX-1959, C.J. Rosales (IZAV).

Comentários. O grupo $S$. bihamulata ${ }^{+}$é sustentado pela sinapomorfia parâmeros de forma subcilíndrica com uma ou duas projeções, estas convergentes ou não, e a homoplasia, $4^{\circ}$ artículo antenal achatado. Distingue-se, morfologicamente, das demais espécies do gênero por seu tamanho bastante reduzido; nos machos, pelas projeções ântero-laterais do bordo ventral do pigóforo extremamente longas e dirigidas dorsalmente, denominadas por Thomas \& Rolston (1985) de hâmulos. 

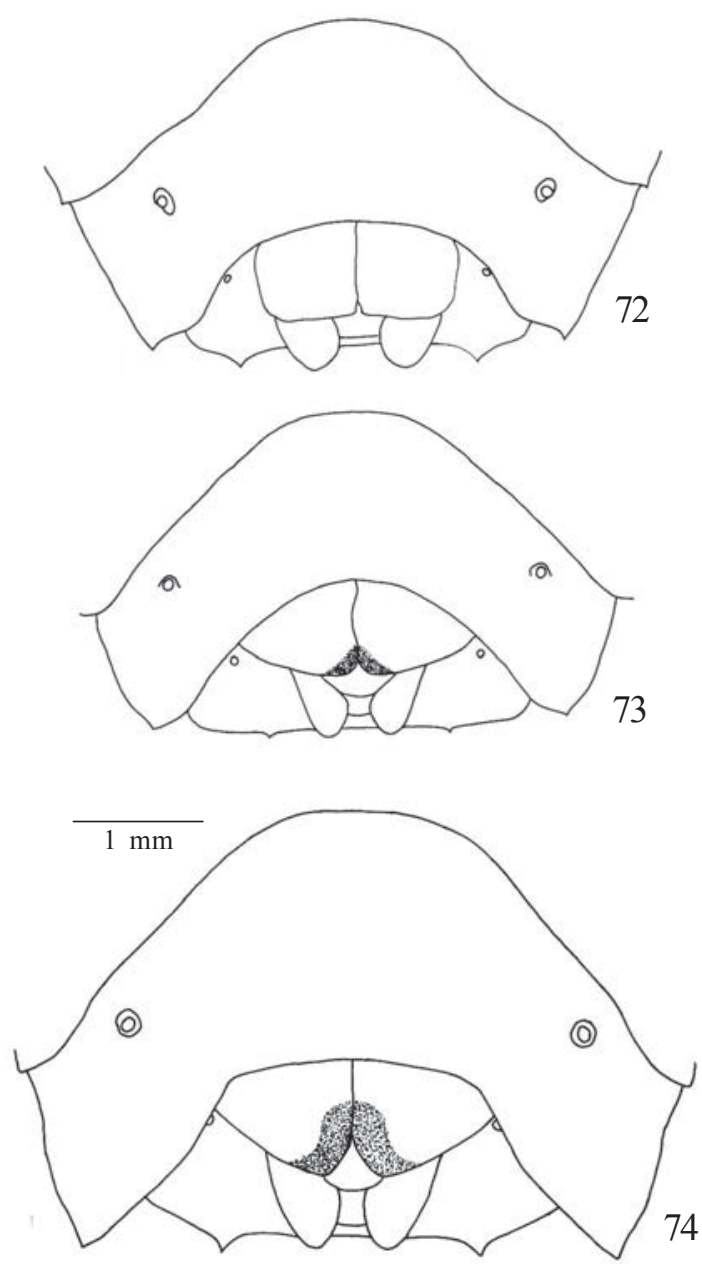

Figs. 72-74. Fêmeas: placas genitais, vista ventral. 72, Serdia rotundicornis; 73, S. limbatipennis; 74, S. bicolor, sp. nov.

\section{Serdia rotundicornis Becker, 1967}

(Figs, 7, 24, 39, 54, 72, 86)

Serdia (Serdia) rotundicornis Becker, 1967: 99 (descrição); Thomas \& Rolston, 1985: 1165 (chave).

Machos. Medidas (n=5). Comprimento total 11,4 (11,9-11,2) 0,3 ; largura abdominal $5,6(5,7-5,5) 0,08$; comprimento da cabeça $1,7(1,8-1,6) 0,11$; largura da cabeça $2,1(2,3-2,1) 0,08$; comprimento dos artículos antenais I $0,5(0,6-0,5) 0,06$; II 0,4 $(0,5-0,3) 0,1$; III $1,3(1,4-1,3) 0,12$; IV 1,4 $(1,6-1,4) 0,1$; V 1,6 (1,6$1,5) 0,1$; comprimento do pronoto $3,3(4,2-2,7) 0,5$; largura anterior do pronoto $2,6(2,6-2,5) 0,11$; largura posterior do pronoto 2,6 (2,6-2,5) 0,08; comprimento do escutelo 4,4 (4,54,3) 0,08; largura do escutelo 3,4 (3,5-3,3) 0,08.

Descrição. Forma ovalada com margens abdominais quase paralelas, levemente convergentes, margem posterior truncada; ângulos umerais do pronoto lateralmente desenvolvidos em forma auricular de contorno arredondado. Cor geral castanha a castanho-escura, pontuações castanho-escuras moderada a densas, principalmente sobre os ângulos umerais. Cabeça com margem anteocular sinuosa, jugas justapostas apicalmente, margems estreitadas progressivamente em direção ao ápice. Superfície com pontuações castanho-escuras, moderadamente densas e uniformemente distribuídas, exceto numa área circular amarelada pequena atrás dos olhos e em algumas áreas irregulares medianas próximas a base da cabeça. Ocelos circundados na margem basal por uma pequena mancha castanho-escura recoberta por pontuações. Primeiro artículo antenal amarelo pardacento, pontuado; $2^{\circ}$ ao $4^{\circ}$ progressivamente mais escuros; $4^{\circ}$ dilatado; $5^{\circ}$ totalmente âmbar. Rostro não atingindo a extremidade posterior do metasterno. Pronoto duas vezes e meia a largura ao nível dos úmeros que longo medianamente, margens ântero-laterais crenuladas, ângulos umerais desenvolvidos em projeções auriculadas de comprimento maior que a distância entre os olhos, ápice arredondado. Metade anterior de coloração castanho-claro, declivente, restante castanho-escuro. Pontuações castanho-escuras, menores e mais esparsas na metade anterior, restante tendendo a se dispor em linhas rugosas de orientação transversal ao longo da linha mediana longitudinal. Cicatrizes castanho-claras a castanho-escuras.

Escutelo com margem apical emarginada, recurva e com $1+1$ pequenas manchas negras nos bordos laterais. Pontuações castanho-escuras de tamanho variável, moderadamente densas e uniformemente distribuídas na maioria dos exemplares. Pequena área arredondada amarelada no centro da margem basal. Hemiélitro com margens do exocório amareladas, sem pontuação; área restante do exocório intensa e delicadamente pontuada; célula discal presente e amarelada. Superfície torácica ventral castanho-claro a amarelado, pontuações castanho-escuras em muito menor número que o lado dorsal, levemente densas, irregularmente distribuídas e de tamanho diferenciado. Lado inferior das expansões umerais intensa e delicadamente pontuada e de coloração mais escura que o restante. Alguns exemplares apresentam uma estreita banda longitudinal amarelada destituída de pontuação localizada nas pleuras. Carenas meso e metasternal recobertas por algumas pontuações castanhoescuras. Segmentos do conexivo estreitamente expostos, pontuações uniformemente distribuídas, concolores do $3^{\circ}$ até próximo a margem posterior do $6^{\circ}$ segmento, $7^{\circ} \mathrm{com}$ pontuações castanhas, margem posterior enegrecida. Ângulos pósterolaterais enegrecidos. Superfície ventral do abdome castanhoclaro a castanho-escuro, pontuações castanhas, espinho do $3^{\circ}$ segmento abdominal agudo. Pernas castanho amareladas, pontuações castanho-escuras moderadamente densas no fêmures e tíbias, tarsos avermelhados.

Genitália. Pigóforo de contorno arredondado, taça genital profundamente escavada, tanto dorsal quanto ventralmente. Poucas pontuações ferrugíneas menores junto ao bordo ventral, ângulos póstero-laterais côncavos em forma de "U" estreito. Bordo dorsal rasamente côncavo medianamente (Fig. 7). Bordo ventral trissinuoso, recortado em forma semiquadrangular, medianamente côncavo e com a parede interna espessa (Fig. 24). Décimo segmento ovóide disposto perpendicularmente ao plano sagital e recoberto de pêlos nas 

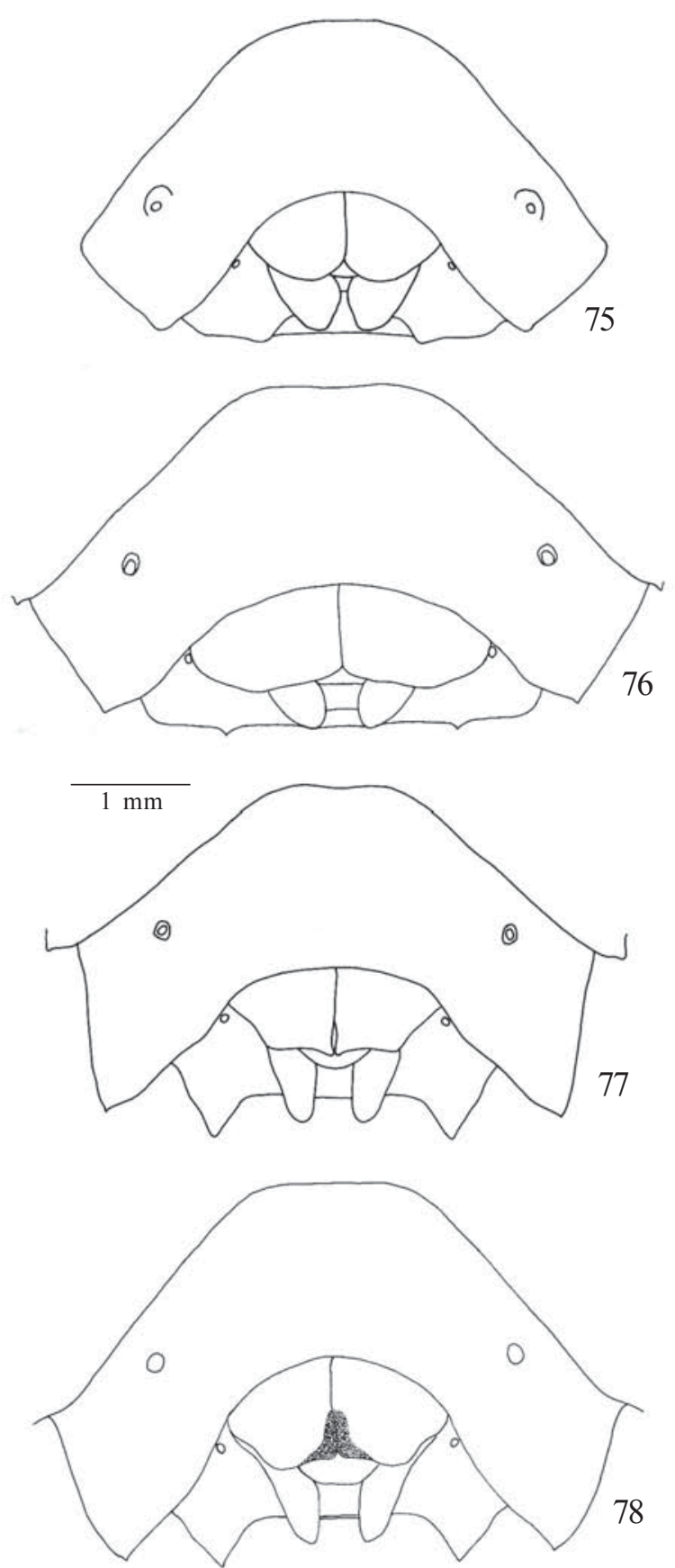

Figs. 75-78. Fêmeas: placas genitais, vista ventral. 75, Serdia inspersipes; 76, S. robusta, sp. nov.; 77, S. maxima, sp. nov.; 78, S. apicicornis.

laterais (Fig. 7). Parâmeros digitiformes, situados paralelamente ao plano sagital e três vezes mais longo que largos, margem dorsal rugosa, ápice agudo e recurvado (Fig. 39). Phallus. Vésica em tubo cilíndrico, com mais de 1/3 do comprimento da phallotheca. Processo da vésica laminar, lembrando um chapéu bávaro, posteriormente íntegro, convexo e anteriormente bífido, digitiforme, recurvada em direção ao ductus seminis distalis, este subigual, em comprimento, ao processo. Gonoporo secundário em calha (Fig. 54).

Fêmea semelhante ao macho. Medidas $(\mathrm{n}=6)$. Comprimento total $13,3(13,8-12,4) 0,3$; largura abdominal $6,7(6,9-6,2) 0,1$; comprimento da cabeça $2,1(2,4-1,8) 0,1$; largura da cabeça 2,5 $(2,9-2,4) 0,1$; comprimento dos artículos antenais $0,5(0,6-0,4)$ 0,$1 ;$ II $0,4(0,5-0,2) 0,1$; III $1,6(1,7-1,5) 0,2 ;$ IV $1,5(1,7-1,3) 0,2$; V $1,5(1,6-1,5) 0,1$; comprimento do pronoto $3,1(3,4-2,7) 0,2$; largura anterior do pronoto $2,9(3,2-2,7) 0,1$; largura posterior do pronoto $7,8(8,7-6,7) 0,4$; comprimento do escutelo $5,2(5,5-$ 4,7) 0,2 ; largura do escutelo $4,0(4,2-3,9) 0,1$.

Genitália. Superfície moderadamente pontuada, pontuações castanho-escuras. Sétimo segmento com margem posterior côncava sobre os gonocoxitos 8 . Laterotergitos 8 triangulares com cerca do dobro do comprimento dos laterotergitos 9 , bordo posterior com um pequeno espinho negro, mediano. Laterotergitos 9 com ápice arredondado e ultrapassando sutilmente a banda que une dorsalmente os laterotergitos 8 . Gonocoxitos 8 subquadrangulares, com cerca do dobro do comprimento longitudinal dos laterotergitos 9, margem posterior truncada, bordos suturais sub-retilíneos e delineados de negro, justapostos em quase toda a extensão (Fig. 87). Gonocoxitos 9 praticamente encobertos pelos gonocoxitos 8 . Décimo segmento quadrangular. Gonapófises 9 com espessamento da íntima vaginal campanulada e esclerotizado em anel incompleto. Chitinellipsen dispostas lateralmente ao espessamento da íntima vaginal. Ductus receptaculi na região anterior à área vesicular levemente mais longo que o comprimento do ductus na região posterior a mesma área. Cristas anulares anterior e posterior convergentes, pars intermedialis ovalada. Capsula seminalis ogival, com três dentes recurvos, digitiformes sendo dois longos ultrapassando a crista anular anterior em metade do seu comprimento e um levemente menor ultrapassando a crista anular anterior em $1 / 3$ do seu comprimento, todos surgindo da porção médio-basal (Fig. 86).

Distribuição. Brasil: Pará, Minas Gerais, Rio de Janeiro, São Paulo e Paraná.

Material examinado. Holótipo macho, com as etiquetas: a) Teresópolis, R. Jan., Brasil, II-1962; b) Col MRCN n²268; c) Serdia rotundicornis macho n. sp., M. Becker det. 1966. (MCNZ). Alótipo. BRASIL. Rio de Janeiro: Teresópolis, fêmea, II-1962, coll. MRCN n ${ }^{\circ}$ 2269. (MCNZ). Parátipo. BRASIL. Rio de Janeiro: Teresópolis, fêmea, II-1962, coll. MRCN, s/col. (MCNZ). BRASIL. Pará: Tiriós, Alto Parú do Oeste, fêmea, I-II-1963, Machado \& Pereira (MPEG); Minas Gerais: Serra da Mantiqueira, macho e 2 fêmeas, I-1961, leg. DZ104/61, Herbert (MNRJ); Rio de Janeiro: Teresópolis, fêmea, col. 1954, Zajciv leg., (MNRJ); São Paulo: Serra da Bocaina, S. José Barreira 1.650m, macho, I-1969, M. Alvarenga (AMNH); Eugênio Lefévre, Pindamonhangaba, macho, 23-XI-1962, Exp. Dep. Zool., (MZSP); Paranapiacaba, fêmea, 25-II-1962, L. Stowbunenko, (MZSP); Paraná: Curitiba, fêmea, II1968, Museu Paranaense n 29.510, R. Lange leg. (MNCE).

Comentários. O grupo $S$. rotundicornis ${ }^{+}$é sustentado por uma sinapomorfia, pars intermedialis de formato globoso, e dois caracteres homoplásticos, forma do corpo ovalada e folheto externo do bordo ventral do pigóforo, medianamente destituído de projeções. Porém, como diagnosticado por Becker (1967), distingue-se morfologicamente, das demais espécies 

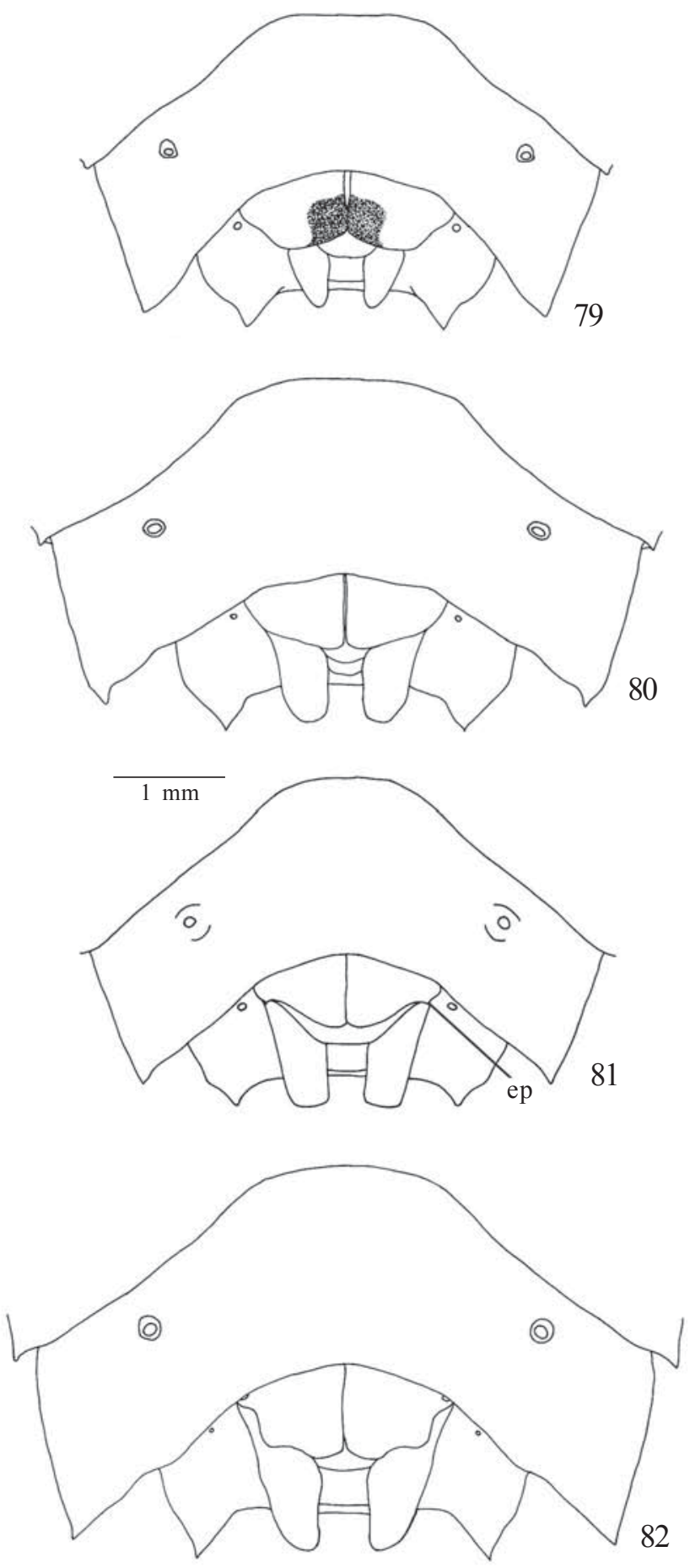

Figs. 79-82. Fêmeas: placas genitais, vista ventral. 79, Serdia lobata; 80, S. costalis.; 81, S. calligera; 82, S. maculata, sp. nov.; ep=espinho.

do gênero pelos ângulos umerais do pronoto de contorno arredondado e de orientação lateral, bem menos desenvolvidos que em S. apicicornis, bem como em S. maxima. Acrescentase, também, nos machos a forma do pigóforo com taça genital bastante escavada.
Serdia limbatipennis Stål, 1860

(Figs. 8, 25, 40, 55, 73, 87, 102, 110)

Serdia limbatipennis Stå1, 1860: 26 (descrição); Stå1 1872: 45 (redescrição, catálogo); Lethierry \& Severin, 1893: 179 (catálogo). Serdia (Serdia) limbatipennis; Kirkaldy, 1909: 141 (catálogo); Buckup, 1961: 12 (registro de ocorrência); Becker, 1967: 96 (redescrição, chave); Thomas \& Rolston, 1985: 1166 (chave).

Machos. Medidas (n=3). Comprimento total 11,3 (12,4-10,5) 0,4 ; largura abdominal $5,4(6,8-5,2) 0,1 ;$ comprimento da cabeça $1,9(2,1-1,8) 0,1$; largura da cabeça $2,4(2,6-2,3) 0,06$; comprimento dos artículos antenais I 5,4 (6,0-5,1) 0,06; II 0,5 (1,0-0,9) 0,06; III 1,3 (1,3-1,1) 0,1; IV 1,2 (1,3-1,0) 0,1; V 1,4; comprimento do pronoto $2,3(2,6-2,1) 0,06$; largura anterior do pronoto $2,6(2,8-2,5) 0,1$; largura posterior do pronoto $5,4(6,0$ $5,3) 0,1$; comprimento do escutelo $3,9(4,5-3,7) 0,1$; largura do escutelo 3,1(3,7-3,0)0,1.

Descrição. Forma ovalada, com margens abdominais quase paralelas, coloração castanho-clara a castanho-escura pontuações densas de coloração castanho-escuras. Cabeça com margem anteocular sinuosa, ápice levemente estreitado, margem externa das jugas moderadamente convergentes em direção ao ápice, podendo ser contíguas adiante do clípeo ou então deixando uma estreita fenda. Pontuações castanhas, menores junto as margens laterais das jugas e maiores no restante. Ocelos circundados na margem interna por uma pequena mancha castanho-escura e com inúmeras pontuações. Primeiro segmento amarelado e com pontuações negras bem como o $2^{\circ}$ e o $3^{\circ}, 4^{\circ}$ totalmente negro e dilatado (Fig. 102), $5^{\circ}$ amarelado. Rostro atingindo o terço posterior do mesosterno. Pronoto margens ântero-laterais suavemente curvas e crenuladas, ângulos umerais arredondados, não desenvolvidos. Superfície densamente pontuada, pontuações castanhas, menores ao longo da margem anterior, ântero-laterais e ao redor das cicatrizes. Cicatrizes concolores. Escutelo com margem apical não emarginada e 1+1 linhas negras nos bordos laterais (em alguns exemplares é muito sutil). Superfície homogeneamente pontuada, exceto no ápice onde as pontuações são menores e mais densas. Pequena área arredondada amarelada no centro da margem basal. Hemiélitro com pontuações castanhas, moderadamente densas e uniformes; no exocório são menores, mais densas na margem interna do terço posterior. Mancha discal concolor. Superfície torácica ventral de coloração mais clara, pontuações castanhoescuras maiores medianamente e mais esparsas. Uma faixa longitudinal larga situada medianamente nas pleuras com pontuações menores, densas e enegrecidas. Segmentos do conexivo amplamente expostos, âmbar, pontuações concolores em todos os segmentos, $7^{\circ}$ segmento com a diagonal posterior enegrecida e com pontuações castanhas. Ângulos pósterolaterais projetados em pequeno dentículo negro, mais visível no $7^{\circ}$ segmento. Superfície ventral do abdome de coloração castanho-escura a amarelada, moderadamente pontuada, pontuações castanhas. Espinho mediano do $3^{\circ}$ segmento abdominal agudo. Pernas amareladas com pontuações castanhas, esparsas sobre os fêmures e tíbias. 

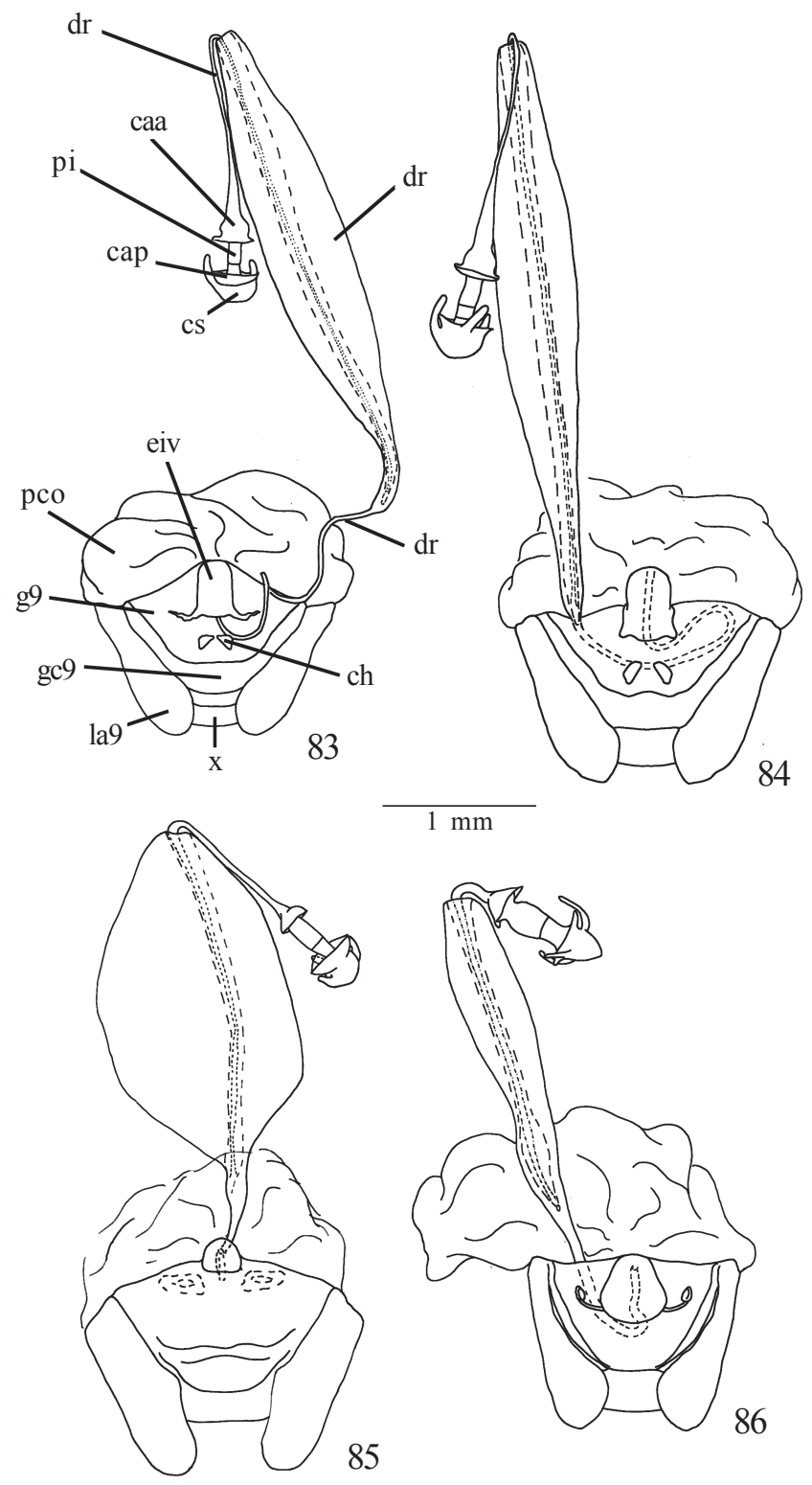

$1 \mathrm{~mm}$

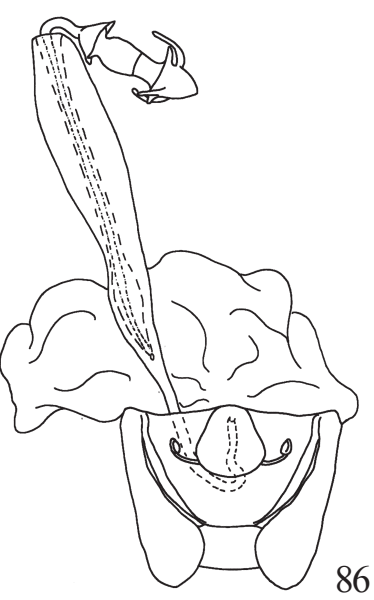

Figs. 83-86. Fêmeas: laterotergitos 9, gonocoxitos 9, gonapófises 9 e vias genitais ectodérmicas, vista ventral. 83, Serdia concolor; $84, S$. indistincta, sp. nov.; 85, S. beckerae; 86, S. rotundicornis; caa $=$ crista anular anterior, cap=crista anular posterior, $\mathrm{ch}=$ chitinellipsen, $\mathrm{cs}=$ capsula seminalis, $\mathrm{dr}=$ ductus receptaculi, eiv $=$ espessamento $\mathrm{da}$ íntima vaginal, g9=gonapófise $9, \mathrm{gc} 9=$ =gonocoxito 9 , la9=laterotergito 9, $\mathrm{pco}=$ pars comunis, $\mathrm{pi}=$ pars intermedialis, $\mathrm{X}=$ décimo segmento.

Genitália. Pigóforo de contorno quadrangular, globoso, taça genital parcialmente aberta, ventralmente com pontuações castanho-escuras uniformemente distribuídas no terço apical, nesta área de coloração castanho-clara a amarelada, restante castanho-escura. Ângulos póstero-laterais em "U" levemente aberto. Bordo dorsal fortemente sinuoso, delineado de negro de cada lado do $10^{\circ}$ segmento, medianamente com $1+1$ processos laminares convexos apicalmente situados próximo aos ângulos póstero-laterais e $1+1$ processos digitiformes situados lateralmente à base do $10^{\circ}$ segmento. Parede da taça genital desde os ângulos póstero-laterais até próximo aos processos digitiformes totalmente crenulada e escurecida, formando uma aba próximo aos ângulos póstero-laterais recoberta por um tufo de pêlos (Fig. 8). Bordo ventral em "V" aberto, medianamente com uma ruga suavemente delineada de negro apicalmente; bordo ventral fortemente projetado para o lado dorsal (fig 25). Décimo segmento subretangular situado perpendicularmente ao plano sagital (Fig. 8). Parâmeros subcilíndricos, projetados perpendicularmente ao plano sagital, deprimidos lateralmente, contorno dorsal com uma expansão lobada, rugosa e com um pequeno dente na base voltado para a expansão lobada e sustentando um tufo de pêlos (Fig. 40). Phallus. Vésica em tubo cilíndrico, com menos de 1/3 do comprimento da phallotheca; processo laminar, reduzido em gola que envolve a base do ductus seminis distalis, este muito curto. Gonoporo secundário em calha (Fig. 55).

Fêmea semelhante ao macho, exceto no comprimento do cório que atinge a margem posterior do $5^{\circ}$ segmento abdominal (Fig. 110). Medidas (n=5). Comprimento total 12,2 (12,8-11,8) 0,3 ; largura abdominal $6,3(6,4-6,2) 0,1$; comprimento da cabeça 2,2; largura da cabeça 2,7 ; comprimento dos artículos antenais I $0,6(0,7-0,6) 0,1 ;$ II $0,3(0,4-0,2)$ 0, 1; III 1,5 (1,6-1,4) 0, 1; IV 1,3 $(1,4-1,2) 0,1 ; \mathrm{V}$ falta; comprimento do pronoto $2,5(2,5-2,4) 0,1$; largura anterior do pronoto $2,9(3,0-2,9) 0,1$; largura posterior do pronoto $6,1(6,2-5,9) 0,1$; comprimento do escutelo $4,4(4,5-$ 4,4) 0,1 ; largura do escutelo $3,5(3,5-3,4) 0,1$.

Genitália. Superfície das placas genitais moderada e uniformemente pontuada. Sétimo segmento com margem posterior côncava sobre os gonocoxitos 8 . Laterotergitos 8 subtriangulares, subiguais em comprimento aos laterotergitos 9, bordo posterior sub-retilíneo com um pequeno espinho projetado medianamente, em alguns inconspícuo. Laterotergitos 9 subtriangulares, ápice arredondado e sutilmente ultrapassando a banda que une dorsalmente os laterotergitos 8 . Gonocoxitos 8 subquadrangulares de comprimento longitudinal subigual aos laterotergitos 9, moderadamente convexos com ápice direcionado posteriormente, bordos suturais subparalelos em quase toda a sua extensão, divergindo no terço posterior em forma de um pequeno "V" aberto, nesta região com uma faixa negra castanho-escura (Fig. 73). Décimo segmento quadrangular. Gonapófise 9 com espessamento da íntima vaginal parcialmente esclerotizado em anel. Chitinellipsen situadas lateralmente ao espessamento da íntima vaginal. Comprimento do ductus receptaculi na região anterior e posterior a área vesicular aproximadamente igual. Cristas anulares anterior e posterior convergentes, pars intermedialis ovalada. Capsula seminalis arredondada com três dentes recurvos, dois ultrapassando a crista anular anterior e um menor, todos surgindo da porção médio-basal (Fig. 87).

Distribuição. Brasil: Minas Gerais, Rio de Janeiro, Santa Catarina e Rio Grande do Sul.

Marterial examinado. Holótipo fêmea, com as etiquetas: a) Brasil; b) F.Sahlb; c) Type; d) Typus. (NHRS). Parátipos: BRASIL:Minas Gerais: 
Serra do Caraça, macho e fêmea, III-1963, F. Werner, U. Martins, L. Silva (MZSP); Santa Bárbara, Serra do Caraça, $1.450 \mathrm{~m}$, macho e fêmea, I-1970, F.M. Oliveira (AMNH); Santa Bárbara, Serra do Caraça, 1.450m, macho em fêmea, III-1971, F.M. Oliveira (AMNH); Santa Catarina: Mafra, fêmea, XII-1959, coll. MRCN n ${ }^{\circ} 3562$, s/ col., (MCNZ); Nova Teutônia, $27^{\circ} 11^{\prime} \mathrm{B} 52^{\circ} 23^{\prime} \mathrm{L}, 300-500 \mathrm{~m}$, macho, 18-X-1963, Fritz

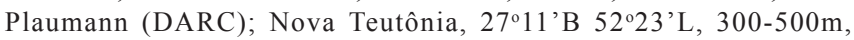
macho, XII-1973, Fritz Plaumann (DARC); Nova Teutônia, 27011'B 52 $23^{\prime}$ 'L, 300-500m, macho e fêmea, II-1974, Fritz Plaumann (DARC); Rio Grande do Sul: Torres, 2 fêmeas, 15-XI-1974, coll. MRCN n ${ }^{\text {os }}$ 8732 e 8734 , A. Lise leg. (MCNZ).

Comentários. O grupo S. limbatipennis ${ }^{+}$tem sua monofilia sustentada pela sinapomorfia, espinho do $3^{\circ}$ segmento abdominal em ângulo reto ou obtuso, além de duas homoplasias, terço mediano do bordo dorsal do pigóforo com processos e bordo ventral do pigóforo, medianamente, com estrias enegrecidas. S. limbatipennis diferencia-se das demais espécies do gênero, morfologicamente, pelo comprimento do cório que atinge a margem posterior do $5^{\circ}$ segmento abdominal, nas fêmeas e nos machos, pelo bordo dorsal do pigóforo fortemente sinuoso, com $1+1$ processos laterais laminares e $1+1$ processos digitiformes junto aos ângulos basais do $10^{\circ}$ segmento.

\section{Serdia bicolor, sp. nov.} (Figs. 74, 88)

Etimologia. Nome alusivo ao padrão de pontuações do pronoto.

Fêmeas. Medidas (n=2). Comprimento total 14,2 (14,4-13,9) 0,2 ; largura abdominal $6,8(6,8-6,7) 0,07$; comprimento da cabeça $2,1(2,1-2,0) \quad 0,07$; largura da cabeça $2,7(2,8-2,6) \quad 0,07$; comprimento dos artículos antenais I $0,7(0,7-0,6) 0,07$; II 0,3 $(0,4-0,3) 0,07$; III 1,9 (2,0-1,8) 0,2; IV 1,5 (1,5-1,4) 0,07; V 1,6 (1,7$1,5) 0,1$; comprimento do pronoto $2,9(3,0-2,8) 0,07$; largura anterior do pronoto $3,1(3,1-3,0) 0,07$; largura posterior do pronoto $6,7(6,8-6,5) 0,1$; comprimento do escutelo $5,2(5,3-5,2)$ 0,07, largura do escutelo $3,7(3,8-3,7) 0,07$.

Descrição. Forma ovalada, coloração castanha, pontuações castanho-escuras, moderadamente densas dorsalmente e menos densas e mais esparsas ventralmente. Cabeça com ápice estreito, margem anteocular levemente sinuosa, jugas justapostas apicalmente, superfície com pontuações castanhoescuras, uniformemente distribuídas exceto na base próximo aos olhos, ocelos circundados na margem interna por uma pequena mancha castanho-escura de forma semi-circular. Primeiro artículo antenal não ultrapassando o ápice da cabeça, de coloração castanho-escura com algumas manchas escuras irregulares na margem externa; $2^{\circ}, 3^{\circ}$ e $4^{\circ}$ negros, $3^{\circ}$ dilatado, deprimido lateralmente e com um sulco longitudinal; $5^{\circ}$ amarelado. Rostro ultrapassando o ápice da carena metasternal. Pronoto com ângulos umerais levemente arredondados e não desenvolvidos, margens ântero-laterais crenuladas e rasamente côncavas; pontuações mais densas numa faixa estreita acompanhando as margens ântero-laterais, nas margens internas e externas das cicatrizes e em 1+1 faixas longitudinais equidistantes do eixo longitudinal mediano que iniciam na margem posterior das cicatrizes e terminam na margem posterior do pronoto. Pontuações menores nas margens anterior e ântero-laterais. Cicatrizes castanho-claras a castanho-escuras, leve a moderadamente pontuadas; exceto no eixo longitudinal mediano onde não há pontuações. Escutelo com margem apical sutilmente emarginada e com 1+1 manchas pequenas nos bordos laterais. Pontuações de tamanho variável moderadamente densas e igualmente distribuídas. Hemiélitro com pontuações em série formando duas linhas externas à veia radial intercaladas por uma linha subcalosa destituída de pontuação, todas alcançando a sutura da membrana. Exocório com pontuações menores, margem externa imaculada, restante com pontuações moderadamente densas e uniformemente distribuídas. Célula discal ausente. Superfície torácica ventral de coloração castanho-claro com pontuações castanho-escuras densas na metade lateral externa de cada lado do tórax, no restante as pontuações são mais esparsas. Segmentos do conexivo expostos com superfície moderadamente pontuada, pontuações castanho-claras mais densas acompanhando a margem externa de cada segmento, último segmento com terço posterior enegrecido. Ângulos póstero-laterais arredondados e amarelados, exceto no último segmento que é pequeno, agudo e enegrecido; margem externa imaculada. Superfície ventral do abdome com pontuações moderadamente densas, castanho-avermelhadas. Espinho do terceiro segmento abdominal obtuso. Pernas de coloração castanho-claras, pontuações castanho-avermelhadas maiores e mais densas nos fêmures, levemente menores e mais esparsas nas tíbias, tarsos avermelhados.

Genitália. Superfície das placas genitais moderadamente pontuada, pontações uniformemente distribuídas sobre os laterotergitos 8, laterotergitos 9 e gonocoxitos 9; de tamanho variável e mais dispersas nos gonocoxitos 8 . Sétimo segmento com margem posterior angulada sobre os gonocoxitos 8 . Laterotergitos 8 subtriangulares, subiguais em comprimento aos laterotergitos 9, bordo posterior subretlíneo com um pequeno espinho mediano. Laterotergitos 9 com ápice arredondado e ultrapassando sutilmente a banda que une dorsalmente os laterotergitos 8. Gonocoxitos 8 arredondados, de comprimento longitudinal subigual aos laterotergitos 9 , fortemente convexos com ápice direcionado para o lado dorsal, bordos suturais paralelos em quase toda a sua extensão, divergindo no terço posterior em forma de "V"aberto; metade dos bordos suturais e toda a margem apical com uma faixa larga castanho-escura (Fig. 74). Gonocoxitos 9 com margem posterior avançando sobre a base do $10^{\circ}$ segmento, medianamente com um pequeno processo tuberculado bífido. Gonapófises 9 com espessamento da íntima vaginal esclerotizado em anel incompleto. Chitinellipsen situadas lateralmente ao espessamento da íntima vaginal. Comprimento do ductus receptaculi na região anterior a área vesicular aproximadamente igual a região posterior a mesma área. Cristas anulares anterior e posterior convergentes, pars intermedialis subcilíndrica, moderadamente alargada. Capsula seminalis esférica com três dentes recurvos de tamanho diferenciado, dois ultrapassando a crista anular anterior em mais da metade 


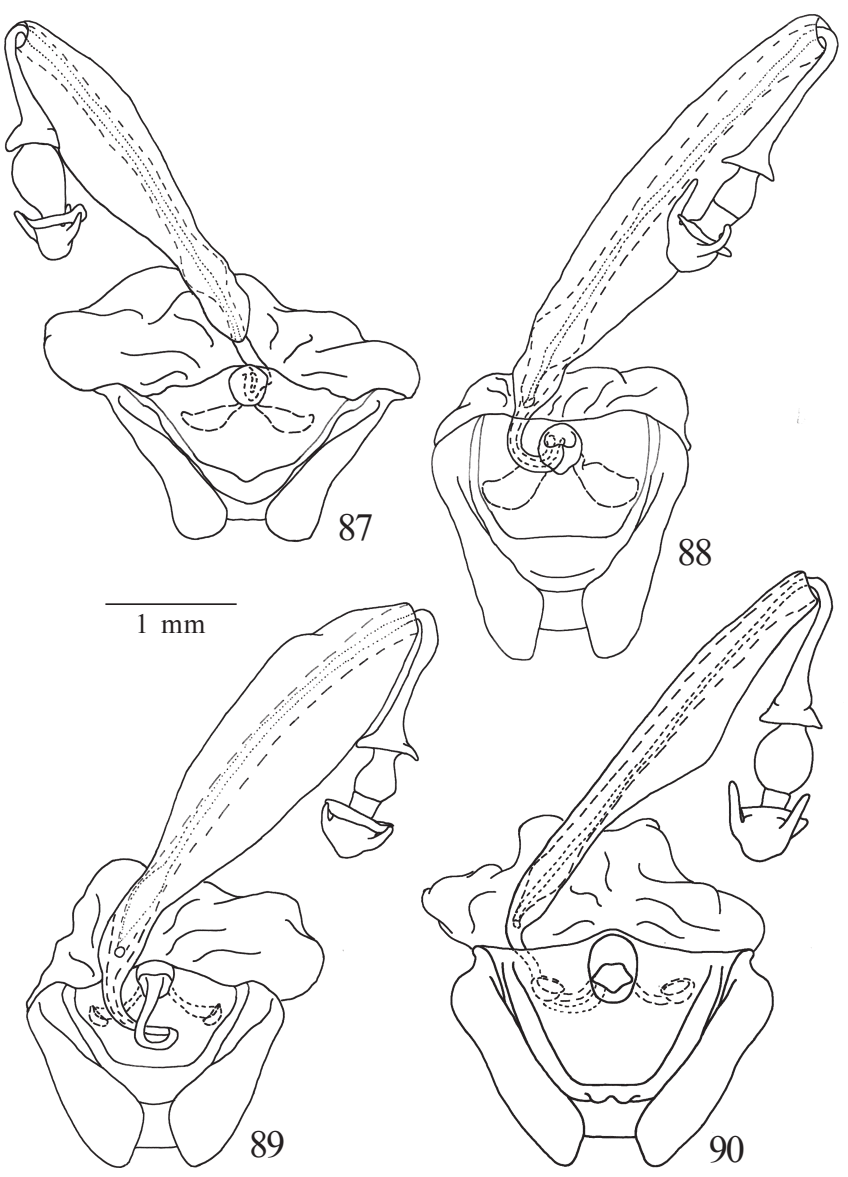

Figs. 87-90. Fêmeas: laterotergitos 9, gonocoxitos 9, gonapófises 9 e vias genitais ectodérmicas, vista ventral. 87, Serdia limbatipennis; 88, S. bicolor, sp. nov.; 89, S. inspersipes; 90, S. robusta, sp. nov.

do comprimento e um atingindo a metade do seu comprimento, todos surgindo na porção médio-basal (Fig. 88).

Distribuição. Brasil: Paraná e Santa Catarina.

Holótipo fêmea. BRASIL. Paraná: Ponta Grossa, G. chuva, I1957, n 6866 , V. Vilella (DZUP). Parátipo fêmea. BRASIL. Santa Catarina: Corupá, II-1952, A. Maller, col. Campos Seabra, (MNRJ).

Comentários. O parentesco entre as espécies do grupo $S$. bicolor $^{+}$é sustentado por uma reversão, $4^{\circ}$ artículo antenal cilíndrico e pelas margens ântero-laterais do pronoto crenuladas (homoplásico com S. quadridens). Distingue-se de todas as espécies do gênero, morfologicamente, por 1+1 faixas longitudinais de pontuações no pronoto, equidistantes do eixo longitudinal mediano que iniciam na margem posterior das cicatrizes e terminam na margem posterior do pronto.

Serdia inspersipes Stål, 1860

(Figs. 4, 21, 41, 60, 75, 89, 97, 117)

Serdia inspersipes Stål, 1860: 26 (descrição); Stål 1872: 45 (redescrição, catálogo); Lethierry \& Severin, 1893: 179 (catálogo).

Serdia (Serdia) inspersipes; Kirkaldy, 1909: 141 (catálogo); Becker,
1967: 94 (redescrição, chave); Thomas \& Rolston, 1985: 1166 (chave).

Macho. Medidas (n=6). Comprimento total 11,8 $(12,6-11,6)$ 0,1 ; largura abdominal $6,8(11,6-6,7) 0,2$; comprimento da cabeça 2,2 (2,2-2,0) 0,02; largura da cabeça 2,8 ; comprimento dos artículos antenais I $0,7(0,9-0,5) 0,1$; II 0,4 ; III $1,5(1,8-1,1) 0,3$; IV $1,6(2,2-1,3) 0,6 ; \mathrm{V} 1,7$; comprimento do pronoto $2,8(2,9-2,5)$ 0,1 ; largura anterior do pronoto $3,3(3,7-3,0) 0,2$; largura posterior do pronoto $6,3(6,8-6,0) 0,3$ comprimento do escutelo $5,0(5,4-4,9) 0,1$; largura do escutelo 4,5 (4,0-3,7) 0,2.

Descrição. Forma arredondada, coloração castanho-escura a castanho-clara, com pontuações castanho-avermelhadas densas e uniformemente distribuídas dorsalmente. Uma estreita linha vermelha acompanha as margens laterais do pronoto e conexivo dorsalmente e margens externas do abdome, ventralmente. Cabeça com ápice estreito, margem anteocular levemente sinuosa, jugas suavemente curvas e decliventes com as margens internas num plano bem mais baixo que as margens externas, ápice estreito e contíguo diante do clípeo, podendo deixar uma pequena fenda em "V"anteriormente (Fig. 97). Primeiro artículo antenal não ultrapassando o ápice da cabeça, de coloração castanho a amarelado com pontuações castanho-escuras grosseiras e esparsas, $2^{\circ}$ ao $4^{\circ}$ enegrecidos, $5^{\circ}$ amarelado. Rostro atingindo o terço anterior do metasterno. Pronoto com margens ântero-laterais crenuladas, sub-retilíneas e com uma linha vermelha submarginal acompanhando toda a margem dorsal e a margens laterais da pleura. Ângulos umerais levemente arredondados e não desenvolvidos. Superfície enrrugada, densamente pontuada, pontuações castanhoescuras. Cicatrizes concolores. Escutelo com margem basal eventualmente com uma pequeníssima mancha central amarelada, margem apical sutilmente emarginada e delicadamente delineada de negro nas laterais. Superfície enrrugada com pontuações densas e uniformemente distribuídas. Hemiélitro com margem externa do cório emarginada. Região basal da costa sub-retilínea e crenulada, semelhante as margens-ântero laterais do pronoto, margem costal estreitamente amarelada a castanho-clara. Exocório e região apical do cório até a altura em que este toca o escutelo, densamente pontuada mais fino que o mesocório e o clavo. Uma linha de pontos acompanha externamente a veia radial e outra acompanha o freno internamente. Célula discal amarelada, em alguns inconspícua. Superfície torácica ventral densamente pontuada, pontuações menores nas margens laterais e nas áreas evaporatórias meso e metapleurais, no restante as pontuações são maiores e mais grosseiras. Segmentos do conexivo exposto, superfície densamente pontuada, pontuações concolores na metade longitudinal externa dos segmentos $3^{\circ}$ a $6^{\circ}, 7^{\circ}$ com pontuações castanho-escuras tendendo a negra na margem apical. Uma linha avermelhada submarginal presente em todos os segmentos, contígua com a do pronoto. Ângulos póstero-laterais não apiculados do $3^{\circ}$ ao $6^{\circ}$ segmentos, $7^{\circ}$ apiculado e levemente escurecido. Superfície ventral do abdome densamente pontuada, pontuações castanhas Uma linha avermelhada acompanha toda 
a margem externa do abdome. Espinho do $3^{\circ}$ segmento abdominal obtuso. Pernas de coloração castanho-claras a castanho-escuras, pontuações castanho-escuras, grosseiras, levemente mais densas nos fêmures e mais esparsas nas tíbias.

Genitália. Pigóforo de contorno subquadrangular, com pontuações castanho-escuras sobre a taça genital. Ângulos póstero-laterais elevados, moderadamente arredondados. Bordo dorsal côncavo com $1+1$ processos apicais arredondados, junto aos ângulos póstero-laterais com ápices escurecidos e voltados para o interior da taça genital (Fig. 4). Bordo ventral profundamente escavado em "U" mediano, margem sinuosa até a metade da escavação, metade basal espessada, folheto interno recurvo com uma série de estrias negras medianamente (Fig. 21). Décimo segmento subquadrangular disposto perpendicularmente ao plano sagital, base ondulada e mais clara que o ápice (Fig. 4). Parâmeros digitiformes, situados paralelamente ao plano sagital, deprimidos lateralmente, com duas projeções convergentes no terço basal, sendo a mais apical rugosa na face externa e a mais basal com um tufo de pêlos na face interna (Fig. 41). Phallus: Vésica em tubo cilíndrico curto com 1/3 do comprimento da phallotheca e com 1 par de expansões laminares posteriores e um par de expansões laminares anteriores, menos volumosas, envolvendo $2 / 3$ do ductus seminis distalis. Gonoporo secundário arredondado (Fig. 60).

Fêmea semelhante ao macho. Medidas $(n=30)$. Comprimento total $13,3(14,1-11,5)$ (,3; largura abdominal 7,1 (7,5-6,3) 0,1 ; comprimento da cabeça $2,0(2,1-1,8) 0,07$; largura da cabeça $2,7(3,0-2,5) 0,08$; comprimento dos artículos antenais I $0,6(0,7-0,4) 0,09$; II $0,4(0,4-0,3) 0,06$; III $1,3(1,6-1,0) 0,1$; IV 1,3 $(1,6-1,1) 0,1$; V 1,6 (1,8-1,2) 0,2 ; comprimento do pronoto 2,8 $(3,0-2,5) 0,1$; largura anterior do pronoto $3,1(3,5-2,8) 0,08$; largura posterior do pronoto $6,3(6,7-5,8) 0,1$ comprimento do escutelo 5,0 (5,5-4,3) 0,1 ; largura do escutelo 3,8 $(4,2-3,5) 0,1$.

Genitália. Superfície das placas genitais densamente pontuada. Sétimo segmento com margem posterior côncava sobre os gonocoxitos 8. Laterotergitos 8 subtriangulares, subigual em comprimento em relação aos laterotergitos 9 , bordo posterior sub-retilíneo com um pequeno espinho mediano projetado posteriormente, uma faixa estreita avermelhada acompanha a margem apical do laterotergito, sendo que em alguns exemplares é inconspícua. Laterotergitos 9 subtriangulares, fortemente convergentes e encobrindo quase totalmente o $10^{\circ}$ segmento, ápice arredondado e sutilmente ultrapassando a banda que une dorsalmente os laterotergitos 8. Gonocoxitos 8 subquadrangulares com o dobro do comprimento dos laterotergitos 9, margem apical côncava, bordos suturais paralelos em toda a sua extensão (Fig. 75). Gonapófise 9 com espessamento da íntima vaginal parcialmente esclerotizado em anel incompleto sobre o orificium receptaculi. Chitinellipsen situadas lateralmente ao espessamento da íntima vaginal. Comprimento do ductus receptaculi na região anterior a área vesicular quase o dobro do comprimento do ductus na região posterior. Cristas anulares anterior e posterior convergentes, pars intermedialis ovalada. Capsula seminalis ovóide, com três dentes recurvos, digitiformes, dois ultrapassando a crista anular anterior, todos surgindo da porção médio-basal (Fig. 89).

Distribuição. Brasil: Minas Gerais, Rio de Janeiro, São Paulo, Paraná, Santa Catarina e Rio Grande do Sul.

Material examinado. Holótipo macho, com as etiquetas: a) Brazil; b) F. Sahlb; c) Type; d) Typus. (NHRS). Parátipo. BRASIL. Minas Gerais: Serra do Caraça, fêmea, 24-II a 03-III-1972, Exp. MZUSP (MZSP). BRASIL. Minas Gerais: Serra do Caraça, 4 fêmeas, s/ col. (UFRG); Rio de Janeiro: Itatiaia, 800m, fêmea, XII-1933, S. Lopes Est. Biológica (MNRJ); Itatiaia, 700m, Est. Biologica, fêmea, col. J.F.Zikán n ${ }^{\circ}$ 101/2734 (FIOC); Itatiaia, fêmea, 4-I-1950, W. Zikán (MNRJ); Itatiaia, L. $411.300 \mathrm{~m}$, fêmea, 10-12-X-1950, $\mathrm{n}^{\circ}$ 2735, Trav. Albuquerque \& Pearson (FIOC); Maromba (Itatiaia), fêmea, 29-XII1952, C. Leite, Seabra \& Zikán (MNRJ); Itatiaia, fêmea, 8-I-1964, col. J.F.Zikan ${ }^{\circ} 2732$ (FIOC); Petrópolis, Le Vallon Alt. Mosélla, fêmea, 24-I a 23-II-1956, D’Albuquerque leg. (MNRJ); Petrópolis, Le Vallon Alt. Mosélla, fêmea, s/ data, Spanhavery, (MNRJ); São Paulo: Boracea, fêmea, XII-1946, n 2736, Travassos (FIOC); Salesópolis, Est. Biol. Boracea, fêmea, 25-II-1963, F. Werner \& H. Reichardt leg. (MZSP); Salesópolis, Barueri, col. a luz, fêmea, 23-XII-1962, K. Lenko leg., (MZSP); Cantareira, macho, 1914, coll. MRCN no 3563, E. Garbe leg. (MCNZ); Osasco, fêmea, XII-1953, M.D’Andretta (MZSP); São Paulo, macho, s/ data, Mráz L.G.T., Museu Pragence (ZMBH); Paraná: Divisa Paraná com Santa Catarina, fêmea, XII-1974, Estrella leg. (DZUP); Santa Catarina: São Bento do Sul (Rio Vermelho), macho e 2 fêmeas, 21-II-1974, Mielke leg., (DZUP); São Bento do Sul (Rio Vermelho), 2 fêmeas, XII-1983, Exc. Dep. Zool., (DZUP); Rio, Vermelho, fêmea, I-1952, Dirings, coll. Dirings no 632, s/col. (MCNZ); Nova Teutônia, fêmea, 5-VII-1945, Fritz Plaumann (DARC); Rio Grande do Sul: Torres, macho e 5 fêmeas, 15-XI-1974, coll. MRCN $\mathrm{n}^{\text {os }}$ 8723, 8731, 8738, 8741, 8743, 8745, A. Lise leg.(MCNZ); São Francisco de Paula, Pró-Mata, macho, 21-XII-1997, C. Weirauch leg. (UFRG); Praia de Atlântida, Osório, fêmea, 10-I-1982, J. Grazia leg., (UFRG).

Comentários. Margem apical do escutelo refletida é uma sinapomorfia para o grupo $S$. inspersipes $+S$. robusta ${ }^{+}$. A relação de grupos irmãos entre $S$. inspersipes e $S$. robusta é estabelecida por duas reversões, corpo de formato arredondado e gonocoxitos 8 com o dobro do comprimento dos laterotergitos 9. Difere desta e de todas as espécies do gênero pelos ângulos umerais do pronoto arredondados, não pronunciados e pela presença de uma linha vermelha junto as margens ântero-laterais do pronoto, margens laterais do conexivo dorsalmente e margens laterais da pleura e do abdome ventralmente.

\section{Serdia robusta sp. nov.}

(Figs. 5, 22, 76, 90, 107, 113)

Etimologia. Nome alusivo ao tamanho do corpo e da genitália.

Macho. Medidas $(\mathrm{n}=1)$. Comprimento total 12,6; largura abdominal 6,5; comprimento da cabeça 2,1; largura da cabeça 2,1 ; comprimento dos artículos antenais I 0,5 ; II 0,4; III 1,6; IV1,5; V 1,8; comprimento do pronoto 2,8 ; largura anterior do pronoto 3,3 ; largura posterior do pronoto 6,3 ; comprimento do escutelo 4,7; largura do escutelo 3,7.

Forma arredondada, coloração castanho-claro a castanhoescuras, superfície densamente pontuadas dorsal (Fig. 13) e ventralmente. 


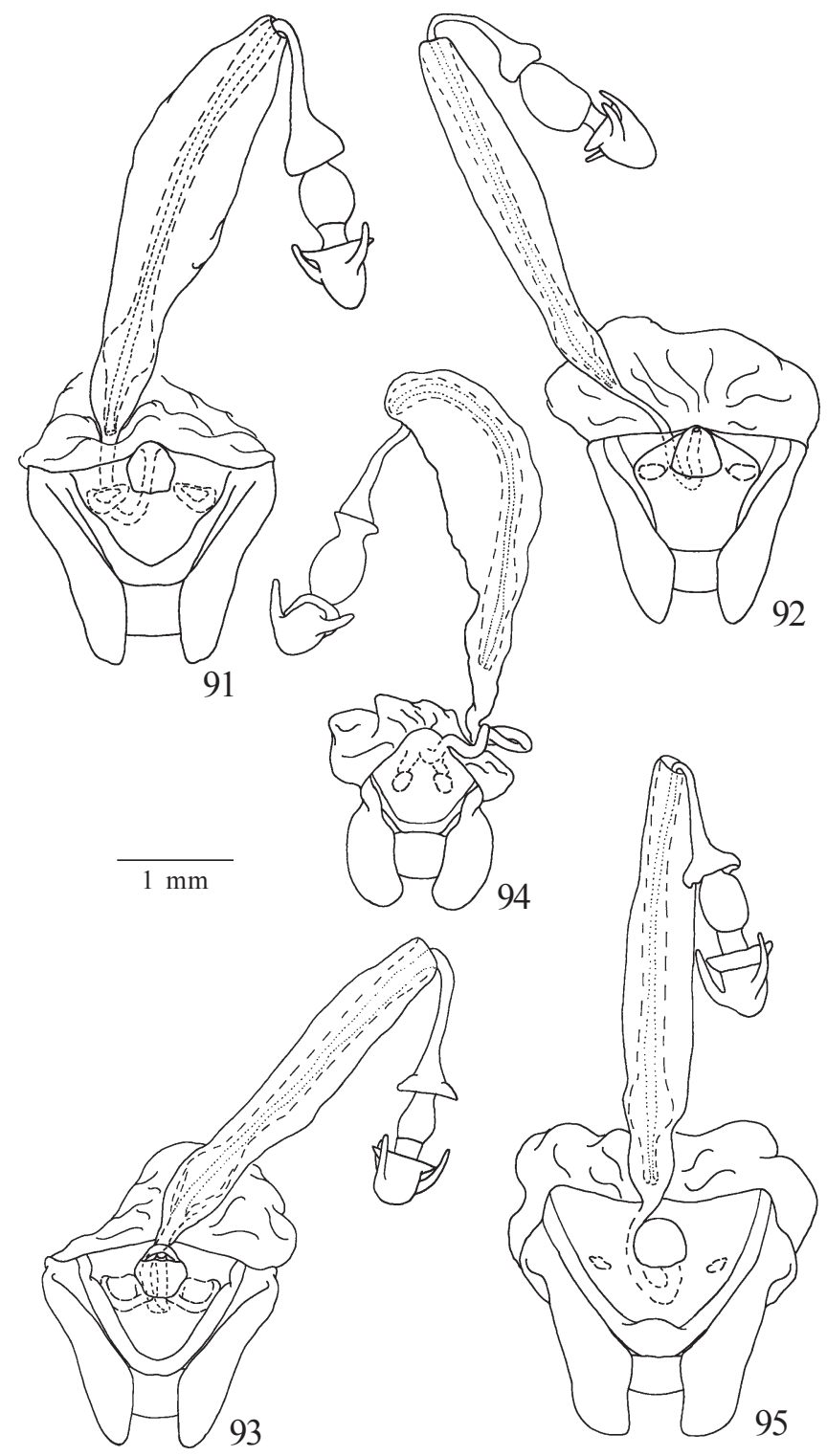

Figs. 91-95. Fêmeas: laterotergitos 9, gonocoxitos 9, gonapófises 9 e vias genitais ectodérmicas, vista ventral. 91, Serdia maxima sp. nov.; 92, S. apicicornis; 93, S. lobata; 94, S. maculata, sp. nov.; 95, S. calligera.

Descrição. Cabeça com ápice estreito, margem anteocular levemente sinuosa, jugas justapostas apicalmente, pontuações castanho-escuras uniformemente distribuídas exceto na base próxima aos olhos, ocelos circundados na margem interna por uma pequena mancha castanho-escura de forma semi-circular. Primeiro artículo antenal não ultrapassando o ápice da cabeça, coloração castanho-claro a amarelado com pontuações castanho-escuras grosseiras e esparsas, $2^{\circ}$ ao $4^{\circ}$ enegrecidos, e $5^{\circ}$ amarelado. Rostro não atingindo o ápice da carena metasternal. Pronoto com ângulos umerais levemente arredondados, não desenvolvidos, margens ântero-laterais crenuladas e rasamente côncavas (Fig. 107), superfície do pronoto enrrugada com pontuações uniformemente densas, exceto no contorno do pronoto onde são menores. Cicatrizes castanho-escuras. Escutelo com margem basal apresentando uma pequeníssima mancha central amarelada, margem apical sutilmente emarginada e delicadamente delineada de negro nas laterais. Superfície enrrugada com pontuações densas e uniformemente distribuídas. Hemiélitro com margem externa emarginada, pontuações moderadamente densas, menores acompanhando as margens externas até o limite da veia radial e próximos aos ângulos apicais, maiores no restante; uma linha de pontos acompanha externamente a veia radial e outra acompanha o freno internamente. Célula discal amarelada, em alguns inconspícua. Superfície torácica ventral densamente pontuada, pontuações menores no terço lateral externo da pro, meso e metapleura; no restante as pontuações são maiores e mais grosseiras. Segmentos do conexivo expostos, superfície densamente pontuada, pontuações concolores no $3^{\circ}$ segmento, castanho-escuras na metade interna dos segmentos $4^{\circ}$ a $6^{\circ}, 7^{\circ}$ segmento com pontuações castanho-escuras em quase todo o segmento, exceto na margem lateral externa. Ângulos póstero-laterais apiculados e enegrecidos principalmente no $6^{\circ}$ e $7^{\circ}$ segmentos. Superfície ventral do abdome densamente pontuada, pontuações castanho-claras. Espinho do $3^{\circ}$ segmento abdominal obtuso (Fig. 113). Pernas castanho-claras a castanho-escuras, pontuações castanho-escuras maiores e mais densas nos fêmures, levemente menores e mais esparsas nas tíbias, tarsos castanho-claros.

Genitália. Pigóforo em forma de sino, alargado posteriormente, taça genital amplamente aberta, ventralmente com pontuações castanho-escuras uniformemente distribuídas. Ângulos póstero-laterais abertos com ápice formando um "V" levemente aberto. Bordo dorsal sinuoso delineado de negro e com $2+2$ projeções medianas, uma lateral e uma basal. A projeção lateral é enegrecida, de formato subtriangular com ápice voltado para os parâmeros. A projeção basal é larga, subtriangular, disposta lateralmente ao $10^{\circ}$ segmento com superfície apical escurecida e voltada posteriormente. Entre as projeções basais o bordo dorsal é semi-ovalado. Parede da taça genital enegrecida e espessada, formando $1+1$ abas dispostas lateralmente a base do $10^{\circ}$ segmento (Fig. 5). Bordo ventral sinuoso, com um par de projeções medianas, elevadas posteriormente, face interna inteiramente estriada e escurecida (Fig. 22). Décimo segmento subquadrangular com base arredondada, ápice subquadrangular, escurecido, marginado com longos pêlos e disposto perpendicularmente ao plano sagital (Fig. 5). Parâmeros subcilíndricos, deprimidos lateralmente e de contorno escurecido, dispostos perpendicularmente ao plano sagital.

Fêmea semelhante ao macho. Medidas $(\mathrm{n}=7)$. comprimento total $16,6(16,9-15,4) 0,4$; largura abdominal $8,16(8,7-7,3) 0,3$; comprimento da cabeça 2,4 (2,5-2,3) 0,05; largura da cabeça 3,3 $(3,3-3,1) 0,04$; comprimento dos artículos antenais I $0,8(0,8-$ $0,7) 0,04$; II $0,4(0,6-0,4) 0,1$; III $1,9(1,9-1,8) 0,05$; IV 1,6 (1,8-1,5) 0,1 ; V falta; comprimento do pronoto $3,4(3,7-3,3) 0,09$; largura anterior do pronoto $3,7(3,8-3,7) 0,04$; largura posterior do 
pronoto $7,4(7,5-7,2) 0,09$; comprimento do escutelo $5,9(6,2-$ 5,5) 0,1; largura do escutelo 8,1 (8,7-7,3) 0,04 .

Genitália. Superfície das placas genitais densamente pontuada, pontuações ferrugíneas a castanho-claras uniformemente distribuídas. Sétimo segmento com margem posterior côncava sobre os gonocoxitos 8 . Laterotergitos 8 subtriangulares, subiguais em comprimento aos laterotergitos 9, bordo posterior sub-retilíneo com um pequeno espinho projetado medianamente. Laterotergitos 9 subtriangulares, ápice arredondado e ultrapassando sutilmente a banda que une dorsalmente os laterotergitos 8. Gonocoxitos 8 largos, subquadrangulares, com cerca do dobro do comprimento dos laterotergitos 9; fortemente convexos com ápice direcionado para a vista dorsal, bordos suturais paralelos em quase toda sua extensão, divergindo no terço posterior em forma de um pequeno "V" aberto. Metade interna dos gonocoxitos $8 \mathrm{com}$ uma grande mancha castanho-escura (Fig. 76). Gonapófises 9 com espessamento da íntima vaginal esclerotizado em anel incompleto. Chitinellipsen situadas lateralmente ao espessamento da íntima vaginal. Comprimento do ductus receptaculi na região anterior a área vesicular aproximadamente igual a região posterior a mesma área. Cristas anulares anterior e posterior convergentes, pars intermedialis globosa. Capsula seminalis globóide com três dentes recurvos de mesmo tamanho, um deles bifurcado apicalmente, todos surgindo na porção médio-basal e ultrapassando a crista anular anterior em metade do seu comprimento (Fig. 90).

Distribuição. Brasil: Rio de Janeiro, São Paulo, Santa Catarina e Rio Grande do Sul.

Holótipo macho. BRASIL. Rio de Janeiro: Itatiaia, 700m, 27-X1943, col. J.F. Zikan (FIOC). Parátipos: fêmea, BRASIL: São Paulo: Salesópolis, Est. Biol. Boracea, 12-II-1963, L. Silva \& H. Reichardt leg. (MZSP); 2 fêmeas, Santo Amaro, Faz. Curucucu, II-1950, H. Camargo (MACN); Santa Catarina: fêmea, Brusque, XII-1957, Coleção J. Lane (MZSP); Rio Grande do Sul: 3 fêmeas, Torres, 15-XI-1974, col MRCN nos $8729,8735,8736$, A. Lise leg. (MCNZ).

Comentários. S. robusta é grupo-irmão de S. inspersipes. Difere desta e de todas as espécies do gênero, morfologicamente, nos machos, pelo pigóforo em formato de sino e com taça genital amplamente aberta; nas fêmeas, pelo formato largo dos gonocoxitos 8 , com cerca do dobro do comprimento dos laterotergitos 9 e fortemente convexos.

Serdia apicicornis Stål, 1860

(Figs. 14, 31, 47, 62, 78, 92, 100, 108)

Serdia apicicornis Stål, 1860: 25 (descrição); Stål 1872: 45 (redescrição e catálogo); Lethierry \& Severin, 1893: 179 (catálogo).

Serdia (Serdia) apicicornis; Kirkaldy, 1909: 141 (catálogo); Becker, 1967: 85, (redescrição e chave) (partim); Thomas \& Rolston, 1985: 1166 (redescrição e chave).

Macho. Medidas ( $\mathrm{n}=8)$. Comprimento total 13,9 $(14,6-13,2)$ 0,3 ; largura abdominal 7,2 (7,6-6,9) 0,1 ; comprimento da cabeça $2,0(2,3-1,6) 0,1$; largura da cabeça $2,8(2,9-2,7) 0,05$; comprimento dos artículos antenais I $0,7(0,8-0,5) 0,1 ;$ II 0,5
$(0,6-0,4) 0,08$; III 1,9 (2,1-1,7) 0,$1 ;$ IV 1,7; V 1,6; comprimento do pronoto $3,2(3,4-3,0) 0,08$; largura anterior do pronoto $3,1(3,4-$ $2,9) 0,1$; largura posterior do pronoto $8,7(9,4-8,2) 0,3$; comprimento do escutelo $5,3(5,5-4,9) 0,1$; largura do escutelo 4,1 (4,2-3,9) 0,09.

Descrição. Forma ovalada, mais larga ao nível dos ângulos umerais, estes amplamente expandidos, obliquamente voltados para a frente, de ápice arredondado. Conexivo largamente serrilhado, com manchas negras nas suturas dos segmentos. Cor geral castanha com pontuações moderadamente densas, negras e diminutas especialmente ao longo da linha mediana dos ângulos umerais (Fig. 108). Cabeça mais larga que longa, margem anteocular sinuosa, jugas contíguas ou então deixando uma estreita fenda, 1/3 apical da margem interna deprimida dorso-ventralmente e num plano mais baixo que a margem interna. Disco da cabeça fracamente escavado e provido com inúmeras rugas finas e oblíquas. Pontuações castanhas, mais densas e uniformes sobre as jugas e mais esparsas sobre o clípeo, base da cabeça e superfície ao redor dos olhos, ocelos circundados na margem interna por uma pequena mancha castanho-escura e com inúmeras pontuações. Primeiro artículo antenal não ultrapassando o ápice da cabeça, recoberto por pontuações negras, $2^{\circ}$ ao $4^{\circ}$ negros bem como a base do $5^{\circ}$ artículo, porção restante amarelada. Rostro atingindo a extremidade posterior do metasterno. Pronoto quase três vezes a largura ao nível dos úmeros que longo medianamente, margens ântero-laterais crenuladas, emarginadas e com uma estreita linha calosa marginal. Superfície com uma faixa negra no terço mediano dos ângulos umerais que se prolonga longitudinalmente sobre o terço basal do pronoto ou restrita aos ângulos sob forma de uma grande mancha negra. Ângulos umerais muito desenvolvidos, de comprimento maior que a distância entre os olhos, elevados e voltados anteriormente, margem anterior das expansões umerais arredondada e estreitamente negra. Pontuações castanho-escuras, menores ao longo das margens laterais e posteriores e ao redor das cicatrizes, maiores no restante, mais concentradas nos ângulos umerais e na faixa longitudinal. Cicatrizes concolores. Escutelo pouco mais longo que largo na base, margem apical emarginada, recurvada e com $1+1$ pequenas manchas negras nos bordos laterais. Pontuações castanho-escuras, moderadamente densas, mais concentradas no centro do terço basal e laterais do terço mediano, no restante são levemente esparsas. Alguns exemplares com pontuações menores no disco do terço mediano. Pequena área amarelada arredondada no centro da margem basal. Hemiélitro com margens apicais refletidas e negras. Mesocório irregularmente pontuado, com duas fileiras longitudinais de pontuações diminutas e próximas entre si, paralelas a veia radial. Margem do exocório escurecida por uma banda de pontuações minúsculas e densas. Célula discal inconspícua. Superfície torácica ventral de coloração castanho-clara, propleura junto as expansões umerais intensa e delicadamente pontuada e de coloração levemente mais escura que o restante. Segmentos do conexivo largamente expostos, ângulos póstero-laterais salientes, projetados em pequeno espinho negro, manchas negras nas extremidades 

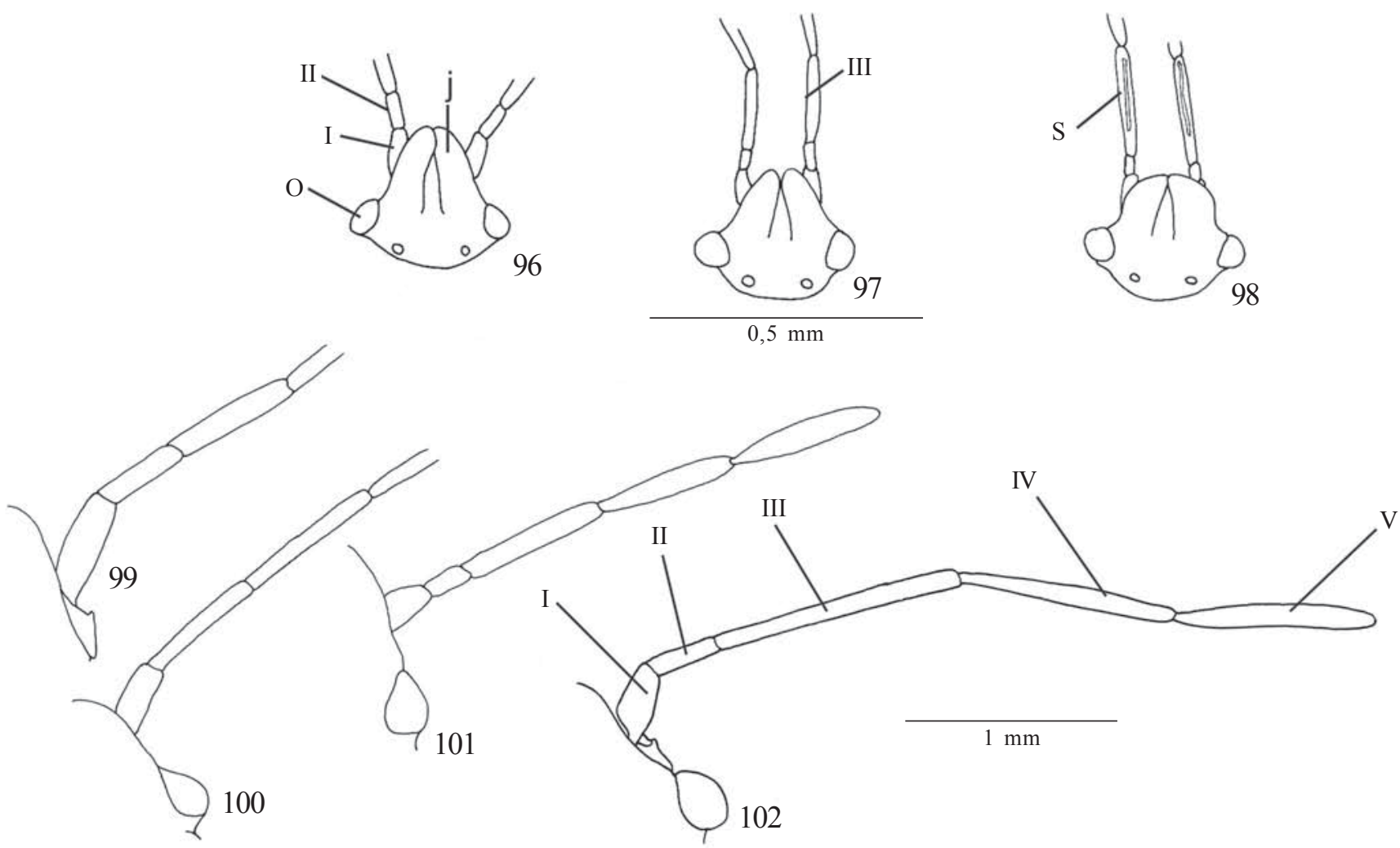

Figs. 96-102. Cabeça e artículos antenais, vista dorsal. 96, Serdia concolor; 97, S. inspersipes; 98, S. lobata; 99, Similliserdia aciculata; 100, Tibilis subconspersa; 101, S. maxima, sp. nov.; 102, S. limbatipennis; $\mathrm{j}=\mathrm{jugas,} \mathrm{o}=\mathrm{olho}, \mathrm{s}=$ sulco, I a $\mathrm{V}=$ artículos antenais.

anterior e posterior de cada segmento. Pontuações castanhoclaras a concolores, no $7^{\circ}$ segmento as manchas localizam-se no ângulo anterior externo e em toda a margem posterior do segmento. Tergito do $8^{\circ}$ segmento com $1+1$ manchas negras nos terços laterais da margem posterior. Superfície ventral do abdome de coloração castanho-escura a amarelada, densa e uniformemente pontuada, pontuações castanho-escuras. Presença de $1+1$ manchas negras medianas de formato subquadrangular no $6^{\circ}$ e $7^{\circ}$ esternitos. Espinho do $3^{\circ}$ segmento abdominal obtuso. Pernas com fêmures pintalgados por manchas castanho-escuras, que se repetem sobre a face sulcada das tíbias, tarsos avermelhados.

Genitália. Pigóforo globóide, bem mais escavado dorsal que ventralmente, ângulos póstero-laterais levemente côncavos e escurecidos apicalmente Parede da taça genital com $1+1$ banda escurecida. Bordo dorsal subquadrangular, levemente côncavo medianamente, limitado de cada lado da concavidade por um pequeno processo laminar, ápice enegrecido e voltado para a base dos parâmeros (Fig. 14). Bordo ventral em forma de "V" aberto, medianamente o folheto interno apresenta uma série de estrias negras (Fig. 31). Décimo segmento quadrangular disposto perpendicularmente ao plano sagital, marginado por uma faixa negra, exceto na base (Fig. 14). Parâmeros subcilíndricos, situados perpendicularmente ao plano sagital e com uma projeção basal digitiforme voltada para o bordo dorsal e outra projeção próxima ao ápice, deprimida lateralmente e com superfície apical rugosa dirigida posteriormente (Fig. 47). Phallus. Vésica em tubo cilíndrico curto com menos de 1/3 do comprimento da phallotheca com um par de projeções posteriores laminares, mais volumosas, deprimidas lateralmente, ápice recurvado e um par de projeções laminares mais volumosas deprimidas dorso-ventralmente envolvendo o ductus seminis distalis. Gonoporo secundário em calha (Fig. 62).

Fêmea semelhante ao macho exceto na ausência dos machas negras medianas na superfície ventral do $7^{\circ}$ segmento abdominal. Medidas $(\mathrm{n}=6)$. Comprimento total 14,9 $(16,8-13,9)$ 0,6 ; largura abdominal $7,7(8,1-7,6) 0,2$; comprimento da cabeça $2,3(2,4-2,2) 0,1$; largura da cabeça $2,7(2,9-2,7) 0,08$; comprimento dos artículos antenais I $0,6(0,7-0,5)$ 0,06; II 0,6 $(0,7-0,5) 0,08$; III 1,9 (2,1-1,6) 0,1; IV 1,7 (1,8-1,6) 0,1; V 1,7 (1,8$1,6) 0,1$; comprimento do pronoto $3,3(3,4-3,2) 0,06$; largura anterior do pronoto $3,1(3,4-3,0) 0,1$; largura posterior do pronoto $8,3(9,9-7,7) 0,8$; comprimento do escutelo $5,6(5,9-5,4)$ 0,1; largura do escutelo 4,1 (4,5-3,7) 0,2.

Genitália. Superfície moderadamente pontuada. Sétimo segmento com margem posterior angulada sobre os gonocoxitos 8 . Laterotergitos 8 triangulares, quase o dobro do comprimento dos laterotergitos 9, bordo posterior nitidamente ponteagudo posteriormente e com $1+1$ pequena mancha negra na altura média das margens externas, todas visíveis em vista dorsal. Laterotergitos 9 subtriangulares, ápice 
arredondado e ultrapassando nitidamente a banda que une dorsalmente os laterotergitos 8 . Gonocoxitos 8 trapezoidais, de comprimento subigual aos laterotergitos 9 , levemente entumescidos junto a margem posterior, esta rasamente côncava e delineada de negro principalmente no ápice dos bordos suturais, estes paralelos em quase toda a sua extensão, exceto no terço apical onde é suavemente digitiforme (Fig. 78). Décimo segmento quadrangular. Gonapófise $9 \mathrm{com}$ espessamento da íntima vaginal parcialmente esclerotizado em anel incompleto. Chitinellipsen situadas lateralmente ao espessamento da íntima vaginal. Comprimento do ductus receptaculi na região anterior a área vesicular levemente mais longo que o comprimento do ductus na região posterior. Cristas anulares anterior e posterior convergentes, pars intermedialis ovalada. Capsula seminalis ogival com três dentes recurvos, digitiformes, dois ultrapasando a crista anular anterior em $1 / 3$ do seu comprimento e o outro atingindo a crista, todos surgindo da porção médio-basal (Fig. 92).

Distribuição. Brasil: Rio de Janeiro, São Paulo, Paraná e Santa Catarina.

Material examinado. Holótipo: macho, examinado com as etiquetas: a) Brasil; b) F. Sahlb; c) Type; d) Typus. (NHRS). Parátipo: BRASIL: Rio de Janeiro: Itatiaia, 800ms., macho, XII-1933, S. Lopes E. T., R. Cunha (MNRJ). BRASIL. São Paulo: Avenida Paulista, macho, 13XII-1916, leg. Costa Lima, (MNRJ); Paraná: Quatro Barras, Banhado, macho e fêmea, 07-III-1970, Becker \& Laroca (DZUP); Quatro Barras, Banhado, fêmea, 09-III-1970, (DZUP); Antonina, Reserva Sapitanduva, lâmpada, macho, 01-I-1977, Lev. Ent. PROFAUPAR, (DZUP); São José dos Pinhais, Serra do Mar, Br. 277, Km 64, lâmpada, macho e 2 fêmeas, 02-I-1987, Lev. Ent. PROFAUPAR, (DZUP); Santa Catarina: São Bento do Sul (Rio Vermelho), 2 machos, 18-XII-1974, Mielke, (DZUP); São Bento do Sul (Rio Vermelho), macho e fêmea, XII-1983, Exc. Dep. Zool., (DZUP); São Bento do Sul (Rio Vermelho), fêmea, coll. Dirings n ${ }^{\circ} 229, \mathrm{~s} /$ data, s/ col., coll. MRCN n ${ }^{\circ} 3559$, (MCNZ); Rio Negrinho, macho, 24-I-1977, J. R. Robertson coll on loan. (LACM); Rio Negrinho, fêmea, 26-I-1977, J. R. Robertson coll on loan. (LACM).

Comentários. Junto com S. maxima sp. nov. formam um grupo monofilético sustentado por duas sinapomorfias, segmentos do conexivo com manchas escuras e manchas negras medianas no $7^{\circ}$ esternito dos machos, além da homoplasia, capsula seminalis de formato ogival. Diferem, morfologicamente, entre si pelo tamanho bastante reduzido dos parâmeros de S.apicicornis, cujo formato é subquadrangular e ausência de processos medianos no bordo dorsal do pigóforo. Nas fêmeas pelos bordos suturais dos gonocoxitos 8 tocando-se em toda a sua extensão e com uma faixa negra que avança sobre os gonocoxitos 8 .

Serdia maxima, sp. nov. (Figs. 13, 30, 46, 61, 77, 91, 101)

Serdia (Serdia) apicicornis; Becker, 1967: 93, fig. 9.

Etimologia. Nome alusivo ao tamanho dos ângulos umerais.

Macho. Medidas ( $\mathrm{n}=5)$. Comprimento total 14,0 $(14,8-13,3)$ 0,6 ; largura abdominal 6,8 (6,9-6,7) 0,1 ; comprimento da cabeça $2,2(2,4-2,0) 0,1$; largura da cabeça $2,7(2,9-2,5) 0,1$; comprimento dos artículos antenais I $0,7(0,7-0,6) 0,04$; II $0,5(0,5-0,4) 0,04$; III $1,8(1,9-1,7) 0,1$; IV $1,6(1,7-1,5) 0,1$; V $1,7(2,0-1,5) 0,4$; comprimento do pronoto $2,9(3,0-2,9) 0,1$; largura anterior do pronoto $2,7(2,9-2,5) 0,1$; largura posterior do pronoto $7,5(7,6-$ $7,4) 0,1$; comprimento do escutelo $5,2(5,4-5,0) 0,1$; largura do escutelo 4,1 (4,5-3,9) 0,2.

Descrição. Forma ovalada, ângulos umerais amplamente desenvolvidos, obliquamente dirigidos para frente, conexivo largamente exposto e com manchas negras nas suturas dos segmentos. Coloração castanho-clara a castanho-escura com pontuações castanho-escuras, moderadamente densas, podendo ser mais densas ventralmente. Cabeça com margem anteocular sinuosa, ápice estreito, jugas justapostas apicalmente, terço apical das jugas e clípeo sutilmente deprimidos dorso-ventralmente e num plano levemente mais baixo que o restante. Superfície com pontuações castanhas, mais densas e uniformes sobre as jugas e mais esparsas sobre o clípeo; base da cabeça e a superfície ao redor dos olhos destituídas de pontuação. Ocelos circundados na margem interna por uma pequena mancha castanho-escura. Primeiro artículo antenal com pontuações negras irregulares, não ultrapassando o ápice da cabeça, $2^{\circ}$ artículo de coloração negra assim como o $3^{\circ}, 4^{\circ}$ e a base do $5^{\circ}$, restante deste amarelado. Rostro ultrapassando o ápice da carena metasternal (fig 101). Pronoto quase três vezes a largura ao nível dos úmeros que longo medianamente, ângulos umerais fortemente desenvolvidos em projeções dirigidas ântero-lateralmente, com ápice arredondado, de comprimento maior que a distância entre os olhos. Margens ântero-laterais fortemente côncavas e crenuladas. Superfície com uma faixa negra no terço mediano dos ângulos umerais que se prolonga longitudinalmente sobre o terço basal do pronoto ou restrita ao ápice dos ângulos sob forma de uma pequena mancha; pontuações castanho-escuras, menores ao longo das margens laterais e posterior e ao redor das cicatrizes, maiores no restante e mais concentradas na metade basal. Cabeça e metade anterior do pronoto fortemente decliventes em relação ao restante do corpo. Cicatrizes concolores. Escutelo com margem apical emarginada, recurva e com $1+1$ pequenas manchas negras nos bordos laterais. Pontuações castanho-claras, maiores e mais densas no terço mediano e nas laterais do terço basal mediano, terço apical e disco do terço mediano menores e mais esparsas. Hemiélitro com pontuações em série formando duas linhas externas à veia radial intercaladas por uma linha subcalosa destituída de pontuação, todas quase atingindo a sutura da membrana. Pontuações moderadamente densas, menores no exocório e maiores no restante do cório. Célula discal ausente. Superfície torácica ventral de coloração castanho-clara a amarelada, pontuações castanho-claras a castanho-escuras, moderadamente densas, de tamanho variável e irregularmente distribuídas, sendo que alguns exemplares apresentam uma estreita banda de pontuações mais escuras extendendo-se longitudinalmente de cada lado e contíguas com o abdome. Propleura com uma pequena mancha no ápice dos ângulos umerais contígua com o lado dorsal. Segmentos do conexivo expostos, com superfície moderadamente pontuada, 

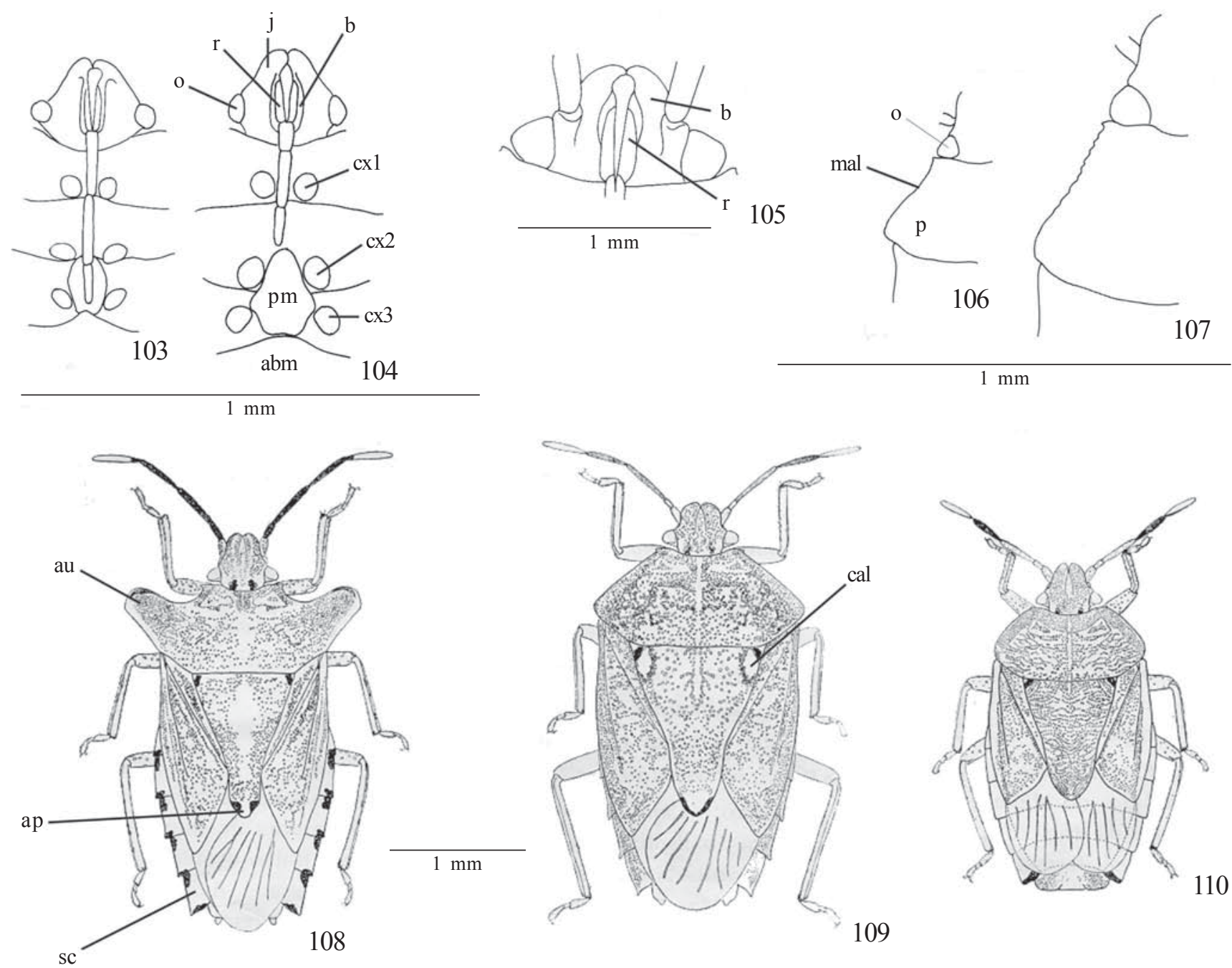

Figs. 103-110. 103-104, Cabeça e tórax, ventral de Serdia maxima, sp. nov. e S. concolor, respectivamente; 105, cabeça, ventralmente de Tibilis subconspersa; 106-107, margem ântero-lateral do pronoto de S. bihamulata e S. robusta, sp. nov., respectivamente; 108, S. apicicornis, sp. nov.; 109, S. calligera; 110, S. limbatipennis; abm=abdome, ae=ápice do escutelo, au=ângulos umerais, b=búcula, cal=calo, cx1,cx2,cx3=coxas 1 , 2 e 3 respectivamente, $\mathrm{j}=\mathrm{jugas}$, mal $=$ margem ântero-lateral, $\mathrm{o}=\mathrm{olho}, \mathrm{p}=$ pronoto, $\mathrm{pm}=$ placa metasternal, $\mathrm{r}=$ rostro, $\mathrm{sc}=$ segmento do conexivo). As figuras de $\mathrm{n}^{\mathrm{os}} 108$ a 110 foram retiradas de BECKER, 1967 (p. 91, figs 2, 3 e 5 .

pontuações castanho-claras uniformemente distribuídas, ângulos póstero-laterais, com manchas escuras nos ângulos laterais internos e externos, no $7^{\circ}$ segmento as manchas localizam-se no ângulo anterior externo e em toda a margem posterior do segmento. Superfície ventral do abdome de coloração castanho-escura a amarelada, moderadamente pontuada, pontuações castanho-escuras. Machos com 1+1 manchas negras medianas de formato subquadrangular no $7^{\circ}$ segmento. Espinho do $3^{\circ}$ segmento abdominal extendido anteriormente, obtuso. Pernas de coloração castanhoamareladas, pontuações castanho-escuras, moderadamente densas e grosseiras nos fêmures e tíbias, tarsos avermelhados.

Genitália. Pigóforo de contorno globóide, ventralmente com pontuações castanho-escuras de tamanho e distribuição variáveis. Ângulos póstero-laterais em "U" aberto, enegrecidos apicalmente. Parede da taça genital com $1+1$ abas negras internas dispostas lateralmente ao $10^{\circ}$ segmento. Bordo dorsal subquadrangular (Fig. 13). Bordo ventral em forma de "V" aberto, medianamente o folheto inferior apresenta estrias negras ventralmente maiores que em S.apicicornis (Fig. 30). Décimo segmento quadrangular situado perpendicularmente ao plano sagital, marginado por uma faixa larga negra exceto na base (Fig. 13). Parâmeros pequenos situados perpendicularmente ao plano sagital, de formato subquadrangular, com uma projeção basal em ângulo reto e um pequeno tufo de pêlos na margem externa, ápice com projeção digitiforme e voltada posteriormente (Fig. 46). Phallus. Vésica em tubo cilíndrico curto, cerca de 1/3 do comprimento da phallotheca. Processo da vésica lembrando um chapéu bávaro com um par de expansões laminares posteriores menos volumosas, deprimidos lateralmente, e um par de expansões laminares anteriores mais volumosas, também deprimidas 
lateralmente e envolvendo os $2 / 3$ basais do ductus seminis distalis. Gonoporo secundário em calha (Fig. 61).

Fêmea semelhante ao macho exceto nas manchas negras ventrais medianas do $7^{\circ}$ segmento abdominal que estão ausentes. Medidas ( $\mathrm{n}=13)$. Comprimento total 15,1 $(15,6-14,7)$ 0,2 ; largura abdominal 7,8 (8,0-7,3) 0,1 ; comprimento da cabeça $2,2(2,3-2,1) 0,05$; largura da cabeça $2,7(2,8-2,6) 0,05$; comprimento dos artículos antenais I $0,7(0,8-0,6) 0,06$; II 0,5 $(0,6-0,4) 0,07$; III 1,7 (1,9-1,4) 0,2; IV 1,6 (1,7-1,4) 0,1; V 1,7 (1,81,5) 0,1 ; comprimento do pronoto $3,3(3,3-3,1) 0,06$; largura anterior do pronoto $3,1(3,1-3,0) 0,04$; largura posterior do pronoto $8,1(8,5-7,9) 0,1$; comprimento do escutelo $5,5(5,7-5,3)$ 0,09 ; largura do escutelo 4,3 (4,7-4,2) 0,09.

Genitália. Superfície das placas genitais moderadamente pontuada. Sétimo segmento com margem posterior côncava sobre os gonocoxitos 8 . Laterotergitos 8 triangulares, quase o dobro do comprimento dos laterotergitos 9, bordos posteriores ponteagudos. Laterotergitos 9 subtriangulares, ápice arredondado e ultrapassando nitidamente a banda que une dorsalmente os laterotergitos 8 . Gonocoxitos 8 subtriangulares de comprimento longitudinal subigual aos laterotergitos 9, entumescidos com margem posterior arredondada e com uma estreita faixa negra que se continua nos bordos suturais; estes paralelos em toda a sua extensão (Fig. 77). Gonocoxitos $9 \mathrm{com}$ margem anterior pouco nítida, margem posterior convexa. Décimo segmento quadrangular. Gonapófise $9 \mathrm{com}$ espessamento da íntima vaginal parcialmente esclerotizado em anel incompleto. Chitinellipsen situadas lateralmente ao espessamento da íntima vaginal. Comprimento do ductus receptaculi na região anterior a área vesicular com cerca da metade do comprimento do ductus receptaculi na região posterior. Cristas anulares anterior e posterior convergentes, pars intermedialis ovalada. Capsula seminalis globóide, com três dentes recurvos surgindo da porção médio-basal e ultrapassando a crista anular anterior em $1 / 3$ do seu comprimento (Fig. 91).

Distribuição. Brasil: Espírito Santo, São Paulo, Paraná, Santa Catarina e Rio Grande do Sul; Paraguai: Ciudad de Leste; Argentina: Misiones.

Holótipo macho. BRASIL. Santa Catarina: Imbituba, II-1994, L.A. Campos (UFRG).Parátipos. BRASIL. Espirito Santo: Santa Teresa, fêmea, 13-I-1970, C.T. \& C. Elias leg. (DZUP); São Paulo: Piracicaba, macho, 13-X-1965; São Paulo, fêmea, 27-XII-1916, Leg. Costa Lima (MNRJ); Paraná: Rolândia, macho, s/ data, coll. MRCN no 3555 (MCNZ); Guaíra, fêmea, 14-XII-1965, V. Grat.-L. Azevedo (DZUP); Jaguariaiva, macho, 24-29-XII-1970, F. Giacomel leg., (DZUP); Foz do Iguaçu, noite-lamp. merc., 5 fêmeas, 17-XII-1966, D. Zoo. U.F.P. leg, (DZUP); Salto Osório, fêmea, 23-I-1974, J.Gr.-Vieira leg. (MCNZ); Santa Catarina: Imbituba, fêmea, II-1994, L.A. Campos (UFRG) Nova

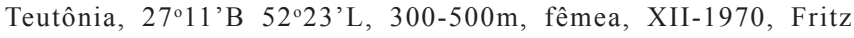
Plaumann (DARC); Rio Grande do Sul: Torres, macho, 15-XI-1974, coll. MRCN no 8716, A. Lise leg. (MCNZ); Torres, fêmea, coll. MRCN $\mathrm{n}^{\circ}$ 8717, A. Lise leg. (MCNZ); Osório, Capão Alto, fêmea, 13-II-1965, L. Buckup leg., (MCNZ); macho, s/ dados, no 507 (ZMHB); São Martinho, fêmea, 14-II-1979, Ferreira-M. (UFRG); PARAGUAI: Ciudad de Leste: macho, 19-XII-1971, Thomas F. Halsted coll. (DARC); ARGENTINA: Misiones: Puerto Iguazu, macho, 30-XII-1991, s/col., Thomas F. Halsted coll. (DARC).
Comentários. S. maxima sp. nov. é o grupo-irmão de $S$. apicicornis (ver comentários da espécie anterior). Porém separa-se desta, morfologicamente, nos machos, pela presença de processos medianos do bordo dorsal do pigóforo e parâmeros subcilíndricos; nas fêmeas, pelos gonocoxitos 8 com os bordos suturais tocando-se em apenas $2 / 3$ de sua extensão, terço apical suavemente digitiforme. A série examinada por Becker (1967) como S. apicicornis continha representantes das duas espécies. A ilustração da genitália masculina fornecida por Becker (1967: 93, Fig.9) trata-se, efetivamente, da de S. maxima sp. nov.

\section{Serdia lobata Thomas \& Rolston, 1985}

(Figs. 15, 32, 48, 63, 79, 93, 98)

Serdia (Serdia) lobata Thomas \& Rolston, 1985: 1165 (descrição, chave).

Macho. Medidas (n=4). Comprimento total 12,5 (13,4-12,3) 0,4 ; largura abdominal $3,2(3,2-3,1) 0,1 ;$ comprimento da cabeça $2,1(2,2-2,0) 0,1$; largura da cabeça $2,5(2,7-2,4) 0,1$; comprimento dos artículos antenais I $0,8(0,8-0,7) 0,1$; II 0,4 ; III 2,2 (2,4-2,0) 0,4 ; IV $1,6(1,7-1,5) 0,05 ; \mathrm{V} 1,7$; comprimento do pronoto 2,8 $(2,9-2,7) 0,1$; largura anterior do pronoto $2,7(2,8-2,6) 0,08$; largura posterior do pronoto $7,1(7,2-7,1) 0,1$; comprimento do escutelo 4,6 (4,7-4,5) 0,1; largura do escutelo 3,6 (4,0-3,5) 0,28.

Descrição. Forma ovalada com ângulos umerais produzidos e lobados ântero-lateralmente, superfície de coloração castanho-escura, e regularmente pontuada dorsalmente. Cabeça estreitada no ápice, margem anteocular levemente sinuosa, jugas não contíguas, terço apical fendido. Jugas com pontuações escuras, estas pontuações extendendo-se posteriormente até a base da cabeça como um par de faixas laterais até a metade de cada ocelo, estes com uma mancha escura na margem posterior. Primeiro artículo antenal escuro, $2^{\circ}$ ao $4^{\circ}$ castanho-escuros, $3^{\circ} \mathrm{com}$ um sulco mediano; $4^{\circ}$ dilatado (Fig. 98 ); $5^{\circ}$ amarelado. Rostro atingindo a metade ou mais do metasterno. Pronoto com úmeros fortemente enegrecidos e desenvolvidos em aba moderadamente estreita e dirigida ântero-lateralmente, comprimento maior que a distância entre os olhos. Margens ântero-laterais crenuladas, pontuações castanho-escuras densamente concentradas sobre os úmeros e margem lateral das cicatrizes; restante do pronoto com menos pontuações e irregularmente distribuídas. Cicatrizes castanhas. Escutelo com pontuações castanho-escuras de tamanho variável, em geral, menores em torno do disco e terço apical, maiores junto as margens laterais e no disco; superfície do escutelo de leve a moderadamente rugosa, margem apical delineada de negro nas laterais e com $1+1$ pequenas manchas castanho-escuras. Hemiélitro com exocório distintamente mais pálido que o disco do hemiélitro, entre o exocório e o hemiélitro há medianamente uma série de pontuações escuras, o restante com pontuações esparsas e irregularmente distribuídas. Mancha discal conspícua ou não. Superfície torácica ventral de coloração amarelo-clara com pontuações ferrugíneas moderadamente 

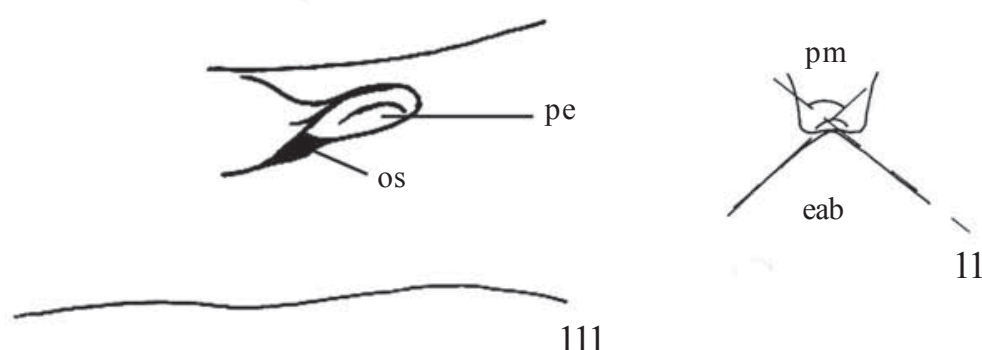

113

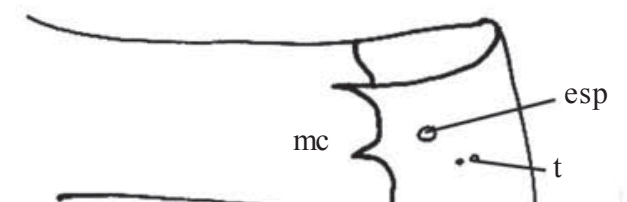

111
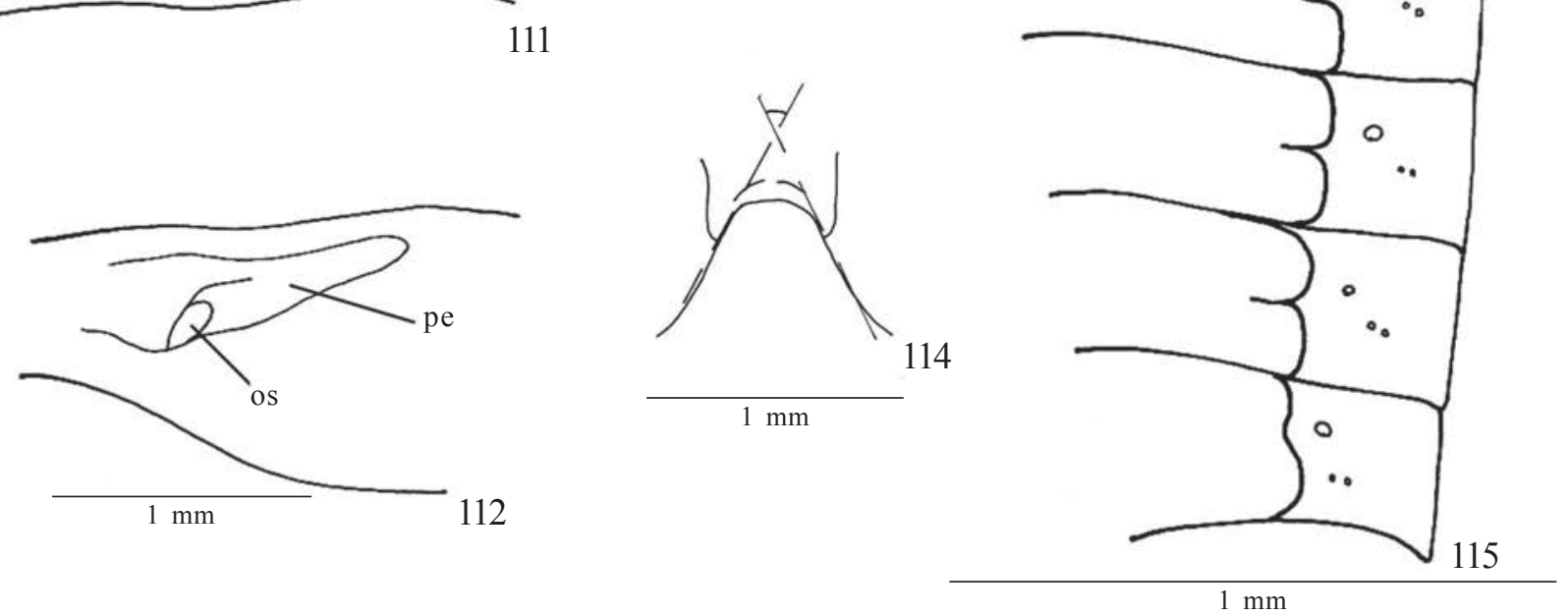

14

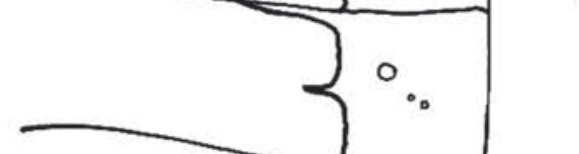

Figs. 111-115. 111-112, peritrema ostiolar de Serdia concolor e Tibilis subconspersa, respectivamente; 113-114, placa metasternal e espinho mediano do $3^{\circ}$ segmento abdominal de $S$. robusta, sp. nov. e $S$. maculata, sp. nov., respectivamente; 115, margem lateral do abdome de $S$. calligera, em vista ventral; eab=espinho abdominal, esp=espiráculo, $\mathrm{mc}=$ máculas, os $=$ ostíolo odorífero, $\mathrm{pe}=$ peritrema, $\mathrm{pm}=\mathrm{placa}$ metasternal, $\mathrm{t}=$ tricobótrios.

densas e irregularmente distribuídas. Segmentos do conexivo de coloração amarelo-escura, exposto; $7^{\circ}$ segmento castanhoescuro na área limitada pela margem lateral e posterior; ângulos póstero-laterais terminando em um espinho rombo do $3^{\circ}$ ao $5^{\circ}$ segmento; $6^{\circ}$ e $7^{\circ}$ terminando em espinho agudo.Superfície ventral do abdome com pontuações densas, ferrugíneas a concolores. Pernas de coloração castanho-clara a amarelada, com pequenas pontuações dispersas.

Genitália. Pigóforo de contorno quadrangular, moderadamente piloso, sem processos ventrais. Ângulos póstero-laterais em " $U$ " abertos. Parede da taça genital com1+1 abas enegrecidas dispostas lateralmente a base do $10^{\circ}$ segmento. Bordo dorsal côncavo (Fig. 15). Bordo ventral bissinuoso, recortado em "V" aberto, medianamente com uma projeção sinuosa, face interna inteiramente estriada e escurecida (Fig. 32). Décimo segmento quadrangular, disposto perpendicularmente ao plano sagital, escurecido e densamente piloso (Fig. 15). Parâmeros subcilíndricos, situados perpendicularmente ao plano sagital, levemente curvos na lateral externa e com um processo digitiforme, na sua base recobertos por alguns pêlos na face interna; ápice do parâmero obtuso, divergente ao processo digitiforme e enegrecido dorsalmente (Fig. 48). Phallus. Vésica semelhante à S. maxima sp. nov. porém com as expansões laminares posteriores bífidas. Gonoporo secundário em calha (Fig. 63).

Fêmea semelhante ao macho. Medidas ( $\mathrm{n}=8)$. Comprimento total $14,5(15,8-13,8) 0,5$; largura abdominal $7,1(7,4-6,7) 0,2$; comprimento da cabeça 2,0 (2,1-1,8) 0,09 ; largura da cabeça 2,7 $(3,0-2,5) 0,1$; comprimento dos artículos antenais I $0,7(0,8-0,6)$ 0,04 ; II 0,4 (0,5-0,4) 0,1; III 2, $1(2,4-2,0) 0,1$; IV 1,7 (1,8-1,6) 0,1; $\mathrm{V} 1,6$; comprimento do pronoto $3,0(3,2-2,9) 0,1$; largura anterior do pronoto $2,9(3,0-2,5) 0,1$; largura posterior do pronoto 7,8 $(8,1-7,4) 0,2$; comprimento do escutelo $5,2(5,5-4,9) 0,2$; largura do escutelo 3,9 (4,0-3,7) 0,1.

Genitália. Superfície das placas genitais moderadamente pontuada. Sétimo segmento com a margem posterior côncava sobre os gonocoxitos 8 . Laterotergitos 8 triangulares, com praticamente o dobro do comprimento dos laterotergitos 9 , bordo posterior nitidamente ponteagudo, ápice escurecido. Laterotergitos 9 subtriangulares, ápice arredondado e levemente mais estreito que a base, ultrapassando nitidamente a banda que une dorsalmente os laterotergitos 8 . Gonocoxitos 8 subtriangulares, de comprimento subigual aos laterotergitos 9, escurecido junto aos bordos suturais, estes paralelos em toda a sua extensão; margens posteriores dos gonocoxitos 8 em forma de "V" aberto (Fig. 79). Décimo segmento quadrangular. Gonapófise 9 com espessamento da íntima vaginal parcialmente esclerotizado em anel incompleto. Chitinellipsen dispostas lateralmente ao espessamento da íntima vaginal. Comprimento do ductus receptaculi nas regões anterior e posterior a área vesicular subiguais. Cristas anulares anterior e posterior convergentes, pars intermedialis estreita 


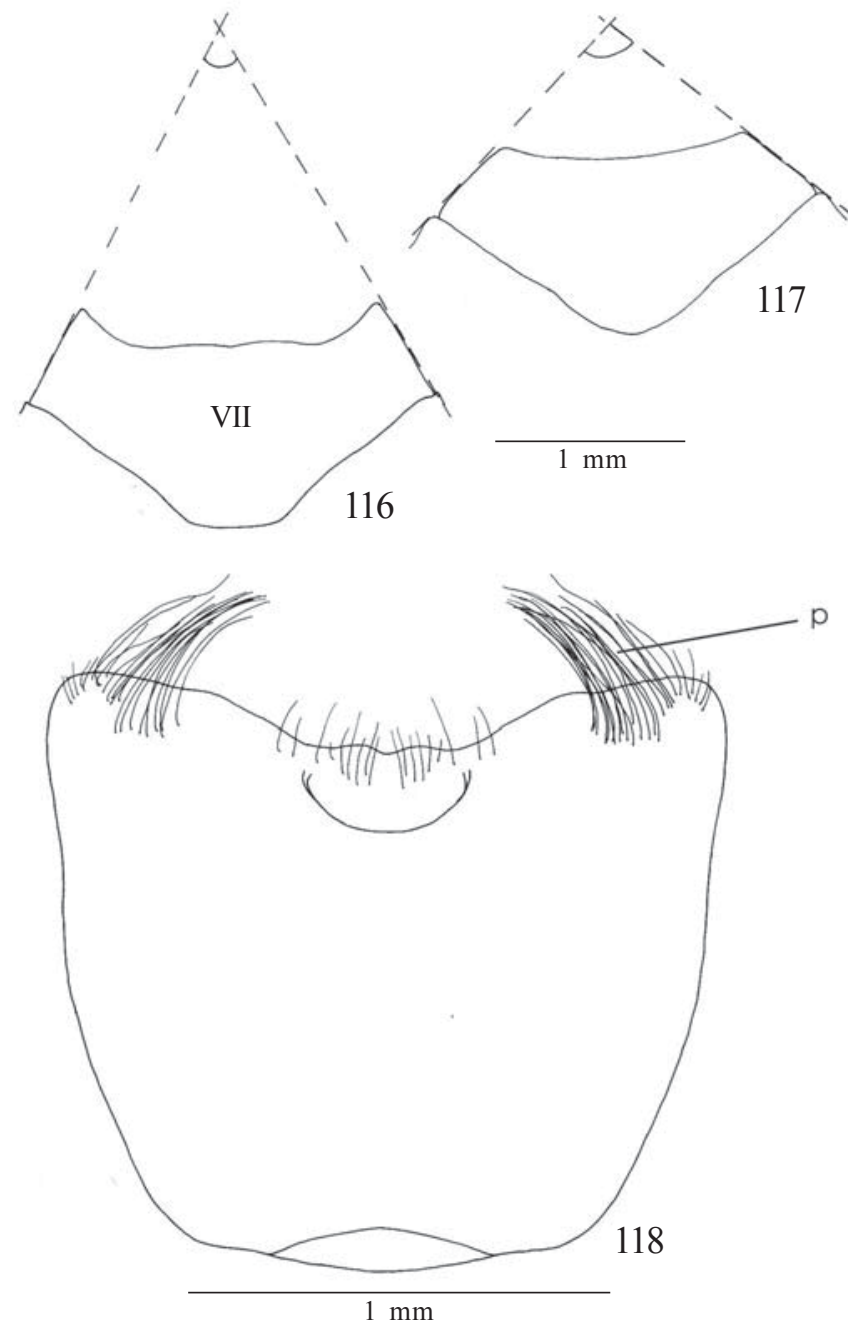

Figs. 116-118. 116-117, Sétimo segmento abdominal em vista ventral de Serdia beckerae e $S$. inspersipes, respectivamente; 118, pigóforo de $S$. ruckesi; $\mathrm{p}=$ pêlos, $\mathrm{VII}=7^{\circ}$ segmento abdominal.

na base e alargando-se medianamente. Capsula seminalis esférica com três dentes finos, recurvos, surgindo da porção basal e ultrapassando a crista anular anterior em mais de $1 / 3$ do seu comprimento (Fig. 93)

Distribuição. Brasil: Minas Gerais, São Paulo, Paraná e Santa Catarina.

Material examinado. Holótipo macho, com as etiquetas: a) Brasil, São Paulo: Serra Bocaína, S.J. Barreiro, 1.650m; b) Oct.-Nov. 1969 Alvarenga \& Seabra; c) Holotype Serdia lobata (AMNH). BRASIL. Minas Gerais: Serra da Mantiqueira, macho, II-1961, DZ 104/61 Herbert leg. (MNRJ); Serra do Caraça, fêmea, III-1963, F. Werner, U. Martins, L. Silva (MZSP); Serra do Caraça, fêmea, s/ data, s/ col. (MNRJ); São Paulo: Campos do Jordão, Eug. Lefevre, 1.200m, 2 fêmeas, 24-I1963, J. Guimarães, Medeiros, L. Silva, A. Rocha \& L.T.F. (MZSP); Paraná: Jaguariaiva, macho e 2 fêmeas, 28-XII-1966, F. Giacomel (DZUP); Santa Catarina: Corupá, fêmea, II-1956, A. Maller leg., (DZUP); São Bento do Sul (Rio Vermelho), macho e fêmea, IV-1973, F. Rank leg., (DZUP).
Comentários. O grupo irmão formado por S. lobata é sustentado por duas homoplasias: superfície dorsal do $3^{\circ}$ artículo antenal com sulco longitudinal e $4^{\circ}$ artículo antenal achatado. S. lobata diferencia-se de todas as espécies do gênero, morfologicamente, pelos segmentos do conexivo imaculados, inúmeras e pequenas pontuações nas pernas; nos machos, os parâmeros são muito maiores que em S. apicicornis, os quais podem ser vistos apenas removendo-se o $10^{\circ}$ segmento.

Serdia costalis Ruckes, 1958

(Figs. 16,33, 80)

Serdia costalis Ruckes, 1958b: 13 (descrição).

Serdia (Brasiliicola) costalis; Becker, 1967: 86 (redescrição, chave);

Thomas \& Rolston, 1985: 1166 (chave).

Macho. Medidas ( $\mathrm{n}=1)$. Comprimento total 11,1; largura abdominal 6,2; comprimento da cabeça 1,7; largura da cabeça 2,5; comprimento dos artículos antenais I 0,4; II 0,2; III 1,5; IV falta; $V$ falta; comprimento do pronoto 2,9 ; largura anterior do pronoto 2,7 ; largura posterior do pronoto 6,4 ; comprimento do escutelo 5,0; largura do escutelo 4,0.

Descrição. Forma ovalada, quase romboidal, coloração amarelo-escura com bandas submarginais no pronoto e com um par de manchas subtriangulares escurecidas no disco, além de uma mancha discoidal mediana e um par de manchas subapicais no escutelo, uma banda subcostal no hemiélitro entre o embólio e o cório, estes castanho-escuros. Pontuações ferrugíneas ou pálidas, moderadamente grosseiras, particularmente no disco do pronoto. Cabeça tão larga quanto longa, margem anteocular abruptamente sinuosa, larga e arredondada apicalmente, disco amarelo-escuro, pontuações ferrugíneas moderadamente densas e igualmente distribuídas; algumas raras rugosidades presentes. Ocelos com uma pequena mancha escura anterior. Primeiro artículo antenal atingindo o ápice da cabeça, de coloração marfim ou escuro, $2^{\circ}$ e $3^{\circ}$ escuros, $3^{\circ}$ com um sulco longitudinal; $4^{\circ}$ escuro e dilatado; $5^{\circ}$ totalmente amarelo-claro. Rostro atingindo o terço anterior da placa metasternal. Pronoto mais que duas vezes a largura ao nível dos úmeros que longo medianamente; centro do disco com algumas rugosidades, área mediana pálida, pontuações esparsas. Margens ântero-laterais sub-retilíneas, amarelo-escuras com pontuações concolores. Ângulos umerais não desenvolvidos. Cicatrizes concolores. Escutelo levemente mais longo que largo na base, fóveas negras com áreas calosas reiniformes; pontuações esparsas, tendendo a serem menores apicalmente até rarear. Margem apical emarginada e delicadamente delineada de negro nas laterais com $1+1$ pequenas manchas castanho-escuras. Hemiélitros com exocório inteiramente amarelo-escuro com pontuações igualmente finas e concolores, cório e clavo com pontuações mais grosseiras e escurecidas. Mancha discal ausente. Superfície torácica ventral de coloração amarelo-escuro, pontuações grosseiras e amplamente esparsas centralmente, mais finas e densas lateralmente. Espinho do $3^{\circ}$ segmento abdominal agudo. Segmentos do conexivo não visíveis, exceto 

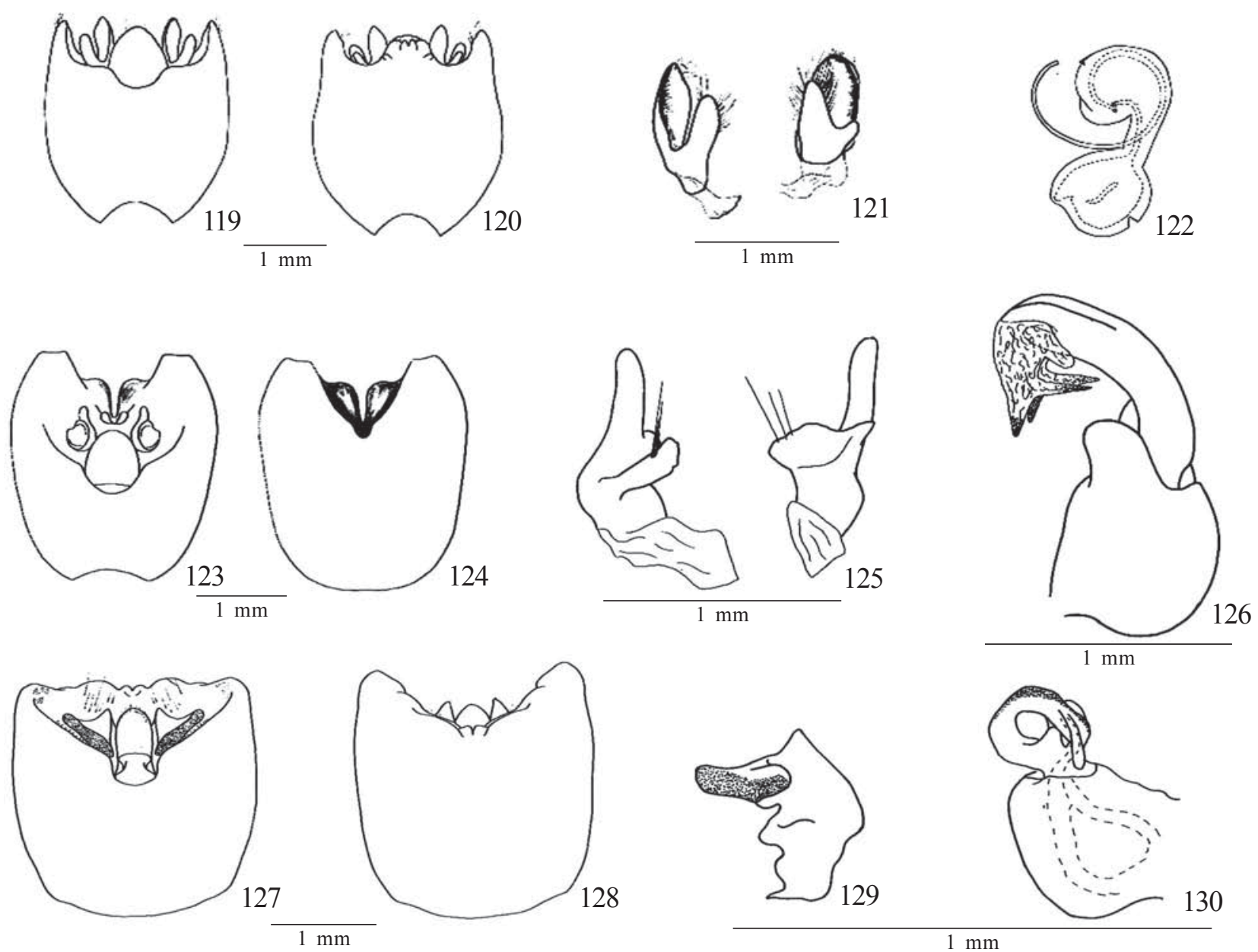

$1 \mathrm{~mm}$

Figs. 119-130. Genitália externa e interna dos machos dos grupos externos. 119-122 Tibilis: 119, pigóforo, vista dorsal; 120, pigóforo, vista ventral; 121, parâmero esquerdo, vista dorsal e lateral esquerda, respectivamente; 122, phallus, vista lateral. 123-126, Neotibilis: 123, pigóforo, vista dorsal; 124, pigóforo, vista ventral; 125, parâmero esquerdo, vista dorsal e lateral externa, respectivamente; 126, phallus, vista lateral. 127130, Similliserdia: 127, pigóforo, vista dorsal; 128, pigóforo, vista ventral; 129, parâmero esquerdo, vista lateral externa; 130, phallus, vista lateral.

no $7^{\circ}$ segmento, ângulos póstero-laterais agudos e diminutos. Superfície ventral do abdome com uma série contínua de máculas calosas, lisas e lúteas formando dois semicírculos por urosternito, voltados para os espiráculos. Pernas com fêmur e tíbia de coloração amarelo-escura, esparsamente pontuadas, pontuações ferrugíneas, tarsos avermelhados.

Genitália. Pigóforo arredondado, densamente piloso na parede externa e interna da taça genital. Ângulos pósterolaterais em "U" estreito. Bordo dorsal com $2+2$ processos medianos, um de formato digitiforme, próximo aos ângulos basais, com metade apical escurecida, voltada para os parâmeros e outro quadrangular, enegrecido apicalmente e menos desenvolvido que o anterior. Medianamente o bordo dorsal é côncavo (Fig. 16). Bordo ventral côncavo, enegrecido e medianamente com estrias enegrecidas (Fig. 33). Décimo segmento arredondado, disposto perpendicularmente ao plano sagital e dividido em duas porções; a porção basal mais estreita e amarelo-clara, com raros pêlos; porção apical mais larga, negra e bastante pilosa (Fig. 16). Parâmeros subcilíndricos, dispostos paralelamente ao plano sagital, margem lateral externa sinuosa e escurecida voltada para os processos digitiformes do bordo dorsal.

Fêmea semelhante ao macho. Medidas ( $\mathrm{n}=1$ ). Comprimento total 14,1; largura abdominal 7,6; comprimento da cabeça 2,0; largura da cabeça 3,2; comprimento dos artículos antenais I 0,5 ; II 0,2 ; III 1,6; IV 1,5; V 1,6; comprimento do pronoto 3,5; largura anterior do pronoto 3,4 ; largura posterior do pronoto 7,9; comprimento do escutelo 6,0; largura do escutelo 5,0.

Genitália. Superfície com raras pontuações inconspícuas. Sétimo segmento com margem posterior côncava sobre os gonocoxitos 8. Laterotergitos 8 triangulares, com quase o dobro do comprimento dos laterotergitos 9 , bordo posterior nitidamente ponteagudo, ápice escurecido. Laterotergitos 9 com ápice truncado e ultrapassando nitidamente a banda que une dorsalmente os laterotergitos 8 . Gonocoxitos 8 subquadrangulares, de comprimento longitudinal subigual aos 

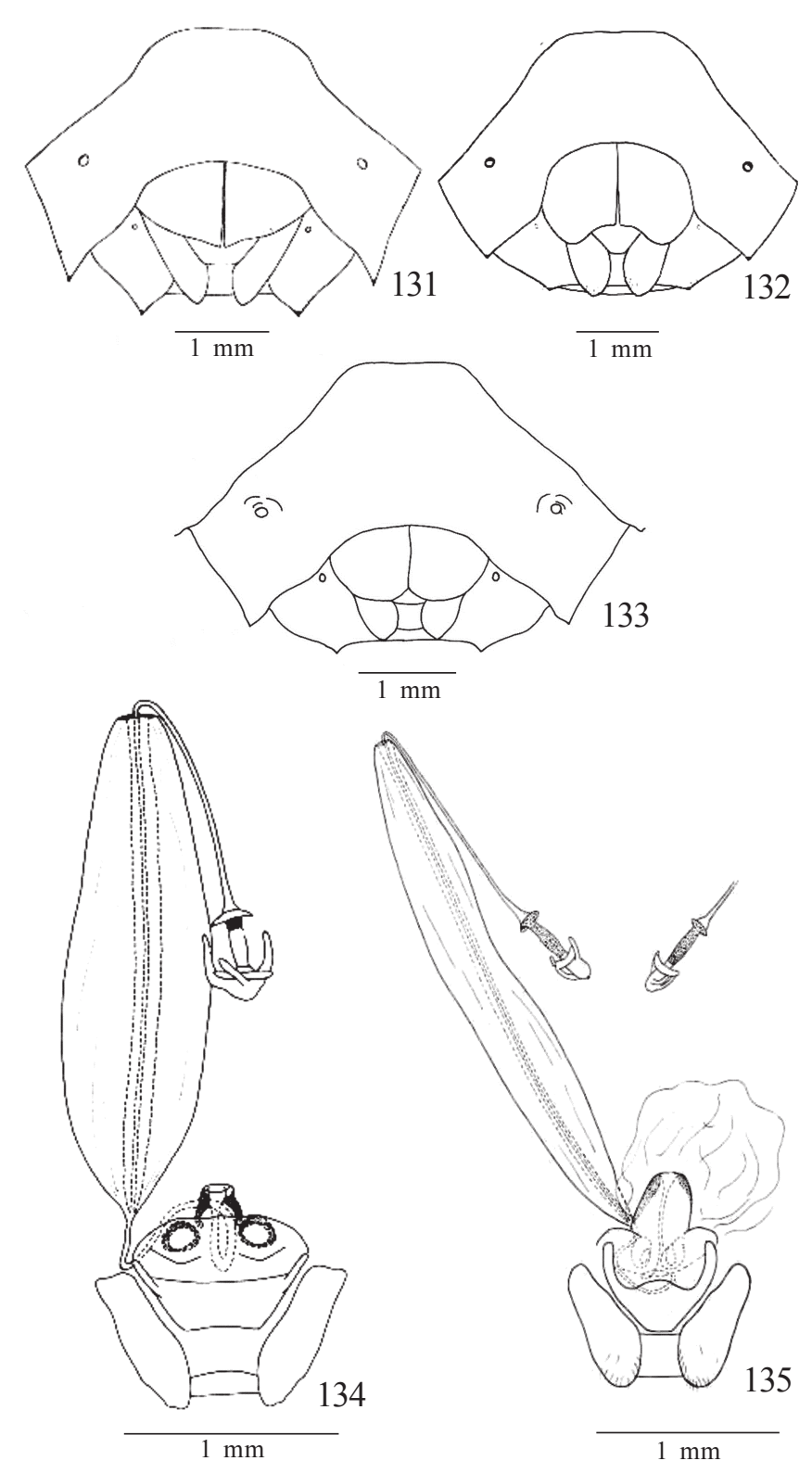

Figs. 131-135. 131-133, placas genitais das fêmeas em vista ventral: 131, Tibilis; 132, Neotibilis; 133, Similliserdia; 134-135, laterotergitos 9, gonocoxitos 9, gonapófise 9 e vias genitais ectodérmicas das fêmeas em vista ventral de Tibilis e Neotibilis, respectivamente.

laterotergitos 9, ápice arredondado, bordos suturais paralelos em toda a sua extensão. Gonocoxitos 9 arredondados. Décimo segmento quadrangular (Fig. 80).

Distribuição. Brasil, Bahia.

Material examinado. Holótipo fêmea, com as etiquetas: a) Bahia; b) Serdia costalis Ruckes, Holotype (AMNH). BRASIL. Bahia: fêmea, s/ data; s/ col. (ZMHB).

Comentários. S. costalis $^{+}$é sustentado por três sinapomorfias: cabeça de contorno quadrangular diante dos olhos, máculas calosas ventrais no abdome e parâmeros largos, deprimidos lateralmente com projeção perpendicular ao ápice do parâmero; uma homoplasia, escutelo com calos posteriores a fóvea e cinco reversões, terço apical das jugas sobrepostas diante do clípeo, margens ântero-laterais lisas, ângulos umerais não desenvolvidos, espinho mediano do $3^{\circ}$ segmento abdominal em ângulo agudo corroboram a monofilia do clado. Diferencia-se de todas as espécies do gênero, morfologicamente, pelo padrão de manchas amarelo-escuras dorsais do pronoto, escutelo e hemiélitros em forma de bandas submarginais, nas margens laterais do pronoto, subtriangulares no disco deste, uma mancha discoidal romboidal mediana no escutelo e uma banda subcostal no hemiélitro, entre o embólio e o cório.

Serdia calligera Stål, 1860

(Figs. 17, 34, 49, 64, 81, 95, 109, 115)

Serdia calligera Stål, 1860: 26 (descrição); Stål, 1872: 46 (redescrição e catálogo); Lethierry \& Severin, 1893: 179 (catálogo).

Serdia (Brasiliicola) calligera; Kirkaldy, 1909: 141 (catálogo); Ruckes, 1958b: 15 (diagnose); Buckup, 1961: 12 (registro de ocorrência); Becker, 1967: 85 (redescrição, chave); Link \& Grazia, 1983: 124; Link \& Grazia, 1987: 121; Thomas \& Rolston, 1985: 1166 (chave).

Macho. Medidas (n=24). Comprimento total 13,2 $(13,8-12,3)$ 0,$2 ;$ largura abdominal $7,7(8,4-7,2) 0,2 ;$ comprimento da cabeça $1,9(2,2-1,7) 0,1 ;$ largura da cabeça $2,8(3,0-2,5) 0,1$; comprimento dos articulos antenais I $0,6(0,7-0,4) 0,1 ;$ II $0,3(0,4-0,2) 0,1 ;$ III $1,8(2,0-1,6) 0,1 ;$ IV $1,5(1,6-1,4) 0,1 ;$ V $1,7(1,8-1,6) 0,1$; comprimento do pronoto $3,4(3,5-3,2) 0,1$; largura anterior do pronoto $3,1(3,4-2,9) 0,1$; largura posterior do pronoto $7,5(7,9-$ $7,1) 0,1$; comprimento do escutelo $5,7(6,0-5,4) 0,1$; largura do escutelo 4,5 (4,7-4,2) 0,1.

Descrição. Forma arredondada de coloração castanho-clara a castanho-escura com banda submarginal no pronoto e com 1+1 calo alaranjado nos ângulos basais do escutelo. Pontuações castanho a castanho-escuras irregularmente distribuídas. Ventralmente o abdome é proeminentemente caloso lateralmente (Fig. 109). Cabeça tão larga quanto longa medianamente, margem anteocular abruptamente sinuosa, carenada, larga e arredondada apicalmente, jugas mais longas que o clípeo e estreitamente contíguas apicalmente. Base das jugas com inúmeras rugas finas e oblíquas. Pontuações castanho-escuras moderadamente densas e igualmente distribuídas. Ocelos com uma pequena mancha negra atrás de cada ocelo recoberto por pontuações, olhos bastante salientes. Primeiro artículo antenal atingindo a ultrapassando o ápice da cabeça, $1^{\circ}$ ao $4^{\circ}$ escuros, $3^{\circ}$ deprimido com sulco longitudinal, $5^{\circ}$ totalmente amarelado. Rostro atingindo o metasterno. Pronoto mais que duas vezes a largura ao nível dos úmeros que longo medianamente. Ângulos umerais sub-retilíneos e não desenvolvidos. Margens ântero-laterais sub-retilíneas. Pontuações castanho-escuras fortemente densas, em alguns, com faixa submarginal acompanhando as margens ânterolaterais e de tamanho diferenciado, sendo menores em torno das cicatrizes, estas castanhas a concolores. Superfície com 


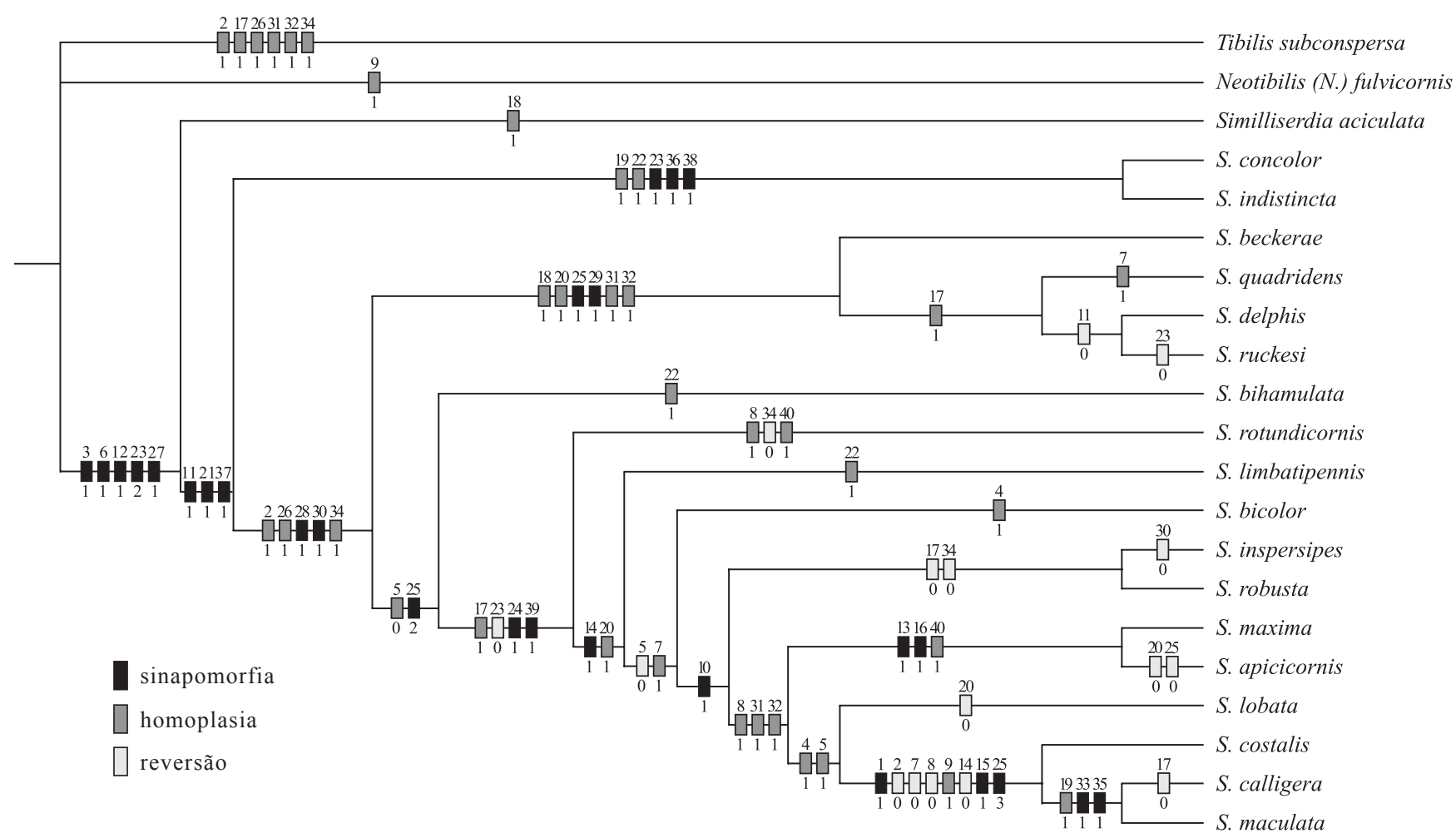

Fig 136. Cladograma.mostrando as relações filogenéticas das espécies de Serdia e a distribuição dos caracteres. O cladograma apresentou 83 passos, índice de consistência de 0,51 e índice de retenção de 0,75.

muitas rugas transversais. Escutelo mais longo que largo na base. Fóveas com 1+1 calos grandes, alaranjados circundados por pontuações castanho-escuras, menos densas que o pronoto e dimunuindo gradativamente em direção ao ápice, este com margem apical com 1+1 pequenas manchas castanhoescuras nas laterais. Hemiélitro com superfície castanho-clara a castanho-escura, pontuações castanhas, exocório finamente pontuado, mesocório e clavo com pontuações maiores e menos densas. Mancha discal ausente. Superfície torácia ventral de coloração amarelada a castanho-escura na faixa mediana das pleuras, no restante castanho-escura a enegrecida e esta separação de coloração é marcada por uma linha castanhoescura contígua com as máculas calosas abdominais. Pontuações castanho-escuras menores e mais densas na faixa longitudinal castanho-clara e maiores e irregulares na faixa amarelada. Segmentos do conexivo expostos, de coloração castanha, delicadamente pontuados, pontuações castanhoescuras, uniformemente densas. Ângulos apicais agudos e fortemente produzidos. Superfície ventral do abdome de coloração semelhante ao tórax, sendo que a faixa castanhoclara abrange quase todo o abdome até próximo aos espiráculos, nesta região com uma série contínua de máculas calosas semelhantes a S. costalis (Fig. 109). Espinho mediano do $3^{\circ}$ segmento abdominal agudo. Pernas de coloração castanho-clara a castanho-escura com raras pontuações castanhas nos fêmures, tarsos castanhos.
Genitália. Pigóforo globoso, taça genital levemente pontuada ventralmente, pontuações ferrugíneas. Ângulos póstero-laterais em "U” aberto com a margem dorsal projetada num pequeno processo digitiforme enegrecido e voltado para o ápice dos parâmeros. Bordo dorsal côncavo, medianamente com 1+1 pequenos processos nos ângulos basais, em forma de abas largas, deprimidos dorso-ventralmente e com ápice enegrecido voltado para os parâmeros (Fig. 17). Bordo ventral em "V" aberto projetado medianamente provido por estrias transversais enegrecidas, e uma projeção digitiforme, negra a frente das estrias (Fig. 34). Décimo segmento, quadrangular, perpendicularmente disposto em relação ao plano sagital, amplamente exposto em vista dorsal e projetado ventralmente (Fig. 17). Parâmeros dispostos perpendicularmente ao plano sagital, largos, deprimidos lateralmente, com uma projeção situadas perpendicularmente ao ápice do parâmero e voltada para o bordo dorsal, abaixo desta projeção há alguns pêlos longos dispostos longitudinalmente. Superfície apical totalmente rugosa. Uma faixa negra, rugosa, percorre dorsalmente a projeção até o ápice (Fig. 49). Phallus. Vésica em tubo cilíndrico curto, com $1 / 3$ do comprimento da phallotheca. Processos da vésica lembrando um chapéu bávaro, com um par de projeções laminares anteriores, deprimidas lateralmente, menos volumosas e um par de expansões laminares posteriores mais volumosas envolvendo 2/3 basais do ductus seminis distalis. Gonoporo secundário em calha (Fig. 64). 
Tabela I. Matriz de dados para o grupo externo e as espécies do gênero Serdia. A ordem dos caracteres é a mesma apresentada no texto. $0=$ estado plesiomórfico; 1, 2, 3 = estados apomórficos; ? = não comparado.

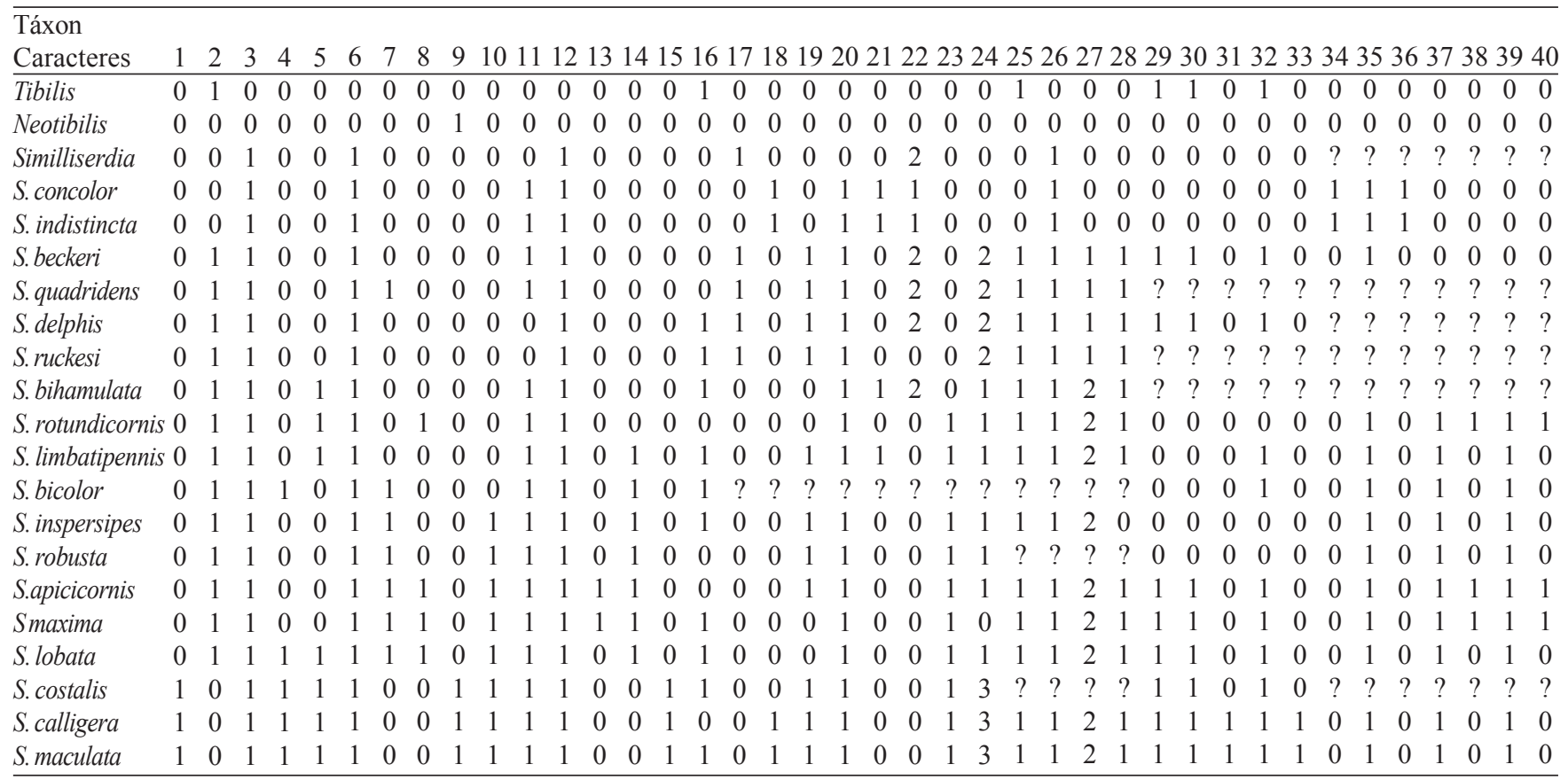

Fêmea semelhante ao macho. Medidas $(n=43)$. Comprimento total 14,9 (15,9-13,9) 0,2; largura abdominal 8,3 $(8,9-7,5) 0,1$; comprimento da cabeça $2,0(2,8-1,7) 0,1$; largura da cabeça $3,0(3,2-2,5) 0,1$; comprimento dos artículos antenais I $0,5(0,7-0,3) 0,1$; II $0,3(0,4-0,2) 0,1$; III $1,8(2,0-1,5) 0,1$; IV 1,4 $(1,5-0,6) 0,2 ; \mathrm{V} \mathrm{1,6}(1,7-1,4) 0,2$; comprimento do pronoto 3,7 $(4,0-3,3) 0,1$; largura anterior do pronoto $3,3(3,7-3,0) 0,1$; largura posterior do pronoto $8,1(8,6-7,5) 0,1$; comprimento do escutelo $6,2(6,9-5,7) 0,1$; largura do escutelo 4,9 (5,2-4,5) 0,1.

Genitália. Superfície das placas genitais moderadamente pontuada, pontuações castanho-claras. Sétimo segmento com margem posterior côncava sobre os gonocoxitos 8 . Laterotergitos 8 triangulares, subiguais em comprimento em relação aos laterotergitos 9, bordo posterior ponteagudo. Laterotergitos 9 sub-retangulares com ápice truncado e ultrapassando nitidamente a banda que une dorsalmente os laterotergitos 8. Gonocoxitos 8 subtriangulares, entumescidos, de comprimento longitudinal subigual aos laterotergitos 9, ápice suavemente convexos, ângulos laterais externos projetados num pequeno espinho; bordos suturais paralelos em toda a sua extensão (Fig. 81). Décimo segmento quadrangular. Gonapófises 9 com espessamento da íntima vaginal esclerotizado em anel incompleto. Chittinelipsen situadas lateralmente ao espessamento da íntima vaginal. Comprimento do ductus receptaculi na região anterior a área vesicular com o dobro da região posterior a mesma área. Cristas anulares anterior e posterior convergentes, pars intermedialis ovalada. Capsula seminalis arredondada com três dentes longos, recurvados ultrapassando a crista anular anterior em
1/3 do seu comprimento e todos surgindo na porção médioapical (Fig. 95).

Distribuição. Brasil: Rio de Janeiro, Paraná, Santa Catarina e Rio Grande do Sul.

Material examinado. Holótipo macho, com as etiquetas: a) Brasil; b) F. Sahlb; c) Typus. (NHRS). BRASIL. Rio de Janeiro: Itatiaia, macho, XI-1959, W. Zikan leg. (MNRJ); Paraná: Ponta Grossa (Vila Velha), Reserva IAPAR, Br.376, fêmea, 11-IV-1988, Lev. Ent. PROFAUPAR (DZUP); Ponta Grossa (Vila Velha), Reserva IAPAR, Br.376, fêmea, 23-V-1988, Lev. Ent. PROFAUPAR (DZUP); Ponta Grossa (Vila Velha), Reserva IAPAR, fêmea, 08-VI-1987, Lev. Ent. PROFAUPAR (DZUP); São José dos Pinhais, Serra do Mar, Br. 277, Km 54, lâmpada, macho, 02-I-1987, Lev. Ent. PROFAUPAR, (DZUP); Campo Tenente, 2 machos, 21-I-1974, Becker, Mielke leg., (DZUP); Salto Osório, fêmea, 23-I-1974, coll. MRCN no 8803, J.G.-Vieira leg. (MCNZ); Santa Catarina: Florianópolis, fêmea, I-1956, coll. MRCN n 3581, Pe. Buck leg., (MCNZ); Nova Teutônia, fêmea, I-1939, Fritz Plaumann (DARC); Nova Teutônia, $27^{\circ} 11^{\prime} \mathrm{B} 52^{\circ} 23^{\prime} \mathrm{L}, 300-500 \mathrm{~m}$, fêmea, 30-IX-1962,

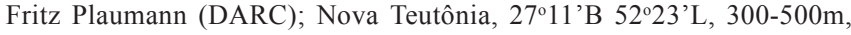
fêmea, 28-XII-1962, Fritz Plaumann (DARC); Nova Teutônia, $27^{\circ} 11^{\prime}$ B $52^{\circ} 23^{\prime} \mathrm{L}, 300-500 \mathrm{~m}$, macho, 17-IV-1966, Fritz Plaumann (DARC); Nova Teutônia, $27^{\circ} 11^{\prime} \mathrm{B} 52^{\circ} 23^{\prime} \mathrm{L}, 300-500 \mathrm{~m}$, macho e fêmea, 18 IV01966, Fritz Plaumann (DARC); Nova Teutônia, $27^{\circ} 11^{\prime} \mathrm{B} 52^{\circ} 23^{\prime} \mathrm{L}$, 300-500m, 3 fêmeas IV-1966, F. Plaumann leg. (UFRG); Nova Teutônia, $27^{\circ} 11^{\prime} \mathrm{B} 52^{\circ} 23^{\prime} \mathrm{L}, 300-500 \mathrm{~m}, 2$ machos e 2 fêmeas, Fritz Plaumann

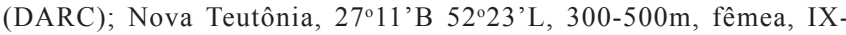
1966, F. Plaumann leg. (MZSP); Nova Teutônia, $27^{\circ} 11^{\prime} \mathrm{B} 52^{\circ} 23^{\prime} \mathrm{L}$, 300-500m, macho e fêmea, 17-II-1967, F. Plaumann leg., (DARC); Nova Teutônia, $27^{\circ} 11^{\prime} \mathrm{B} 52^{\circ} 23^{\prime} \mathrm{L}, 300-500 \mathrm{~m}$, fêmea, III-1968, F.

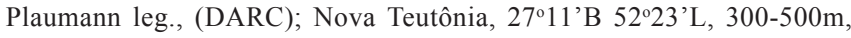
fêmea, XII-1972, F. Plaumann leg., (DARC); Nova Teutônia, 27¹1'B $52^{\circ} 23^{\prime}$ L, 300-500m, fêmea, XII-1973, F. Plaumann leg., (DARC); Nova Teutônia, $27^{\circ} 11^{\prime} \mathrm{B} 52^{\circ} 23^{\prime} \mathrm{L}, 300-500 \mathrm{~m}, 3$ machos e 8 fêmeas, I1974, F. Plaumann leg., (DARC); Nova Teutônia, 300-500m, 27º1 'B 
52²3'L, fêmea, III-1981, F. Plaumann (DZUP); Est. S. Catarina, C. Hansa, fêmea, II-1940, coll. MRCN n³580, coll. Anton Maller (MCNZ); Rio Grande do Sul: Torres, 14 machos e 17 fêmeas, II-1974, col MRCN n ${ }^{\text {os }} 8813,8815,8818,8819,8820,8822,8823,8824,8825$, $8826,8827,8828,8829,8830,8832,8833,8834,8835,8836,8837$, $8840,8841,8844,8845,8846,8847,8848,8849,8850,8851,16419$, Arno Lise leg. (MCNZ); Torres, 6 machos e 13 fêmeas, 15-XI-1974, coll. MRCN n ${ }^{\text {os }} 8720,8747,8749,8750,8753,8754,8755,8756$, $8757,8758,8759,8760,8762,8763,8764,8765,8766,8767$, Arno Lise leg. (MCNZ); Santa Maria, fêmea, 19-V-1972, armadilha de luz, D. Link (UFRG); Vila Oliva, em bambu, fêmea, 12-VII-1964, coll. MRCN no 3582 (MCNZ).

Comentários. O grupo formado por S. calligera $+S$. maculata tem sua monofilia sustentada por duas sinapomorfias, ápice dos laterotergitos 9 truncado e ângulos laterais externos dos gonocoxitos 8 com pequeno espinho e uma homoplasia, ápice do bordo dorsal do pigóforo com processo. Diferencia-se de S. maculata, morfologicamente, nos machos, pelos processos basais do bordo dorsal do pigóforo em forma de aba larga, deprimida dorso-ventralmente e com os ápices voltados para os parâmeros; nas fêmeas, pelo ápice dos gonocoxitos 8 suavemente convexos.

Serdia maculata, sp. nov. (Figs. 18, 35, 50, 65, 82, 94, 114)

Etimologia. Nome alusivo a presença de máculas calosas ventrais do abdome.

Macho. Medidas $(\mathrm{n}=2)$. Comprimento total 13,0(13,912,1)0,7; largura abdominal 7,1(7,4-6,9)0,2; comprimento da cabeça 1,8 ; largura da cabeça $2,7(2,8-2,6) 0,07$; comprimento dos artículos antenais I 0,6; II 0,9; III 1,3; IV 1,5; V 1,5; comprimento do pronoto $3,2(3,3-3,0) 0,1$; largura anterior do pronoto 3,2; largura posterior do pronoto $7,4(7,5-7,2) 0,1$; comprimento do escutelo $5,5(5,7-5,3) 0,1$; largura do escutelo 4,4(4,5-4,3)0,07.

Descrição. Forma ovalada, coloração castanho-clara com bandas submarginais no pronoto, uma mancha fraca mediana na metade anterior do escutelo e $1+1$ calo alaranjado nos ângulos basais do escutelo. Superfície do corpo com pontuações castanho-clara a castanho-escuras irregularmente distribuídas. Ventralmente o abdome é proeminentemente caloso lateralmente. Cabeça tão larga quanto longa, margem anteocular abruptamente sinuosa, larga e arredondada apicalmente, jugas mais longas que o clípeo e estreitamente contíguas apicalmente. Pontuações castanho-claras a ferrugíneas moderadamente densas e igualmente distribuídas, exceto na base onde estão dispostas em linhas longitudinais entre os ocelos, com uma pequena mancha negra atrás de cada ocelo. Antenas de coloração castanho-escuras do $1^{\circ}$ ao $4^{\circ}$ artículos, $1^{\circ}$ atingindo ou ultrapassando o ápice da cabeça, $3^{\circ}$ com um sulco mediano, $5^{\circ}$ totalmente amarelo-claro. Rostro atingindo o limite anterior da placa metasternal. Pronoto mais que duas vezes a largura ao nível dos úmeros que longo medianamente, ângulos umerais sub-retilíneos e não desenvolvidos, margens ântero-laterais largamente pálidas, pontuações pequenas e castanho-avermelhadas, castanho- escuras maiores e mais esparsas no restante. Cicatrizes concolores. Escutelo mais longo que largo na base, fóveas negras com $1+1$ grandes calos alaranjados circundados por pontuações castanho-escuras, estas irregularmente distribuídas e de tamanho diferenciado, sendo as de tamanho menor mais concentradas no terço apical e de coloração castanho-claras. Margem apical com 1+1 pequenas manchas castanho-escuras nas laterais. Hemiélitro com superfície de coloração castanho-clara, pontuações castanho-escuras irregularmente distribuídas e moderadamente densas. Célula discal ausente. Superfície torácica ventral de coloração castanho-amarelada na faixa mediana das pleuras, no restante é castanho-claro e esta separação de coloração é marcada por uma linha castanho-escura. Pontuações castanho-claras, menores e mais densas na faixa longitudinal castanho-clara e maiores e irregulares na faixa castanho-amarelada. Segmentos do conexivo expostos, castanho-amarelados densamente pontuados, pontuações concolores. Ângulos póstero-laterais agudos e fortemente apiculados. Superfície ventral abdominal de coloração semelhante ao tórax, sendo que a faixa castanhoamarelada abrange quase todo o abdome até próximo aos espiráculos, nesta região com uma série contínua de máculas calosas semelhante a S. costalis. Espinho mediano do terceiro segmento abdominal agudo (Fig. 114). Pernas de coloração castanho-clara a castanho-escura, destituída de pontuação, tarsos avermelhados.

Genitália. Pigóforo globoso, ventalmente pontuado, ângulos póstero-laterais em "U" estreito com uma pequena projeção digitiforme, voltada para o ápice dos parâmeros. Bordo dorsal côncavo com inconspícuo processo mediano nos ângulos basais, ápice voltado para os parâmeros (Fig. 18). Bordo ventral sinuoso em forma de "V" aberto, medianamente com estrias transversais enegrecidas (Fig. 35). Décimo segmento volumoso, de formato quadrangular, disposto perpendicularmente ao plano sagital (Fig. 18). Parâmeros largos, situados perpendicularmente ao plano sagital, deprimidos lateralmente, com uma projeção perpendicular ao ápice do parâmero, este projetado dorsalmente em ângulo agudo. Uma faixa rugosa e negra percorre dorsalmente a projeção até o ápice do parâmero (Fig. 50). Phallus. Vésica semelhante a $S$. calligera, também lembrando um chapéu bávaro, porém o par de expansões laminares anteriores envolvem totalmente o ductus seminis distalis. Gonoporo secundário arredondado (Fig. 65).

Fêmea semelhante ao macho. Medidas $(\mathrm{n}=2)$. Comprimento total 15,4 (15,6-15,1) 0,2; largura abdominal 7,4 (7,5-7,2) 0,14; comprimento da cabeça 2, 0 ; largura da cabeça 2,9 ; comprimento dos artículos antenais I 0,7; II 0,5; III 2,2; IV 1,9; V falta; comprimento do pronoto $3,3(3,5-3,3) 0,1$; largura anterior do pronoto $3,2(3,3-3,0) 0,2$; largura posterior do pronoto $7,7(7,9-$ $7,5) 0,2$; comprimento do escutelo $6,1(6,2-6,0) 0,1$; largura do escutelo 4,8 (5,0-4,5) 0,3.

Genitália. Superfície das placas genitais moderadamente pontuada, pontuações concolores. Sétimo segmento com margem posterior angulada sobre os gonocoxitos 8 . Laterotergitos 8 triangulares, subiguais em comprimento em 
relação aos laterotergitos 9 , bordo posteriores nitidamente ponteagudos. Laterotergito 9 com ápice truncado e ultrapassando nitidamente a banda que une dorsalmente os laterotergitos 8 . Gonocoxitos 8 subquadrangulares, entumescidos, de comprimento longitudinal subigual aos laterotergitos 9, ângulos laterais externos projetados num pequeníssimo espinho, margem posterior bissinuosa, bordos suturais paralelos em toda a sua extensão (Fig. 82). Gonocoxitos 9 com margem posterior côncava. Décimo segmento quadrangular. Gonapófise 9 com espessamento da íntima vaginal parcialmente esclerotizado e pouco visível, chittinelipsen situadas lateralmente ao espessamento da íntima vaginal. Comprimento do ductus receptaculi na região anterior a área vesicular é aproximadamente igual a região posterior a mesma área. Cristas anulares anterior e posterior convergentes, pars intermedialis ovalada. Capsula seminalis arredondada com três dentes longos, recurvos ultrapassando a crista anular anterior em $1 / 3$ do seu comprimento e todos surgindo na porção médio-apical (Fig. 94).

Distribuição. Brasil, Rio de Janeiro.

Holótipo macho. BRASIL. Rio de Janeiro: Itatiaia, 23-I-1948, col. J.F. Zikan (FIOC). Parátipos. BRASIL. Rio de Janeiro: Itatiaia, macho, 09-XII-1947, col. J.F. Zikan (FIOC); Itatiaia, fêmea, 06-I1948, col. J.F. Zikan (FIOC); Itatiaia, fêmea, 03-I-1948, col. J.F. Zikan (FIOC).

Comentários. S. maculata sp. nov. é grupo-irmão de $S$. calligera. Diferencia-se desta, morfologicamente, pelo padrão da genitália, nos machos, pelos processos inconspícuos junto aos ângulos basais do bordo dorsal do pigóforo, nas fêmeas pela margem posterior bissinuosa dos gonocoxitos 8 .

Agradecimentos. Aos curadores das coleções que enviaram materialtipo e exemplares para o desenvolvimento deste trabalho.

\section{REFERÊNCIAS}

Amorin, D. S. 1982. Classificação por sequenciação: Uma proposta para a denominação dos ramos retardados. Revista Brasileira de Zoologia 1: 1-9.

Amorin, D. S. 1997. Elementos Básicos de Sistemática Filogenética. São Paulo, Sociedade Brasileira de Entomologia. $314 \mathrm{p}$.

Arnett, R. H., G. A. Samuelson \& G. M. Nishida. 1993. The Insect and Spider Collections of the World. Gainesville, Saint Lucie. $316 \mathrm{p}$.

Barcellos, A. \& Grazia, J. 2003. Cladistic analysis and biogeography of Brachystethus Laporte (Heteroptera, Pentatomidae, Edessinae). Zootaxa 256: $1-14$

Becker, M. 1967. Sobre o gênero Serdia Stål, com a descrição de uma nova espécie (Hemiptera, Pentatomidae, Pentatominae). Revista Brasileira de Biologia 27: 85-104.

Becker, M. \& J. Grazia-Vieira. 1971. Contribuição ao conhecimento da Superfamília Pentatomoidea na Venezuela (Heteroptera). Iheringia, Série Zoologia (40): 3-26.

Buckup, L. 1961. Os pentatomídeos do Rio Grande do Sul (HemipteraHeteroptera-Pentatomidae). Iheringia, Série Zoologia (16): 124.

Campos, L. A. \& J. Grazia. (no prelo). Análise Cladística e Biogeografia de Ochlerini Rolston (Heteroptera: Pentatomidae). Iheringia,
Série Zoologia.

Cassis, G. \& G. F. Gross. 2002. Hemiptera-Heteroptera (Pentatomomorpha). In: W. W. K. Houston \& A. Wells (eds). Zoological Catalog of Australia, vol. 27.3 B. Melbourne, CSIRO Publishing, Australia xiv $+737 \mathrm{p}$.

Dupuis, C. 1955. Les genitalia des Hémiptères-Hétéroptères (genitalia externes des deux sexes, voies ectodermiques femeles). Mémoires du Muséum National D'Histoire Naturelle du Paris, n. s. sér A., Zoologie 6: 183-278.

Dupuis, C. 1970. Heteroptera, p. 190-208. In: S. L. Tuxen (ed.) Taxonomist's glossary of insects. Munksgaard-Copenhagen.

Eldredge, N. \& J. Cracraft. 1980. Phylogenetic patterns and evolutionary process. New York, Columbia University Press, $349 \mathrm{p}$.

Farris, J. S. 1988. Hennig 86 reference. Documentation for version 1.5. New York, Jefferson, $22 \mathrm{p}$.

Fortes, N. D. F. De \& J. Grazia. (1998) Um novo gênero e novas espécies de Pentatomini do Brasil (Heteroptera: Pentatomidae). Revista Brasileira de Zoologia 15: 867-874.

Froeschner, R. C. 1981. Elsiella, a new genus for Ebora plana Walker, 1867 (Hemiptera: Pentatomidae). Proceedings of the Entomological Society of Washington 83: 532-536.

Grazia, J. 1978. Revisão do gênero Dichelops Spinola, 1837 (Heteroptera, Pentatomidae, Pentatomini). Iheringia, Série Zoologia (53): 3-119.

Grazia, J. 1984. Pentatomini da Venezuela (Heteroptera, Pentatomidae). Anais da Sociedade Entomológica do Brasil 13: 71-81.

Grazia, J. 1997. Cladistic analysis of the Evoplitus genus group of Pentatomini (Heteroptera: Pentatomidae). Journal of Comparative Biology 2: 43-48.

Grazia, J. \& A. Barcellos, 1994. Neotibilis, um novo gênero de Pentatomini (Heteroptera). Iheringia, Série Zoologia (76): 5594.

Grazia, J.; N. D. F. De Fortes \& L. A. Campos. 1999. Superfamília Pentatomoidea, p. 101-112. In: Brandão, L.R. \& E. Cancello, (eds.). Biodiversidade do Estado de São Paulo, Brasil: síntese do conhecimento ao final do século XX, São Paulo, FAPESP,vol. 5

Hennig, W. 1966. Phylogenetic Systematics. Urbana, Univ. Illinois Press, $263 \mathrm{p}$.

International Comission on Zoological Nomenclature 1999. International Code of Zoological Nomenclature. $4^{\text {th }}$ ed London, Int. Trust for Zool. Nomenc. c/o The Natural History Museum, $306 \mathrm{p}$

Kirkaldy, G. W. 1909. Catalogue of the Hemiptera (Heteroptera). 1.Cimicidae. Berlin Felix L. Dames, XI+ 392 p.

Kormilev, N. A. 1955. Notas sobre Pentatomoidea neotropicales II (Hemiptera). Acta Scientifica de los Institutos de Investigación de San Miguel, 1: 3-15.

Kormilev, N. A. 1956. Notas sobre Pentatomoidea neotropicales IV, V (Hemiptera). Acta Scientifica de los Institutos de Investigación de San Miguel, 3: 1-12, 1 pl.; 4: 1-7.

Lethierry, L. \& G. Severin. 1893. Catalogue Général des Hémiptères - Pentatomidae 1. Bruxelles, $\mathrm{x}+286 \mathrm{p}$.

Link, D. \& J. Grazia-Vieira. 1983. Pentatomídeos capturados em armadilha de luz, em Santa Maria, RS, Brasil. Anais da Sociedade Entomológica do Brasil 12: 123-125.

Link, D. \& J. Grazia. 1987. Pentatomídeos da região central do Rio Grande do Sul. Anais da Sociedade Entomológica do Brasil 16: $115-129$.

Maddison, W. P.; M. J. Donogue \& D. R. Maddison. 1984. Outgroup analysis and parsimony. Systematic Zoology 33: 83-103.

Nixon, K. C. \& J. M Carpenter. 1993. On outgroups. Cladistics 9: $413-426$.

Packauskas, R. \& C. W. Schaefer. 1998. Revision of the Cyrtocoridae (Hemiptera: Pentatomoidea). Annals of Entomological Society of America 91: 363-386.

Rider, D. A. 2000. Stirotarsinae, new subfamily for Stirotarsus abnormis Bergroth (Heteroptera, Pentatomidae). Annals of Entomological Society of America 93: 802-806. 
Rolston, L. H.; F. J. D. Mcdonald \& D. B. Thomas Jr. 1980. A conspectus of Pentatomini genera of the Western Hemisphere Part 1 (Hemiptera: Pentatomidae). Journal of the New York Entomological Society 88: 120-132.

Ruckes, H. 1958a. New genera and species of neotropical Discocephaline and Halyine Pentatomids (Heteroptera, Pentatomidae). American Museum Novitates 1868: 1-27, Figs. $1-4$.

Ruckes, H. 1958b. Some new genera and species of tropical Pentatomids (Heteroptera). American Museum Novitates 1918: 1-15, Figs. $1-4$.

Schuh, R. T. \& J. A. Slater. 1995. True bugs of the world (Hemiptera: Heteroptera): classification and natural history. Ithaca, Cornell University Press, 336 p.

Stål, C. 1860. Bidrag till Rio Janeiro- traktens Hemipterfauna. Kongliga. Svenska Vetenskaps- Akademiens Handlingar 2: $1-84$.
Stål, C. 1867. Bidrag till Hemipterernas Systematik. Ofversigt af Kongliga Vetensk Akademiens Förhandlingar 24: 491-560.

Stål, C. 1872. Enumeratio Hemipterorum II. Kongliga. Svenska Vetenskaps- Akademiens Handlingar 10: p. 131.

Thomas Jr., D. B. \& L. H. Rolston. 1985. A revision of pentatomine genus Serdia Stål, 1860 (Pentatomidae: Hemiptera). Journal of the New York Entomological Society 93: 1165-1172.

Thomas Jr., D. B. \& T. R. Yonke. 1985. Cladistic analysis of zoogeography and polyploid evolution in the stinkbug genus Banasa Stål (Hemiptera: Pentatomidae). Annals of the Entomological Society of America 78: 855-862.

Watrous, L. E. \& Q. D. Wheeler. 1981. The out-group comparison method of character analysis. Systematic Zoology 30: 1-11.

Wiley, E. O. 1981. Phylogenetics. The theory and practice of phylogenetic systematics. New York, John Wiley \& Sons, XV + 439 p. 